Report No. 1245-AF

Industrial Sector Review of Afghanistan

June 1977

industral Profer:- Departme-nt

FOR OFFICIAL USE ONLY

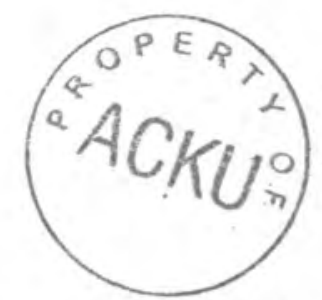




\section{CURRENCY EQUIVALENTS}

Free Market Average Rate 1974/75

US\$1

56.9 Af ghants

1 Afghan1

US\$0.0176

Note: The official rate of Afghanis 45 per dollar is used only for transactions with the IMF

\section{ACRONYMS}

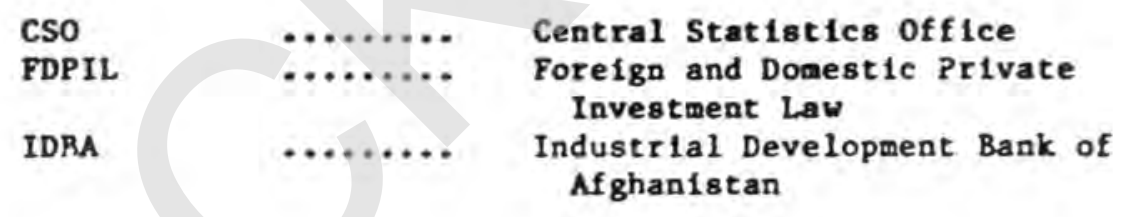

\section{YEARS}

The Afghan year 1s March 21 to March 20. The year 1355 s:urted on March 21, 1976 and 18 referred to as $1976 / 77$. 


\section{Area}

$635,000 \mathrm{~km}^{2}$

GNP per Cap1ta (1975) a/

$\$ 130$

Rate of growtb 1965-74

Labor Force $(1978 / 75)$

Agriculture

Hand 1 craft $s$

Manufactur Ing

Services

Construction and kining

Unallocated

Unemployed
Populacion $(1975 / 76)$

16.7 m11110n

of which urban: 2.4 mil110a

\section{M11110ng}

\begin{tabular}{l}
3.29 \\
0.31 \\
0.09 \\
0.41 \\
0.13 \\
0.70 \\
0.38 \\
\hline 5.31
\end{tabular}

Recorded Fore1an Trade in 1974/75 b/

Export f.o.b.

230.1

Flnal Industrial Products

24.2

of which: Carpets

(19.5)

Products for processing abroad

73.9

of which: Raw Cotton, Lint

and Waste

(34.7)

Hides, Skins, Furs

19.3

Licorice Root

7.1

Sheep Wool

5.8

Imports c.1.f.

242.4

Commercial Industrial Products

154.2

Monopoly Industrlal Products

11.8

Loan and Grant Financed

Industrial Products

$\underline{30.0}$

a/ World Bank At 1 as 1976

b/ See Annex A 
Page No.

SLMARY OF CONCLUSIONS AND RECOMMENDATIONS

$1-\nabla 1$

I.

IHDUSTRY IN THE AFGHAN ECONOMY.

The Present Position of industry.................

Conilderations of Comparative Alvantzge .........

Types of Industry with Growth Potentlal

The Seven Year Plan - Nature and Composit I

General Econonfe Criterla and the Plan ..........

Organization of Planning for Industrid

III. GESERAL ?ROBLEMS AND POLICIES FOR MORE RAPID

INDLSTRIAL DEVELOPMENT $\ldots \ldots \ldots \ldots \ldots \ldots \ldots \ldots \ldots$

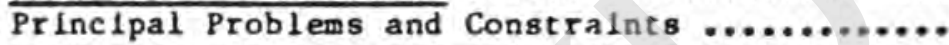

Problems of Management and Technical Sk111. ....

The Indirect $I_{a x}$ Systen.......................

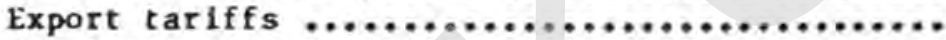

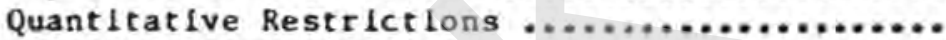

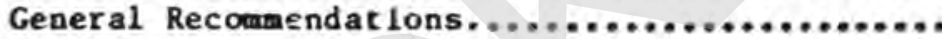

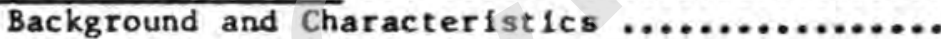

The Contral of Public Sector Industrles .........

Profitab111ty of Industrial Enterprises .........

Internal Management and Operat!snal Problens....

Government Control and Support of Private

Industry ................................

Flnancing and Other General Support ............. 


\section{TABLE OP CO:ITENTS}

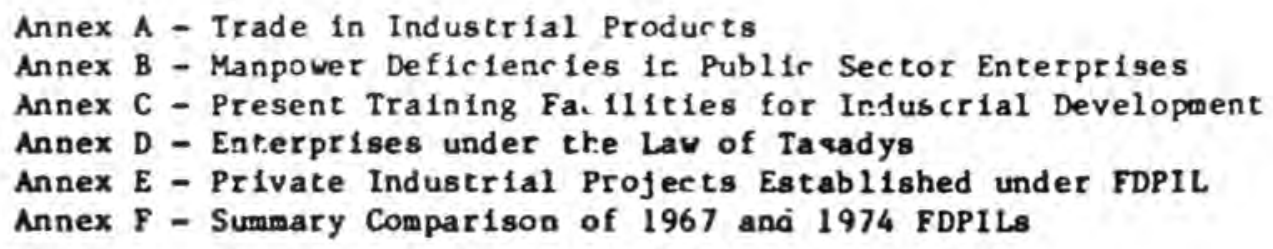

MAP

This report is based on the finfings of an industrial mission which visited Afghanistan in April 1976. The mission consisted of Messrs A. Edwards (Consultant, Chief of Mission), K.H. Inam (Bank), D. Madan (Consultant) and M Al-Ali (UNIDO-Bank C?). 
Industry in the Afghan Econozy

1. The 1ndustrial sector in Afghanis'an 18 still at an early stage of developeent, and 1 ts contribution to domestic employment and output is small compared to the country's size and resource endovment. Despite the early establishment of a few largar malafacturing units by private enterprise before World War II, and the nore recent emergence of a number of industrial ventures in the public sector, the bulk of Industridi employment is st11l largely confined to handicrafts and 3mall-scale manufacturing operat1ons. The latter also contribute more to domestic value of output and the export of 1ndustrial products than the organized larger-scale industries.

11. Due to the lack of adequate national accounts in Afghanistan and the scarcity of rellable statistical data, the relative position of industry can only be somewhat sketchily indicated. Official (CSO) data suggest thas out of a tota? labor force of over 5 million in 1974/75, some 300,000 were engaged In handicrafts, and organized manufacturing industries accounted for about 90,000 persons. Industrial employcent thus comprised less than 87 of the labor force. Handicrafts and small-scale industries contribute approxicately 8-10\% to GLP and mazufacturing and mining another 5-7z.

111. The early stage of industrial development in df ghanistan is also reflected in the country's foreign trade. In $1974 / 75$ only about $10 z$ of recesded exports were 1ndustrial products, essentfally carpers and other handicraft items. A further 327 of the $1974 / 75$ exports wer raw and intermediate products, which had undergone some siaple preliminary processing in Afghanistan. On the other hand, Industrlal products constitute the bulk of recorded imports, about $80 z$ in 1974/75. Eetails oz Afghanistan's recorded foreign trade in industrial procucts are shown in Annex $A$ of this report.

1v. Industrial employment in Nighanistan depends essentially on domestic raw materials, mainly cotton, wool, hides and skins, and fruits. The role of imported raw materials and intermediates has increased during the past 10-15 years, hovever, as manufacture of rayon, plastics and metal products has been developed. At the same time the use of some non-agricultural domestic raw materials for manufacture of cement, construction materials, nitrogeneous fertilizers, etc., has also been developed.

v. Substantial constraints work against any rapid broadening of the industrial sector in Afghanistan. Host of these are linked to the country's Income level, and to 1 ts landlocked situation and nountainous terrain. Transport is costly and slow, and the dowestic market is fractionated and craditional. :-aders and money lenders dominate the handicraft and smallscale industrild. There is no long-standing tradition in Afghanistan in managing large-scale organizations; there is also a scarcity of technical skills; aid the performance of existing industrial enterprises, particularly in the public sector, needs considerable improvement. On the other hand, 
Afghanistan offers favorable conditions for industry through comparatively low labor cost, modestly priced factory space and potential:y substantial supplies of agricultural raw materlals and mineral resources.

Development Planning for Industry

vi. The draft Seven-Year Plan, covering the pertod 1976/77-1982/83, reilects an increased emphasis on industrial expansion, notably through the establishment of relatively large import susbstituting industries based on domestic raw materials and a fev even larger capital-intensive projects that would process mineral resources for export. The latter would require advanced technologies and relatively long geatation. Public investment for Industry during the plar. period is tentatively estimated to amount to US\$674 million in 1975/76 prices; including mining projects, the total would rise to an estimated U3\$816 million. On an annual basis, this is almost three t1mes the volume of public sector investeent out lays in industry and mining in the past four years. Aro:ind $60 z$ of the envisaged public industrial investments are for teport-substitucion industries such as sugar, cotton, cement, fert1l1zers, and food. Over $20 \%$ is allocated for two large metallurgical projects, the Ainak copper smelter and the Hajigak 1 ron and steel profect, both of which would start operations only after the current plan period. The remainder of new public investments envisaged are for petroleum refining, pipelines, and Reological exploration. Detafls of planned public investments in industry and mining are shown in Tables 4-7 of the report (paras $2.4-2.9$ ).

vii. The Plan is essentially a seven-year public investment program. Little attertion has been devoted to private sector investment in industry; the Plan envisages private sector investment in industry to the extent of about US\$140 million over the seven-year period; but this is only an indicative goal in general teras and no spe if 1 c projects or breakdown by sub-sactors are mentioned in the Plan. Stall-scale industry and handicrafts have not attracted any consideration either.

viil. With respect to public sector investments in industry also, the underlying assumptions are largely tentative. For as much as $40 z$ of envisaged public sector investment, projects are still at ieasibility or prefeasibility study stages; and the economfc analysis necessary to establish their benefits to the econony has not yet been undertaken. Prima facie, project selection appears to be biased in favor of large, capital-intensive projects requiring modern technology but contributing relatively little to employment generation (paras. 2.16 and 2.17). It also appears that intersectoral inconsistencies in the Plan could adversely affect many of the larger public sector projects (paras. 2.18 to 2.20). On the whole, thers is a clear need to improve the procedures and quality of planning, project preparation and coordination for industrial development. In this context, 1t is particularly important so improve the 1 falson between the government departments that share direct control over industry (the Ministries of Mines and Industry, Commerce, Public Works, and Planning, anong others), and to rationalize their respective responsibilities. 


\section{Iax Folics}

1x. Except for the 1acentives provided to new private sector industries under the Foreign and Dosestic Private Injestment Law (FDPIL), fiscal policy is not really used as instrusent of industrial promotion. This is mainly due to the government's heavy dependence for revenue on indirect taxes, the structure of which, however, is unduly complex. Returns on darect taxes, mainly incose taxes, are of minor fiscal importance. Returns on corporate Income taxes could be expanded if accounting standards at company level can be improved and clear guidelines establlshed for tax assessments.

\section{Public Sector Industry}

$x$. The public sector has since the 1960's become increasingly involved in Industrial operations, and it contzols now, directly or indirectly, most of the corntry's larger manufacturing enterprises. This increasing involvement is partly the result of take-overs of afling or abanduned enterprises of the private sector and of the nationalization of banks, which maje the government a majority shareholder of some of the largest previously private manufacturing firms. Other public sector enterprises came into existence as the result of bilateral atd profects. The most 1mportant public sector enterprises are in the processing of cotton and wol, in construction materials, fertilizers and food products (1ncluding sugar, wich is a state monopoly).

x1. Government control of public sector enterprises is exercised in a variety of wiys; this makes effective coordination difitcult, and does not help the development of effective management functions at cnterprise level. Sone enterprises are controlled through majority shareholdings and representaticn on Boards of Directors: others are operated as branches of a ministry or under the adainistzative form of a Tasady. The iater is a blanket form of organization covering productive enterprises as well as government services and parastatai organizailons of all types. Altogether there are about 40 such enterprises, controlled by ten different ministries. The Minister concerned controls all essential operations of a Tasady, and there is only 11mited delegation $n^{*}$ management functions to the staff of the enterprise 1tself (para. 4.8). In spite of the fact that control 18 exercised at government rather than the enterprise level, individual enterprises in the same industicy operate in the main as separate entities rather than as a coordinated group.

x11. Peliable information on the financial performance of public sector enterprises is largely not avallable since accounting procedures have serlous defiviencies (paras. $4.15-4.17$ ) and some Tasadys are several years oehindhand in submitting accounts. On the whole 1t appears that public sector enterprises nake little, 1 f any, net contribution to the government budget. An exception is the Afghan Textile Company which accounts for much of the financial surplus of all public industrial enterprises. A tentative estimate places the annual profit of public sector industries in the order of US\$4 million (para. 4.17). At the technical level, operations of some public 
sector industries are reasonabiy sat 1 ifactory, het even these lack market orientation and the basic elegencs of forvard planning. Many existing public sector enterprises are -king below capacity, and priority should be given to resolving their problems. This is particularly important in view of the very substantial expans on of ptblic sector ladustrial activities envisaged for the current Seven-Year Plan.

\section{P:ivate Sector Industry}

x11. Little emphasis has been givin to private sector industry, and measures ia support of handicrafts and small-scale 1ndustrial operations have been ainimal. The capabilities of private sector entrepreneurs could be more effectively harnessed for pianned deve:opment if they were to be more fully recognized by the government. Past suppor: of private industry has been essentially 1 imited to f sscai incentives provided under the Foreign and Domestic Private Investment Law (FDPIL) as formulated in 1967 and improved in 1974 (For deta1ls of the FDPIL provisions see Chapter V). Unt1l mid-1974 the authorities had approved a total of 100 private industrial projects under the FDPIL. The projects envisaged an average original investment of about US\$210,000, and vere mainly 1mport-substitut1ng industries such as rayon weaving, plastic products iccluding footwear, and metal fabrication (para. 5.6). Most of the new entrepreneurs came from the trading class. In recent years. however, there has been a substanc1al decline in FDPIL approvals; only 14 new projects have recelved fi:al approval since 1974 (para. 5.8), and even of these few projects, some are not expected to be implement id.

xiv. There has been a notable deterioration of the climate for private investment in recent years. There is an apparent connection between this and the lack of a clearly defined role for private sector industry in Afghanistan's economy. The absance of a clear pollcy statement defining the spheres of activities that would be avallable to private entrepreneurs continues to delay the restoration of confidence, and has contributed to a widespread feeling in the private sectur that the government is not basically in favor of a larger role for private enterprise in industry. Although recent government statements have indicated its positive attitude to the private sector, fore specific measures are apparentily needed to generate confidence.

xv. The prevalling lnvestment climate has contributed to the fact that the Industrial Development Bank of Afghan1stan, which was founded in 1973, has not been able to provide any significant financial assistance to the private sectos (para. 5.20). Instead, activities of IDBA have concentrated on management and other technical support to private entrepreneurs, earning a good reputation in this respect. Paucity of managerial and technical skills in private industry and the absence of adequate training facilities, particularly for small enterprises, are amsig the major constraints to development of private 1ndustrial enterprises. Training in accountancy, production planning and marketing may, therefore, be an effective way of promoting private industrial activities. 
Ma1n Recommendations

rvi. Oulng to the scarcity of rellabie statistical dzta and the deficiencles in current accounting procedurea, the findings and recommendations made in this report are necessarily more general than specific. Also wat is sald about planning of 1ndustry ls largely based on the draft Seven-Year ilan and a profect 11s: made avallable to the mission.

\section{Planning and Coordination}

xv11. It 1s proposed that an Industrial Planning Unft be established to unify and strengthen the planning function for the industrial sector. This unit could be established winin the Ministry of Mines and Industry to take advantage of the fact that this ministry has statutory control over the most 1mportant industrial enterprises of the country; and it could billd its operations on the work already belng done by the UNIDO Industrial Services Profect. The proposed activities of the Unit would, after gradual bulld-up, include project 1dentification, participation in prefeasibility and feasibility studies, coordination of all planning efforts for industry, and $t r$ ing of Afghan staff in 1ndustrial planning techniques (para. 3.34). Fo: Untt to become successful in its activitles, the support and cooperation. receives from other ministries, specially the Ministry of Planning, wcul : be of great importance.

xviif. Improvement of statistical data is of key importance to ades: , planning for irdustrial development. To this end, it is suggested if . . work of the Central Statistical office be reorganized and priority $g^{\prime}$.' ' the elaboration of statistics on Industrial production and material of Industry (para. 3.35).

\section{Manpower Development}

xix. It is further proposed that a Management Develorment Center be established to cater primar1ly, but not solely, for public sector industry (para. 3.36). It should offer courses and training in enterprise management, accounting and financial management to appropriate levels of stafi. In deteraning the requirements for facilities and staff, account should be taken of existing institutions, particularly the ILO Training Project.

xx. In addition, the goverment should consider wider use of the services of a recognized firm or fires of accountants to establish proper accounting procedures for public enterprises and for auditing the accounts of these enterprises unt1l adequately trafned Afghan staff can assume these functions (para. 3.37).

\section{State Industrial Enterprises}

xxi. Public sector enterprises in industry should be given an appropriate structural and organizational frazework in which they can operate with a greater degree of management responsibility, specially for day-to-day operations 


$$
-\mathrm{vi}-
$$

(para. 4.30). Details of the future struc:ural and organizational set-up of public sector enterprises will have to he determined after careful study of the speci.ic conditions affezting these inductries in Afghanistan, and the relevant exferience gained abroad with different forms of state enterprisz organization.

xxil. Pending reorganizatis $\mathrm{n}$, effort; should be made tu improve accounting procedures and operational efficiencies at the enterprise level (para. 4.32).

\section{Private Sector Industry}

xxi11. In view of the importance, capabilities and potentlal of small-rcale and handicrafts industries in Afghanistan, it is essential to inftiate a systenatic program of support and development for them. It is suggested that the Afghan Handicrafts Pronotion Center, IDBA and other relevant government agencies should collaborate to develop handicraft sillls and technologies, encourage their development through better danagement of production and marketing, and channel financial assistance to them through appropriate agencies (para. 5.33).

xxiv. I a addition, a managenent consultancy operation should be estab!ished for private industry, to advise and assist in matters such a eppraisal of investment rrojects, operations, accountiag and financial problens, and mark?ting. These services zould be provided under IDBA's guidance and respunsibil'ry (para. 5.35). 


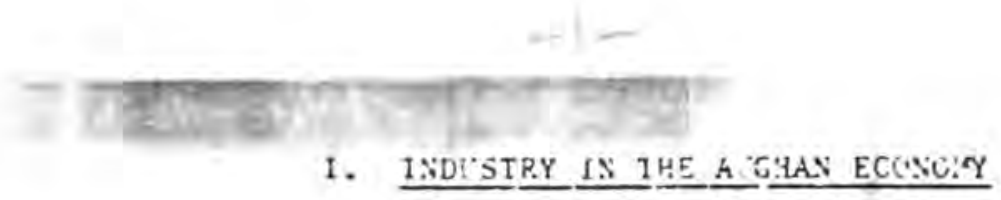

A. The Present Po.z" iun of Industry in Af ian stzan

1.1 For the gurpose of this report industry is defined to include ail pronessing ectivi-ies, on whazerer srale, but to exclude aining and 'tlities. Enterfrises rtht are contro:led by Government or fall ander the taw of racadvs are consalered public secto interprises. Private sectcr 1.t Hustry is coaprised of fnciustrfes approver under the Forefg= and DouestiPrfyate Inyestment Law (FOPIL), industries pslablished inder the Commercial Cocie vithort iDPIL 3 pors $\cdot a 1$, and all handicrait arti:itier.

1.2 Aitnough re; fable statistics are lacking it is cleaz that industry plays a ror:aicezably less inportant role in the domestic ecoumy of Afgha.ristan tha.1 in otter countries of cooparat le size and level of development. Ceniral Statistic = of ife data suggest that o:t of a total lobor, force of $5.3 i$ milition

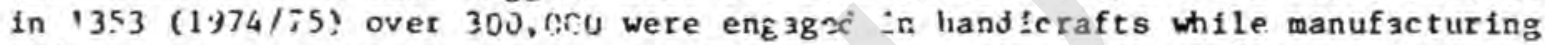
industres acrounter for about 90,000 persons. Industrial eatoywent thus comprised less th: $n$ 2\% si the labor force and handicrafts ipnroxirately $6 \%$.

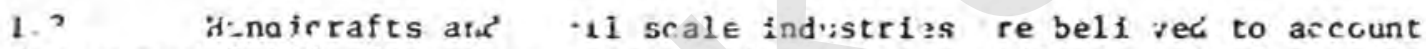
for arourd $8-10 \%$ of estis:- GDP in Afghanistan thile oro ized manutacturing and mining togetier contribute a further $3-7 \%$. These date .re apprcxinations only sius an edequate na inal accounts systew has not ye. been establi. ed.

1.4 in 175? (1974/75: :nal industrial products comprfsed only $10.5 \%$ of recorded expc-cs: neaily a 1 were handicraft items, notably c3-p?ts (8.5\% of the totall. A further $32 z$ of exports were raw and intarmeliate products for inciustrial frocessing biead; most of these had undergon slmple processing in Afghaisistar. I/ Details of Afghanistan'z recorded exports are shown in Arnex A. It shouid be poiated out thaz trade fiz ires are under-record ad as there is consider-bl - sauggling.

1.5 In $1974 / 75$ about $80 z$ of total recorded jaports were indust:ial products (Annex A: f faln, ebsclute f'gur s are under-recorded since many imports are jec-ared at :ess than their commercial value. Mly around 10-15z of recorded industrial prodict imports ar - for processiag in Afghatistan; textile yarns account for most of these. There if greater freedon to import Industria: goids - particularly consumer goods - iato Afghanistan than in many other conparable develnpirg countiles.

$1 /$ Due to a jan on textile exports none were recorded in i, 53 ; tn the past there have generally been significant exports of yarn and grey cloth. 
1.6 Import duties accointed for $58 z$ of government tax revenue and $j \rightarrow$ i of total government revenue in 1975/76; nearly all of these were duties on industrial products. Export duties on Industrial products are relatively unimportant as a source of goverment revenue.

1.7 A feature of the industrial sector in Afghanistan is the saall number of medium-sized industrial undertakings. A recent pilot study by the LXIDO Industrial Services Projert is: the Ministry of Mines and Industry fadicates a cotal employment of 13,700 in 16 publis sector industrial enter$p=$ ises - an ayerage of around 850 per enterprise; other publir secior industrial enterprises are typically rather soller but the average is still over 500. Table 1 gives some information on arge industrial establishments in Af ghanistan. At the other extreme, about 300,000 persons employed in handicrafts and swall-scale industries are spread over 80,000 establishments. In between are only about 100 industrial enterprises approved under the FDPIL (July 1975 position), which employ around 10,000 or 100 per enterprise; in prartire, the figure is lower as many are working well below rapacity.

I.8 Sketchy though these data on employment by size of enterprise are, they reflect firstly, the failure to convert any large part of the substantial handirrafts emoloyment into production on a semi-industrial or medium-sized srale; and secondly, the lack of many of the medium-sized import substitution fadustries which are present in other coaparable developing countries. 
Table 1 Main Industrial Establishments in Afghanistan

\begin{tabular}{|c|c|c|c|c|c|}
\hline & Name & Locat1on & Status & $\begin{array}{l}\text { Total } \\
\text { Employsent }\end{array}$ & $\begin{array}{c}\text { Ma1n } \\
\text { Products } \\
\end{array}$ \\
\hline 1. & $\begin{array}{l}\text { Afghan Tex- } \\
\text { tile Co. }\end{array}$ & $\begin{array}{l}\text { a) GuIbahar } \\
\text { b) Pul-1-Khumri } \\
\text { c) Jabul-1- } \\
\text { Seraj }\end{array}$ & $\begin{array}{l}\text { Ceapany with } \\
\text { banks holding } \\
\text { majority of shares } \\
\text { (now effectively } \\
\text { public sector) }\end{array}$ & $\begin{array}{l}4000 \underline{a} / \\
2250 \underline{a} / \\
\ldots \ldots\end{array}$ & $\begin{array}{l}\text { cotton yarns and } \\
\text { cloth, lncluding } \\
\text { finlshed products }\end{array}$ \\
\hline 2. & $\begin{array}{l}\text { Fertilizer } \\
\text { factory and } \\
\text { theraal power } \\
\text { plant }\end{array}$ & Mazar-i-Sharif & $\begin{array}{l}\text { Part of Ministry } \\
\text { of Mines } \\
\text { Industry }\end{array}$ & 3950 a/ & urea, electricity \\
\hline 3. & $\begin{array}{l}\text { Bagrami Tex- } \\
\text { tlle Factory }\end{array}$ & Kabul & Tasady & $2850 \underline{a} /$ & $\begin{array}{l}\text { cotton yarns and } \\
\text { cloth (including } \\
\text { finished products }\end{array}$ \\
\hline 4. & Splazar Co. & Kunduz & $\begin{array}{l}\text { Company - Govern. } \\
\text { Majority Shaze- } \\
\text { holding }\end{array}$ & 2250 a / & $\begin{array}{l}\text { ginned cotton, oi: } \\
\text { ollcake and soap }\end{array}$ \\
\hline 5. & $\begin{array}{l}\text { Prefabricated } \\
\text { Concrete Plant }\end{array}$ & Kabul & Tasady & 2200 a $/$ & $\begin{array}{l}\text { prefabricated } \\
\text { housing }\end{array}$ \\
\hline 6. & Jangalak & Kabul & $\begin{array}{l}\text { Company - Govern. } \\
\text { Mafority Share- } \\
\text { holding }\end{array}$ & 1200 a/ & $\begin{array}{l}\text { Eng ineer Ing } \\
\text { Workshops }\end{array}$ \\
\hline 7. & $\begin{array}{l}\text { Balkh ginning, } \\
\text { pressing and } \\
\text { oil extraction }\end{array}$ & $\begin{array}{l}\text { Mazar-1- } \\
\text { Sharif and } \\
\text { Balkh }\end{array}$ & Tasady & $1100 \underline{a} /$ & $\begin{array}{l}\text { ginned cotton } \\
\text { and oil }\end{array}$ \\
\hline 8. & Kabul silo & Kabul & $\begin{array}{l}\text { Part of Afghan } \\
\text { Food Dept.. Itself } \\
\text { a Tasady }\end{array}$ & 1000 by & Flour and Bread \\
\hline 9. & $\begin{array}{l}\text { Balich Tex- } \\
\text { tile Factory }\end{array}$ & Balkh & Tasady & 800 b/ & Cotton \\
\hline 10. & Cement Factory & Ghord & Tasady & $600 \underline{a} /$ & Cement \\
\hline 11. & $\begin{array}{l}\text { Woolen Indus- } \\
\text { tries, PuI1 } \\
\text { Chakri }\end{array}$ & Kabul & Tasady & $550 \underline{a} /$ & $\begin{array}{l}\text { wolen cloth, } \\
\text { carpers }\end{array}$ \\
\hline 12. & $\begin{array}{l}\text { Afghar. Lobil } \\
\text { Carpeatry }\end{array}$ & Kabul & Tasady & 500 b/ & $\begin{array}{l}\text { Furniture and } \\
\text { other tood } \\
\text { Products }\end{array}$ \\
\hline
\end{tabular}


Table 1 Main Industrial Establishments in Afghanfstan

(Continued)

\begin{tabular}{|c|c|c|c|c|c|c|}
\hline & Name & Location & Status & & $\begin{array}{l}\text { Total } \\
\text { Employment }\end{array}$ & $\begin{array}{c}\text { Kaln } \\
\text { Products }\end{array}$ \\
\hline 13. & $\begin{array}{l}\text { Ahu Leather } \\
\text { and Shoe } \\
\text { Factory }\end{array}$ & Kabul. & $\begin{array}{l}\text { Private } \\
\text { Company } \\
\text { Swlss) }\end{array}$ & $\begin{array}{l}\text { Sector } \\
(497\end{array}$ & $500 \mathrm{a} /$ & $\begin{array}{l}\text { Shoes, Fickled } \\
\text { Skins }\end{array}$ \\
\hline 14. & $\begin{array}{l}\text { Helmond } \\
\text { Cotton and } \\
\text { Vegetable } 011\end{array}$ & Lashkargah & Ta sady & & $500 \mathrm{~b} /$ & 011 and Soap \\
\hline 15. & $\begin{array}{l}\text { Baghlan Sugar } \\
\text { Factory }\end{array}$ & Baghlan & Pub1 ic & & $450 \mathrm{~b} /$ & Beet Sugar \\
\hline 16. & $\begin{array}{l}\text { Rabul Tex- } \\
\text { tile }\end{array}$ & Kabul & $\begin{array}{l}\text { Private } \\
\text { Company }\end{array}$ & Sector & $350 a /$ & $\begin{array}{l}\text { Syntbet1c } \\
\text { Fabrics }\end{array}$ \\
\hline 17. & $\begin{array}{l}\text { Nawrozi } \\
\text { Socks }\end{array}$ & Rabul & $\begin{array}{l}\text { Private } \\
\text { Company }\end{array}$ & Sector & $300 \mathrm{a} /$ & Socks \\
\hline 18. & Hoechst & Kabul & $\begin{array}{l}\text { Privace } \\
\text { Company } \\
\text { Cerman) }\end{array}$ & $\begin{array}{l}\text { Sector } \\
(482\end{array}$ & $250 \mathrm{a} /$ & $\begin{array}{l}\text { Pharea- } \\
\text { ceuticals }\end{array}$ \\
\hline 19. & $\begin{array}{l}\text { Watran } \\
\text { Plasties }\end{array}$ & Kabul & Private & Sector & $200 \mathrm{a} /$ & $\begin{array}{l}\text { Plastic } \\
\text { Shoes }\end{array}$ \\
\hline
\end{tabular}

af Data given to Mission on Visit to Establishment.

b/ Source: UNIDO Industrial Services Profect, Ministry of Mines and Industry. 
1.9 If. is is no $\mathrm{firm}$ information on the total value of private forelgn Investment i- ifghanlstan; Indeed, since several of the flrms are long-established, and accounts systems rately extend to the revaluation of assets, an adequate assessment would be impossible. In terms of original investment, foreign investment in FDPIL firms amounts to Afs 312 million (US\$5.5 m111ion) - see Annex E. Only two of the larger Industr'tl enterprises listed in Table 1 are noted as having substantlal forelgn sharenoldings; there are 19 smaller FDPIL industrial enterprises with forelgn interests - but the average foreign investment in these is only around Afs $8 \mathrm{mllli}$ ion per project. For a country of Afghanistan's population and size, In splte of low income per head, this level of forelgn investment is exceptionally small. The reasons probably lle to sone extent in the not very attractive investment climate (see paragraphs 5.8 and 5.31) but mainly is the freedom of import into Afghanistan. Under such circunstance, a forelgn firm usually prefers to serve a relatively small market by exports frca a larger manufacturing base than by establishing a saall-scale high cost production facility within that market.

1.10 Large and medium-sca'e industry In Afghanistan is 11nked primarily to the processing of local agricultural produce, whether for domestic use or for export rather than to import substitution. The most important non-handicraft sectors are cotton ginning and cotton textlles, food processing (notably flour milling, vegetable oils and sugar), and leather products (including pickled h(des). In the handicrafts sector, carpets, cloth, leather goods, pottery, metal-worklng and fur and skin clothing are predominant. This emphasls is a natural one. A Directory of Industrial Enterprises In Afghanistan, complled by the UNIDO Industrial Services Project In the MInIstry of Mines and Industry, IIsts the following sectoral breakdown of industry by number of enterprises: 


\section{Private Public Total}

Textiles

of which: cotton

wool

rayon/silk

thread

Knitted Products

Metal Products, Machinery

(Including Repairs)

of which: vehicle repair

Plast 1c Products

Leather Products and Shoes

Chrmicals and Pharmaceuticals

Food Products and Processing

of which: rais in processing

$$
\text { sausage casings }
$$

Cotton-ginning, 011 Extraction and Soap

Construct ton Materials

Print Ing

Ice Plants, Including Ice-Cream and cold stores

\section{7}

(19)

4

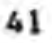

(-)

23

2

(6)

(1)

16

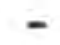

16

12

23

$(-)$

(1)

$\begin{array}{rrr}6 & 3 & 9 \\ 7 & 2 & 9 \\ 5 & 1 & 6 \\ \frac{8}{150} & \frac{-}{13} & -\frac{8}{163}\end{array}$

This classification does not distinguish between large and swall enterprises. Moreover, several of the "Industrles" would usually be considered service activities, whlle some enterprises which are not listed might reasonably be considered industrial. Four of the public sector Industries listed in Table 1, do not feature in this 1ist. Firms are in principle listed under their main, but not subsidiary, activities. In spite of all these qualifications, the classification gives some idea of the sectoral composition of industry. 
1.11 Adequate data on Industrlal output or exploysent by sector are lacklng. Central Statlstics offlce data covering apparently only public sector enterprises and FDPIL approved private firms gave for 1352 (1973/74) a total of 29,000 employed persons. Of the 29,000 employed persons $44 \%$ vere In textlles and cotton-ginning, $24 \%$ in food processing, while coal-mining and briquet, auto repairs and metal products, electricity, and printing and publishing accounted for $4-6 z$ each. It would appear that cSo industrial output data have a simllar coverage. It is evident that many industrles operating in small Individual units are seriously underrepresented In of $i c$ lal statistlcs (examples are bricks, woden buliding components, furniture, leather products, and cooking pots and utensils).

1.12 Although there are deflciencles in both production and trade statistics, it is clear that the great majority of clothing needs are produced elther in households or on a handicrafts basls; buflding materlals and components, and furnlture are predominantly on a handicrafts or very small Industrlal basis; cooking and tableware, household utensils, and all types of hardware are almost all produced either on a handicrafts basls or are Imported; and, drled frults apart, the processed foodstuffs industry is small. Even considering the low Income per head in Afghanistan, In relation to population, there is a lack of common import substitution Industrles. Paragraphs 1.24 and 1.28 discuss types of Industry in which there appear to be greater opportunities for developent.

1.13 In spite of the emphasis on processing of local agricultural produce, an Important proportion of this is st 111 exported, either unprocessed or having undergone only very simple processing. Raw cotton and 1 int and waste, wol, hides, skins and furs, licorice root, and ofl seeds and ofl seed flour and meal, are the most important Items.

1.14 Handicrafts and small-scale Industry are spread throughout the country, :hough carpet-weaving is predominantly in the North and west. FDPIL-approved private projects are, however, heavily concentrated in the Kabul area (figures in Annex F suggest that $86 z$ of investment is there, while no other city listed showed shares of over $4 z$ ). Public sector Industry is more widely spread as appears froa Table 1, but this follows from Its rav naterlal processing character.

\section{B. Considerations of Comparat Ive Advantage}

1.15 The sectors of industry which any country seeks to develop have to be those wich emphasize its economic advantages and minimize its economic disadvantages. Probably the largest single advantage wich Afghanistan enjoys is its comparatively low labor cost. In public sector industrles the monthly vage for an unskilled worker starts at around Afs 900 (US\$15). The average vage for all workers, both skilled and unskilled, is estimated at around Afs 1700 (US\$30). To this should be added between $20 \%$ to $40 \%$ for other vage cost elements, including usually a substdfzed allowance of flour, free lunch, transport to and from work, and medlcal care. Average costs vary according 
to the type of industry involved and the skilled/unskilled mix. Wages in Kabul appear only iractionally higher than elsewhere. The non-wage elements are generally higher in large firms developed under private enterprise, than in those which have been public sector from the beginning. Wage rates in the larger private industrial firms are generally similar to those in the public sector (though there is a wider d1vergenre between the best and the worst); non-wage elements are typira:i; less generous, though. In small industry and handirrafts, as in other sectors of the eronomy, vage ccsts are far lower. Although the prevailing low ajor rosts in industry have to be seen in the context of the predominance of unskilled labor and the resulting lower levels of produrtivity. It has been observed by the mission that Afghan workers are capable of achieving adequate rates of productivity.

1.16 At preseat the great majority of industry in Afghanistan purchases elertric power at ifs 1 per kwh (US\$0.02) irrespertive of amounts used. 1 I Power rates were fixed 20 years ago and are below the cost of supply $2 /$. The goverment has now agreed, pending the establishment of a new tariff system to an average increase of at least 20z. Even after this $10=$ rease, the normal industrial rate is unlikely to be murh above Afs 1.20 per kwh. It should be pointed out, however, that several existing industries have established the1r own power generating fariilies, generally on a stand-by basis, in view of the absence of assured supplies from the National Pover Authority, in periods of drought.

1.17 Factory space is modest in cost. A 525 square meter serviced factory on a 2500 square meter plot in the new Kabul industrial park is to +rost around Afs 3425 per square thater (LS\$60) to purchase on attractive terms (see paragraph 5.26), and elsewhere Afs 2500-3000 per square meter is noral for fartory spare. Water is also relatively inexpensive. In the Mazar-i-Sharif area, natural gas could be made available for process heat, and there are also several coal deposits in the North of the country. Diesel oll sells in Kabul at Afs 8000 (US\$141) per ton. Finally Afghanistan can make ava1lable to 1ts Industry substantial supplies of a 1 imited range of rav materials at prires which are competitive in relation to quality. These include: cotton, wool, hides and skins, various fruits, natural gas, and salt. There are mineral resources, but in many rases it is not yet proven whether they can be eronomically exploited and soid to local industry at prices wich would give that 1ndustry comparative advantage. It is evident that considerably more needs to be known about the avaflability of these resources as well as on other conditions of industrial produrtion before industrial opportunities can be established with an adequate degree of rertainty.

1/ This is the rate throughout the greater Kabul and Gulbahar area, in Pul-1-Khumri, Kunduz, and Jalalabad; in the Mazar-i-Sharif arca the rate is Afs 1.5 per kwt., in the Kandahar area $1 \mathrm{t}$ if Afs 1.87 per $\mathrm{kwh}$, while In most other areas with elertririty it is Afs 5 per kwh. Rates depend on the system of power generation.

2f See World Bank Ipprafsal of a Power Profect in Afghanistan, April, 1976 Report No. $1140-A F$. 
1.18 te dre a rimber of disadvantages which industry has to ove:rome

in tf ghti... 8 . These include: the lark of an industrial tradition, and consequent: Llic lark of vanagement and terhniral skflls, and the high rost and slowness of transport. To these "natural" problems should be added the fart that the policv eavironnent in Afghanistan has put industry at a comparative disadvantage.

1.19 Afghanistan's historical role as a nation of traders has stemmed from its geographiral position and its mountainous terrain. Its traders have never diversified into manufarturing on any significant scale, party berause they have been too small, and partly berause past governent policles made trade a nore profitable outlet for their activities. There are feu Afghans with the terhniral or tanagement skills wirh modern industry demands. This problem is disrussed further in Chapter III, paragraphs 3.3 to 3.10 .

1.20 The other basic disadvantage stich has to be overcone is that of transport rost and tise. At present a high proportion of both exports and imports move $v i a$ the USSR. It rosts USS 120 per ton for trans-shipment of parkaged ronsignments to Lon on, or tS\$90 per ton for raisins in bulk. But slowness and unreliability of transport are often eren more serious problems than the rost. Iransport throigh the USSR somizimes takes up to six months. This makes it impossible to guarantee export deliveries, and afferts the prire received. It also inposes an additiotal financing cost. On the import side, exreptionally large storks have to be held in Afghanistan, creating another financing burden. Alnost every industrial undertaking the mission visited hel? around one year's storks of spare parts and imported chemirals used in production rocesses. Large stocks are also held, for instance, of imported rayon yarns. Moreover, nany enterprises have capital and labor tied up in marnine tools used on an intermittent basis to nanufacture spare parts not held in stock. Even with the exercise of considerable ingenuity by enterprises, it is not unusual for production to be interrupted for months at a time for lark of certain coponents or spares which cannot be made locally.

1.21 Within Afghanistan the lack of an adequate road transport system 1 imits the effective market, making it difficult for industry to sell its products in all parts of the country. Of course, the Afghan market is sall in any rase; the large geographical area over wich it is spread, 1ts division by mountain ranges and inadequate transport factlities make it smaller, in effect.

1.22 It has been suggested that another basic problem of industrialization in Afghanistan is a lark of private finds wirh can be mobilized for industrial investment. In the rontext of large srale industry, this is certainly true. But for a reasonable nueber of smaller projects, creating about 50 to 100 jobs earh, this is probably not true. General eronomir developments in Afghanistan in recent years - good harvests, reasonable export growth, and only 1 imited recorded import growth - point to the likelihood of there being considerable unmobllized private sector savings though $\mathrm{firm}$ evidence to demonstrate this 
is iacking. Is is evident that many small traders hold stocks worth up to tS\$100,000, yet have a snall turnover in terms of sales, daking prufits through big markups and capital appreciation of stock (this is nost obvinusly true of carpet traders) - and mostly because of the appreciation of the foghat. In econonic terws this capital is underutilized, and efforts sloulf inade to encourage it into more productive sectors of the econony. Pror interests are probably capable of generating quite significant fundse. Industrial development. However, what is frequently lacking is the Ullifingness of private Interests to assume the rIsks of an industrial enterprise. This is not suprising glven the rather 1 imlted experience that is available in the country in setting up and operatling a modern industrial plant. Fear of possible government interventions also has contributed to discourage the private sectors for invest ing in new industrlal ventures.

1.23 The weakness of the flnanclal sector makes it difficult to combine the savings of individuals into amounts large enough to finance fair-sized industrial developments. But neither lack of prlvate funds, nor the deflciencies in financial organization, appear to be a slgnificant constralnt on the creation cf smaller scale projects involving investments of up to perhaps Afs 20 million (US\$ 350,000 ) each.

\section{Iypes of Industry with Growth Potential}

1.24 It follows foos paragraphs 1.15 to 1.23 above, and the general ines of government policy, that the types of Industry fros the developaent of which Afghanistan could draw the greatest econom Ic bene its are those wich, ccobine as many as possible of the following characteristics:

(a) labot-intensive, rather than capital-Intensive;

(b) export industries based on the maximum ut 11 cation of Indigeneous agricultural and. materlal resources;

(c) inport substitution industries, based on local resources Introducing new products to Af ghan consumers;

(d) i=pott substitution industries, or industries based on imported resources, where the technologies involved are suitable for production for a limited market;

(e) industries which do not involve copplex technologies, for which sicills would have to be imrorted, and those that do not pose complex management problems;

(f) export industries, based on Afghanistan's internat lonal reputation for carpets (and to a lesser extent other handicrafts), hides and skins, and fruits and nuts: 
(8) Industries putting handlcraft production for local use on a more organized basis.

It may be noted that (a), (d), (e) and (g) above, are all characteristics normally associated with small ladustrial units. Other characteristics are typically not associated with units of any particular size.

1.25 The mission was able to draw on some work done by the Industrial Development Bank of Afghan1stan (IDPA), by the UNIDO Industrial Services Project, by Indian industrial estate advisors and by specialists in particular f1elds, to develop some general conclusions on types of industry which neet the criteria of paragraph 1.24 and which appear to be either totally absent in Afghanistan, or which exist there on an insufficient scale. These conelusions appear in paragraphs 1.27 to 1.28 .

1.26 IDBA has drawn up a 1ist of about 100 potent1al nanufacturing projects, most of them appearing suitable for small to medium-scale operations. of these 24 are in food and related industries; 17 in text1les and clothing, 13 in chemicals, plastics, and rubber; 10 in stone, clay and glass products; 8 are primary metal Industries and 10 are for metal products, simple machinery and electrical equipment. Many of the projects on the list would aim at substitut1on for signlficant 1mports 1nto Afghanistan. Many too, are industries wich are present in other developing countries of a similar economic size and at a similar stage of development. Huch the same applies to the more selective lists of possible projects prepared by other organizations, of which the most significant ones were drawn up by Indian industrial estate advisors.

1.27 Table 2 11sts a range of potential new industries which appear to warrant further investigation. The 11st is 11lustrative of types of new Industries, rather than comprehensive. It is based on the criteria noted 1n paragraph 1.24, taking into account in particular the statistics on recorded International trade, Afghanistan's main agricultural and rav material products, and minimum viable production technologies for a country of Af ghanistan's economic size and stage of development. It must be emphasized that these are not recommendations for new projects, but illustrative examples of types of projects, which would require detalled econoelc and rechnical study. The viability of many would, weover, be dependent on the creation of an appropriate investment climate.

1.28 From Table 2 it can be concluded that:

(a) A high proportion of the putential new industries 11sted are medium scale (to employ between 50 and 250 employees), rather than large-ticale or small scale. The subsectors Involved are also in most cases those that many vould consider sulted to private sector investment and management.

(b) Many of the industries are 11nked to Afghanistan's production of raw cotton, wol, and hides and skins. 
(c) There appears to be scope for a wide range of medium or small import substituting industries, particularly in ressect of clothing, footwear, plastic products, metal products and certain food producte.

(d) Sowe of the 1ndustries envisage increased local production of items for which Afghanistan now both exports che prime raw materials and 1mpotts the flafshed products, such as processed 0118 and text1les.

(e) Most of the export-oriented industries envisage increased local added value to Afghan raw materials, or put existing handicrafts production onto an industrial siale. 
Table 2 - I:lustrat1ve Examples of Potent1al Neu Industrles in Afghan1stan

I. Industries based primarily on import subst1tution, or processing of local produce for domestic use

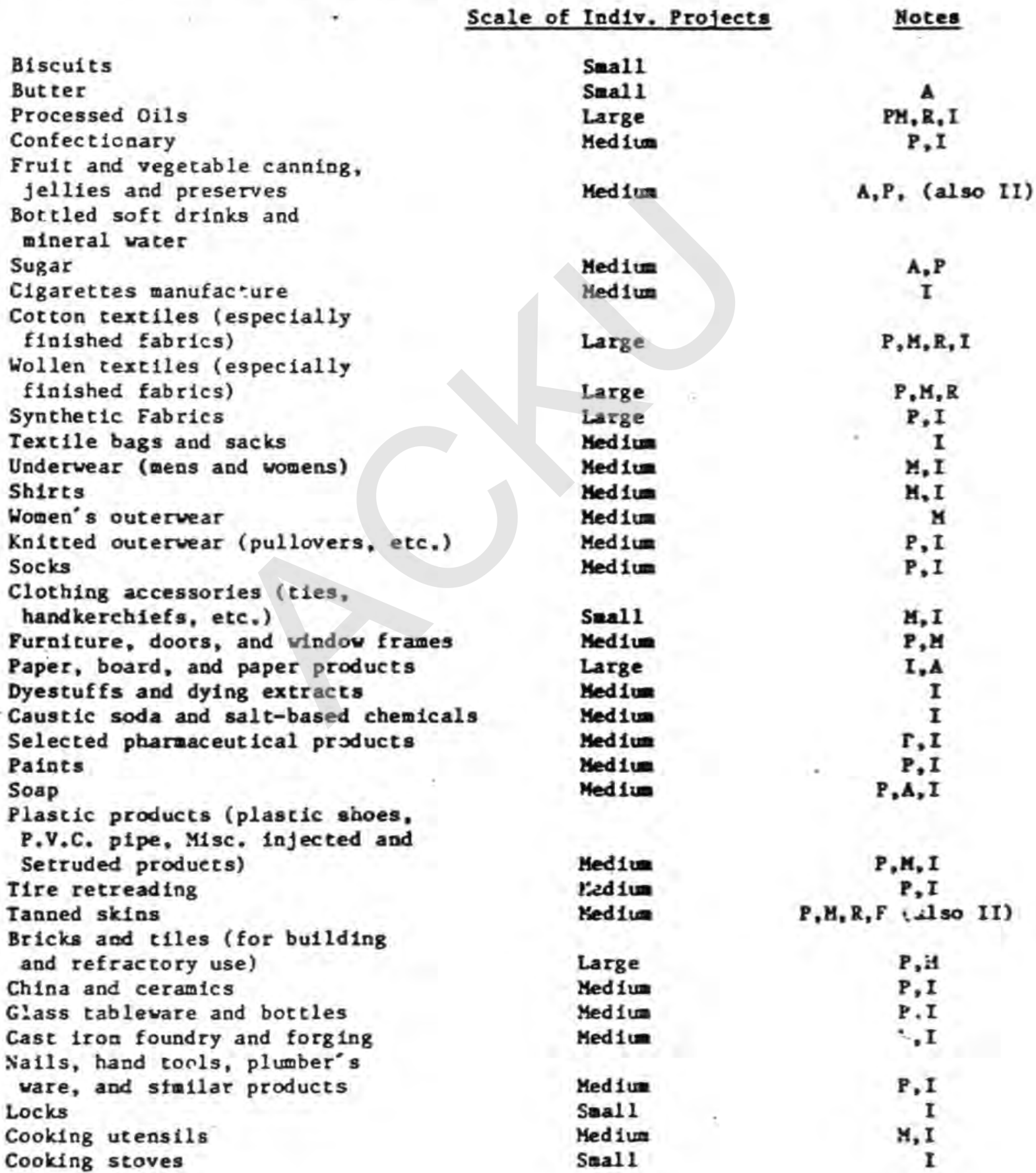


Table 2 (Continued)

Scale of Indiv. Praiects

Notes

Wire netting and fericing Primary battery manufacture

Smal 1

Medium

Small

Lighting fixtures and fittings

Sma11

Costume jewelry

II. Iudustries primarily for export

Canned or bottled frult and

vegetable juices and corcentrates Medium

olive preserves and ollve oil

Processed 11corice

Dried fruit processing

Carpets and rugs (non-handicraft)

Textile handicraft 1tems

Fr and leather garments

Leather shoes

Leather gloves, bags, purses,

belts, etc.

Med Ium

Yed 1um

Medium

Mediun

Med1um

Medium

Medium

$P, M, A$ (also I)

Sausage casings

Med fum

Medium

Medium

$$
\begin{gathered}
\mathbf{A} \\
P, \mathrm{R} \\
\mathrm{P}, \mathrm{M}, \mathrm{A}, \mathrm{E} \\
\mathrm{P}, \mathrm{M}, \mathrm{E} \\
\mathrm{E} \\
\mathrm{R} \\
\mathrm{P}, \mathrm{B} \\
\mathrm{M}, \mathrm{R} \\
\mathbf{P} \\
\mathrm{P}, \mathrm{M}, \mathrm{R}, \mathrm{E} \text { (also I) }
\end{gathered}
$$

Tanned skins

\section{Notes}

Ceneral: Several of these industries are of course given a high priority

in ine Plan. No reflection is intended on Plan projects which do not feature

in this 1llustrative 11st.

P - Industrial production already exists in Afghanistan, but additional facilities may be needed. Tor eany other ltens there is handicraft production,

I - Significant imports into Af chanistan at present.

R - 3iolficant exports of the necessary raw materials from Afghanistan; helce, possible scop for additional locally alded value.

A - Depends on agricuitural developaents.

M - More than one additional production facility may be needed. 


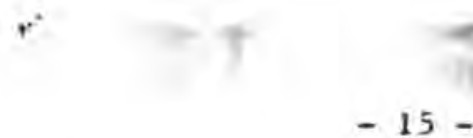

\section{Ii. IEVELOPMEN: PLANING FOR ISDESTRY}

\section{h. The Seven-Year Plan - Nature and Compos:-ion}

2.1 The figures quoted in this chapter are based on the draft Plan document received from the Government after the mission had completed its fleldwork.

2.2 In essence, the P'an for industr" appears $t$, be a collection of Individual public investment projects, linked ta principle as between sectors and to funds avallable. For the private sector there seems to be $11 t$ tle more than a statement of general expectations. Fiven the lack of information on all but the FDPIL private sector, ard indeed the abzence of rational accounts, this may be largely unavoldable: the statistical sols for adequate overall planning are lacking. iuwever, as privite sector industry, including hand1crafts, far exceeds public sector industry in ters of output and employnear. at present, the PIan should be regarded, in resper y? trdus:ry, as essentially a seven-year public investment progras, te ... Ig roughly $t$, the vider economic cuntext.

2.3 The Suven-Year Plan suggests total pubilic investzent experititure of Afs 38.4 billion (US\$674 million) in 1975/76 prsces for industrial development; 1ncluding mining expanditure 1 t is Afs 45.5 billion (Us $\$ 816$ millicil. The total, lncluding mining, vould represent $27 \%$ of che entire public Investment program of around Af 8 . Th bilion. Included in the Afs 46.5 billion are cariy-over projects from the orevious plan perlods (1.e. those already started), amounting to Afs 4.0 billion for industries and Afs 5.2 b11110 for mining. At an average annual expendituse of df 3.6 b11l1on, the total $1 ;$ in current price terms nearly chree times the volume achieved over the past 4 years. In rea' terms, the fncrease $1 \mathrm{~s}$, of csurse smaller, but the coo-avallab1l1ty of an approprlate deflator precludes the possibility of a measurement in terms of constant prices. What informacion does exist suggests, however, that relative to other countries, inflation in Afghanistan In recent years has been quite modest and it is clear that a very considerable acceleration in public industrial investment is planned. 
Iable 3 Public Sector Investment Expezd1tures, 1957/58 to $1975 / 76$

(In billion afghan1s, at current prices)

\begin{tabular}{|c|c|c|c|c|}
\hline $\begin{array}{l}\text { F1rst Plan } \\
1957 / 58- \\
1961 / 62\end{array}$ & $\begin{array}{l}\text { Second Plan } \\
1962 / 63- \\
1966 / 67\end{array}$ & $\begin{array}{l}\text { Third P1an } \\
1967 / 65- \\
1971 / 72\end{array}$ & $\begin{array}{l}\text { Annual Plans } \\
1972 / 73- \\
1975 / 75 \text { a/ }\end{array}$ & $\begin{array}{l}\text { Seven-Year Plan- } \\
1976 / 77 \text { - } \\
1982 / 83\end{array}$ \\
\hline$\cdots$ & $\cdots$ & 5.5 & 1.8 & 38.4 \\
\hline$\cdots$ & $\cdots$ & 3.7 & 5.4 c & 8.1 \\
\hline 2.6 & 8.4 & 9.2 & 7.2 & $\overline{46.5}$ \\
\hline
\end{tabular}

Note: The sub-sector breakdowns up to the Second Five-Year Plan are not avallable.

a/ The component figure for $1975 / 76$ is an estinate.

bf At $1975 / 76$ prices. Preliminary.

c/ Includes the Mazar-1-Sharif Fertilizer Plant.

Source: Ministry of Finance, Kabul

2.6 The public sector 1ndustrial 1nvestment plan envisages a rap1d ac:eleration during the first half of the Plan period, peaking 1n 1978/79 and 1979/80 (see Table 4); expenditure is expected to fall during the succeeding year, but plck up again oyer the next two years. Th1s pattern reflects both the completion of carry-over projects during the firgt half of the Plan period and the maturing of neu projects into active status after 1978/79. The Indicated phasing is based on the Government's presumption that ther- wll be a dramatic increase in the number of new projects being started. It also reflects fairly optimistic expectations as to the time required for nev projects to mature from the stage of conception to that of 1mplementation. Even the low $1976 / 77$ figure would represent an increase of about 150z, in current price terms, over estimated actual $1975 / 76$ expenditure.

\section{Table 4 Phasing of Public Sector Investment Expend1tures in Industry and Mining (In bill1ons Afs.)}

$\underline{\text { Years }}$

$1976 / 77$

$1977 / 78$

$1978 / 79$

$1979 / 80$

$1980 / 81$

$1981 / 82$

$1982 / 83$
Asount

$\begin{array}{r}4.3 \\ 7.3 \\ 8.3 \\ 8.3 \\ 5.7 \\ 5.9 \\ 6.7 \\ \hline \text { Total: }\end{array}$

7.3

8.3

5.7

5. 9

46.5

Source: Ministry of Planning, Kabul 
2.5 It 1 s envisaged that several of the projects to be undertaken durfing the present plan period would extend into the next plan period. Of major iaportance is $t^{\prime}$ - metallurgical sub-sector for which currently an investreat of Afs. 72.3 billion (US\$1.2 bil110n) is contemplated during the present and the next (1.e., 1983/84 to 1989/96) seven-year plan per1od, for the hoped-for iron and steel and copper smelting plants. Of this sum, only abuut Afs. 9.7 billion are envisaged durinz the current plan period. These very big projects are at a prelininary stage of study. Total investments expected to be carried forward into the next seven year plan period amount to Afs. 72.5 billion, of wich industries should constitute around Afs. 72.1 billion and wining about Afs. 0.4 billion.

2.6 In private sector industry an investment of about Af 8.8 b1111on (US\$140 ailifon) is envisaged. This total excludes very small firms (employing less than 5 people) and handicrafts. Investments by these do not feature in the PIan. It is expected that $60 z$ or more of the Afs. 8 billion would be self-financed. The expected private sector industrial investment of Afs. 1.I billion a year represents a very substantial increase over past rates of investzent and a short-fall on the implied annual rate seems inevitable in the earlier years. It vill require a cocsiderable improvement in the "climate" for private industrial investment, as perceived by private industrial investors.

2.7 As 1ndicated in paragraph 2.3 the plan estimates are based on 1975/76 price levels. The actual costs are, however, 11kely to be signiffcantly higher on account of escalation in domestic costs and costs of imported equiptient and services.

\section{Sectoral Composition}

2.8 The broad product composition of the Afs 46.5 billion of public investment planned in 1ndustry and mining is shown in Table 5. The areas of concentration are metallurgy (20.9 percent), cotton 8 inning and cotton textiles (12.0 percent), sugar ( 13.3 perceut), cement ( 7.7 percent), fert1l1zers ( 7.5 percent) and food industries ( 4.8 percent). Detalls on project composition are shown in Table 6, whle Table 7 shows the resulting increases in capacity by sector. 
Table 5: Product Compos1tion of Public Sector Investments in the Industry and Mining Sector a/ (In billion Afs.)
A. Industries
Carry-Over
Sew Total
(z of Total)
1. Cotton:
a. Ginning
b. Textiles
2. Woolen Textiles
3. Sugar
4. Cement
5. Fert1lizers
6. Mach1nery and Equipwent
7. Metallurgy
8. Food Industries
9. Other Chemicals
10. Paper
11. Others b/

$$
\text { Sub-total }
$$
0.8
0.1
$-$
$-$
0.7
-
-
0.1
-
-
2.3
2.1
2.7
0.4
6.2
3.6
2.8
1.7
9.7
2. 2
0.7
0.3
$\frac{2.0}{34.4}$
2.1
3.5
0.5
6.2
3.6
3.5
1.7
9.7
2.3
0.7
0.3
$\frac{4.3}{38.4}$
4.5
7.5
1. 0
13. 3
7.7
7.5
3.7
20.9
4.8
1.5
0.9
9.2

\section{B. Mining}

12. Coal

13. Natural Gas Pipeline

14. Others c/

$\begin{array}{lcccc} & - & 1.4 & 1.4 & 3.0 \\ & \overline{5.2} & 1.0 & 1.0 & 2.2 \\ \text { Sub-total } & \frac{0.5}{5.2} & \underline{5.9} & \underline{5.1} & \frac{12.3}{17.5} \\ \text { GRAND TOTAL } & 9.2 & \underline{3.3} & \underline{\underline{46.5}} & 100.0\end{array}$

aㅢ Prelininary.

bf Includes gas de-sulphurization plant.

cf Mainly exploration and surveys.

Source: M1n1stry of Planning, Kabul 
Table 6: Project Composition by Major Sub-sectors

(Data based on preliminary plan dccument)

$+\infty$

Sub-sectors/Projects

Amount

Annual Capacity

Coapletion Date

(In Af s.m.)

1. Cotton Text1le

a. Herat

b. Extension to

Balkh

c. Kunduz

d. Kandahar

e. Extension of

Pul-1-Kume I

Sub-Total
570.0

272.0

679.0

1710.0

266.0

3497.0

2. Cotton Ginning and Pressing

a. Extension of Balkh Ginning Plant

b. Kunduz I

c. Kunduz II

d. Badghis 1/

e. Extension to Helmond Ginning Plant 21 Sub-Total

3. Sugar
a. Replacesent and extension at Baghlan
b. Herat
c. Jala labad

2055.0

2055.0

2055.0

$12.0 \mathrm{~m} 111$ lon neters

$1978 / 79$

11.5 million meters

$1976 / 77$

40.0 million meters $1980 / 81$

40.0 mil11on meters $1978 / 79$

456.0

15.0 thousand tons

$1981 / 82$

453.0

15.0 thousand tons

$1979 / 80$

453.0

15.0 thousand tons

$1982 / 83$

5.5 thousand tons

$1978 / 79$

489.0

10.0 thousand tons

$1978 / 79$

2096.0

\section{Sub-Total}

6165.0

1f Actual cost estimates for the Badghls Ginning Plant amount ro Afs. 217 allilon capltal cost, plus a peak working capltal requirement of Afs. 274 million. The capac1ty will be 4,340 tons of ginned cotton $(14,000$ tons of seed cotton) per years.

2/ The capacity increase is actually estimated at 14,750 tons of ginned cotton $(47,600$ tons of seed cotton) per year. 
Table 6: Project Composition by Major Sub-sectors (Continued)

4. Cement

a. Kandahar

2180.0

480.0 thousand tons

$1979 / 80$

b. Herat

1420.0

210.0 thousand tons

$1978 / 79$

Sub-Total

3600.0

5. Fertilizers

a. Power turbine and auxillary

facilfties at the

existing Plant 700.0

$1978 / 79$

b. Second Fertilizer

Plant

$\frac{2800.0}{3500.0}$

300.0 thousand tons

$1984 / 85$

6. Other Chemicals

(location uncertain)

700.0

20.0 thousand tons

$1981 / 82$

7. Metallurgy

a. Ainak ropper) smelter )

b. Hajigak Iron)

9700.0 Not knom

Not known and Steel,

8. Miscellaneous

a. Petroleum

Refining

810.0

200.0 thousand tons

$1979 / 80$

b. Tanneries at

Herat and Ghazni

410.0

600.0 thousand tons

$1979 / 80$

c. Gas desulphurization plant (Replacement)

1000.0

-

$1979 / 80$

d. Food Industries 2300.0

e. Geologiral Exploration and Surveys

5800.0

f. Others

$\frac{6922.0}{17242.0}$

Sub-Total

GRAND IOTAL $\quad 46500.0$

Source: Ministry of Planning, Kabul 
Table 7: Annual Capac1ty in Major Public Secror Industries

A. Industry

$\underline{1975 / 76} \quad \underline{1982 / 83}$ Increase (z)

1. Cotton

a. Ginning (1000 tons)

b. Textiles (million meters)

2. Woolen Text1les (1000 meters)

3. Sugar (1000 tons)

4. Cement ( 1000 tons)

5. Fert1lizers ( 1000 tons)

6. Petroleum refining (1000 tons)

7. Metallurgy b/

B. Mining

8. Coal (1000 tons)

9. Natural Gas

(B1llion cubic meters) cf

$\begin{array}{rrl}60 & 115 & 91.7 \\ 100 & 200 & 100.0 \\ 270 \text { af } & 770 & 185.2 \\ 11 & 81 & 636.4 \\ 160 & 870 & 443.8 \\ 105 & 105 & - \\ - & 200 & \text { 1nf. } \\ - & - & -\end{array}$

91.7

85. 2

636.4

-

-

$350 \quad 105.9$

$3.13 .1=$

af Total installed capacity 600 thousand tons. The figure above represents the current capacity $11 \mathrm{mit}$.

b/ Refers to copper and 1ron ore and steel-making; no production is expected by $1982 / 83$.

cf Proposed 1nvestment is for balancing and modernization of existing equipment.

2.9 It w11 be observed that wile many planned investments are related to specific projects in known locations (some of them for plant modernization or replacement), large sums are envisaged for the st11l very tentative plans of the copper smelter, the iron and steel plant, for geological work in connection with these, as well as for a second fertilizer plant and fer a caustic soda plant. Indeed as much as 407 of the total investment might be regarded as tentative. This is, of course, unavoidable in any plan covering a sevenyear period. Though ent1rely new projects may come up during the plan period, it implies that the very b1g increase envisaged in public sector investment in the Plan might prove overestimated. Some profects may prove non-viable, or hoped-for 1nvestment funds from abroad may not materialize; others way be unavoldably delayed.

Strategy of the Plan

2.10 Emphasis on the completion of carry-over projects, on 1mport subst1tution in consumer goods and maintenance inputs, and a move into relatively advanced technology and capital intensive projects (such as copper-smelting. steel-making through a gas-reduction process, a second fertilizer plant, and an oll refinery) appear as the major features of the industrial sector plan. 
The peaking of investreats noted in paragraph 2.4 is largely due to completion of carry-over projects and projects such as the kunduz $I$, hieloosd and badghis cotton ginning plants, and the replacezent of Baghlan sugar plant machinery. Around 602 of the investments is intended for import-substitution (e.g., cotton textiles and sugar) and maintenance inputs (e.g., ginned cotton, petroleua, cetent, coal, fertilizers, chemicals, etc.). Roughly $10 \%$ of the investments are intended for balancing and modernization (e.8. a power turbine at the existing fertilizer plant, a hew gas desulphurization plant to replace existing facilities, replacement of existing machinery at the Baghlan sugar plant), and around $9 z$ of the investments are for consumer goods (e.g., bakery, grain storage, etc.). In contrast, around $21 z$ of the investments are for the preparation of the two big projects in the metallurgical sector.

2.11 In general, the emphasis on resource-based industries, and import substitution industries appears reasonable, and the balancing and nodernization investments are probably approprlate too. There may, hovever, be more scope for export-oriented resource-based industries. A major reservation must, however, be expzessed in regard to the inadequacy of economic analysis to demonstrate the value of projects to the economy as a whole (see paragraphs 2.13 to 2.17 ); and there are problems of intersectoral consistency as indicated in paras. 2.18 to 2.20. In general terms, it seems reasonable to assume that projects in such fields as cotton ginning and textiles, sugar, cenent and food produc's would be shom to be economically Justifiable. This may very well not be the case for the 1 ron and steel project and for copper, and perhaps, for the second fertilizer plant. It is appreciaced that much of the cost envisaged for these during the Plan period is sieply for further study. On the basis of what is known about these projects, and general considerations of comparative advantage (ste paragraphs 1.15 to 1.23 ), they wight not prove to be worthwhile investments. Their inclusion in the Plan is, therefore, more a statement of possible budgetary needs than a statement of positive intention. - It would be helpful if a clear Jistinction would be made between a) projects which will require certain expenditures; b) projects which are likely to require certain expenditures, but which are still under study; c) provision for technical and econonic feasibility studies for projects (such as the iron and steel plant and the copper project) still in an early stage of preparation; and d) provisions for studies designed to help identify possible future pro$j$ jets. During the course of plan implementation projects would then progress from one category of certainty to the next.

2.12 Detafled studies may show these large capital-intensive projects to be soundly based and in Afghanistan's long-term econouic interests. But it is important that the appraisal techniques used recogaize the limited availability of investment funds, of foreign exchange and of skflled canpower in Afghanistan. If they do not, resources could be misallocated. Undue exphasis on thea, at this stage, may only dissipate Afghanistan's Iimited investment capacity, and technical and managerial manpower, to the detriment of growth pcssibilities in short-gestation projects with more imediate effects on dowestic output and relaxation of foreign exchange constraints. 


\section{B. General Economic Criteria and the Plan}

2.13 There is an impression of a lack of adequate reference to economic celteria in the process of selection of profects. Technical feasibility seems to have been the dominant consideration. The Plan as 1t stands now is a collectior of projects, for most of which even technical feasibility has been established only in a prellmiuary way. Although major projects in cotton ginning and textiles (e.g, Kunduz I and II, and Balkh) have had theit technical feasibilities assessed only fn a very rudimentary manner, as have the Herat sugar m111 and the cement plants at Kandahar and Herat, this 15 not too serious in the context of the plants theaselves. Provided raw material supply is adequate, there is unlikely to be any technical reason (though there may be economic vnes) why they should not be viable. Hovever, in some cases rav material supply is questionable. The sugar mill at Berat, for example, is dependent on the creation of 1rrigation facilities by constructing a dan on the Harl Pud and a presumed shift of the cropping pattern. Similarly, for the cement plants, inadequate attention seems to have been paid to the avallability of the main energy source, coal, to be transported from the mountains beyond Herat. The latter profect is liable to be a very difficult one and its technical feasibility does not seem to have been assessed. These are signif1cant uncertainties.

2.14 With regard to economic criter1a, such basic considerations as capical labor substitution, and desired economic rates of return seemed to have been hardly observed. The alssion sought and fafled to obtain any clear idea of intra-sectoral priorities. The Impression one gathers is that no prior directive was 1ssued in this regard to guide the investment priorities vithin the Industrial sector. Accordingly, the employment potential of the sector, both direct and indirect, is unknown. It is posstble, of course, that except for the projects in the ertallurgical, natural gas and machinery sectors, exployment generation could be substantial. Hovever, it is important to note that in the absence of clear directives, project designs in the various subsectors could be unnecessarily cap1tal-intensive.

2.15 On the question of incremental capital-output ratios determining the economic viability of the projects, the Plan is equally vague. The stated expectation is that the coefficients would vary between 2.5 and 3.1 . This latter is not substantiated by details avallable on the projects, and there appears to be a general bfas towards quite capital-intensive installations.

2.16 At the individual project level too, the failure to use standard econumic criteria in project appraisal may have led to wrong conclusions. Shadow pricing or equivalent analytical procedures appear not to be used at all, except occasionally as "theoretical exercises", and the concept of discounting is appreclated by only a few. Some do not consider loan service as part of the cost of a profect. Without establishing a sultable project appraisal framework there is an obvious danger of:

(a) emphasis on capital-1ntensive projects and inadequate stress on employment creation; 
(b) emphasis on large, long-term projects, rather than those which bring quick benefits; and

(c) too little emphasis on income creation or distribution.

2.17 Leaving aside broad economic considerations, there is insufficient analysis of individual projects to establish whether they would be even commercially viable. Problems of raw material supplies have already been referred to. Market or manpower studies are often carried out, if at all, only after a decision has been taken to go ahead on the project. In contrast, when private sector projects cose up for final approval under the FDPIL, they do have to demonstrate their viability - and Indeed their impact on the economy as a whole.

Some possible sectoral inconsistencies

2.18 Cotton ginning and cotton text1les. As Table 7 indicates, 55, 000 tons p.a. additional ginning capacity is envisaged (a 922 expansion), while cotton textile output is expected to rise by a 100\%. Increased absorption of ginned cotton by the textile mills would take around 57 thousand tons of the total ginning capacity, so that the exportable surplus in the terminal year of the Plan would be around 58 thousand tons, compared to around 38 thousand tons in 1975/76. The projected supply of rav cotton 1s, hovever, 180 thousand tons or an increase of 106 percent, so that there could be a possible shortage of ginning capacity (compared to a slight surplus capacity today). In view of the varlability of crops, 1 t is probably best to plan for a surplus of ginning capacity in an average crop year. In cotton textiles, the aim is toward complete self-sufficiency and elimination of current imports conservatively estimated at around $40 \mathrm{mill} 10 \mathrm{n}$ meters. Afghanistan today lacks an adequate import control system, and it is unlikely that such a system could be instituted in the near future. Consequently a significant volume of imports for reasons of "product differentiation" as well as swuggled imports and 1mports as a vehicle of capital flight from neighboring countries has to be reckoned with. In view of the above, sove reconsideration of the investment prioritles in this sub-sector would be worthwile, taking into account export possibilitier

$2.19 \mathrm{Su}_{\mathrm{i}} \mathrm{al}_{\mathrm{l}}$. The question of inter-sectoral inconsistency is particularly acute in relation to sugar. The estimated increase in production of 59 thousand tons has been envisaged as follows: (1) replacement of existing machinery at Baghlan (annual capac1ty 11 thousand tons) as vell as expansion in capacity to 27 thousand tons per annum; (11) establishment of a sugar factory at Berat with annual capacity of 24 thousand tons; and (i1i) replacement of the present machinery at Jalalabad sugar factory (capacity 1 thousand tons annually) plus additional capacity of 30,000 tons. In each case, the crucial variable is the required increase in the raw material production, sugar beet in Baghlan and Herat and sugar cane in Jalalabad and all that $1 \mathrm{t}$ implies in terms of shift of acreage, irrigation, supply of fertilizer and extension services, and agricultural relative prices. The Baghlan and Herat sugar 
plants dotd require around 180 and 160 thousand tons of sugar beet respectively. Fis would require a $160 z$ increase in output in the Baghlan area. No sugar beet is currently grown in the Herat area except for a small experimental plot and the viability of the proposed investment is dependent on Irrigation facilities following the construction of the Salma Dam on Har1 Rud; a f1rm schedule for this is lacking. Final'y, for the Jalalabad sugar factory, the requirement is for around 300 thouswid tons of cane, while current production is only around 50 thousand tons. Such fncreases in agricultural output are possible, but much will need to be done to achieve them. It can be doubted whether plans are suff $t$ clently advanced to watch the timing of the planned factory completions at Herat and Jalalabad.

2.20 Similar examples of possible sectoral inconsistencies may exist in other sectors also. It could be questioned wether, for instance, it is economically more worthwhile to establish three relatively large public sector bakerles, requiring significant resources of capital and management skills, instead of continuing to rely on traditional private small-scale labor-intensive units. It is not clear whether in determining the need to establish a second fertilizer plant, sufficient regard has been paid to agronomic research considering the optimum mix of fertilizer types for different soll conditions in Afghanistan. The abiding impression is one of the very hastily dravo-up list of projects, and not really a plan that would meet a reasonable set of objective criteria. Very substantial parts of the plan appear not to have progressed beyond project concept and it vill be some time before an assured view of the various sub-sector possibilities and priorities becomes possible. A certain lack of consistency is to be expected in any development program. Nevertheless, the limited investment capacity of the country makes a considerable improvement of the planning process most desirable. To this end, a revamping of the facility for project preparation and evaluation is necessary.

\section{Organization of Planning for Industrial Development}

2.21 Apart frow the role which the Ministry of Planning and the Ministry of Finance play in relation to industry as to every other branch of the economy, responsibility for industry is divided betveen the Ministry of Mines. and Industry (most public sector enterprises, and Industrial parks), the Ministry of Finance (financial control of Tasadys), the Ministry of Planning (the Private Investment Department controls FDPIL - approved private enterprises), the Ministry of Commerce (handicrafts, swall Industries, and industrial exports), and the Ministry of Public Works (certain construction materials, notably prefabricated housing units). Three other Ministries are responsitle for operations wich are partly industrial in character. There is also a need for considerable liaison: with the Ministry of Agriculture on linking output of agricultural raw materlals to industrial needs, with the Ministry of Education on vocational, techn1cal, and management training; with the Central Statistics office; and, with the Power and Water Authority. 
2.22 Though this division of responsibilities for industry is not vithout a certain $\log 1 \mathrm{c}$, it is obvious that it does not facilitate the planning of industry as a whole. Both civil servants and forelgn experts work primarily in a departmental context and rarely consider industry as a whole; indeed departmental jealousies, and undue secrecy are occasionally obstacles to effective planning and implementation. Knowledge and understanding of the private sector is very $11 \mathrm{~m} f \mathrm{ted}$ outside the Ministry of Commerce and the Private Investment Department, and few seem to appreciate the scope for developing smali industry and handicrafts inte a relatively modern industrial sector integrated with and complementing larger-scale industry.

2.23 The deficlencies of industrial planning procedures are appreciated vithin the Mintstry of Planning, the Ministry of Mines and Industry, and elsewhere. But those concerned are already under much work pressure, and feel moreover, that they lack the techrici-skills required.

2.24 It is very difficult, and certainly costly in terms of manpower, to carry out adequate economic feasibility or prefeasibility studies without greatly improved statistics. The feu statistics which exist on the industrial sector In Afghanistan, are regarded by many as being of $11 t$ tle value, and liaison between the Central Statistics office and the Ministries concerned appears poor; indeed access to quite normal statistical detail is difficult. A contributory problem is that fev statistics are available in English, wile many of the potential users of the data are at present foreign experts.

2.25 Recommendations for improved industrial planning are made in Chapter III (para. 3.34). 
III. GENERAL PROBLEMS AND POLICIES FOR MORE R.PIJ INDUSTRIAL GROWTH

\section{Principal Problems and Constraints}

3.1 In this chapter, some general problems of industrial development are considered in relation to the types of industry which appear to have grovth potential (see paragraphs 1.24 and 1.28 ).

3.2 There are five main problem areas:

(a) The lack of management and technical skills, and the related problem of insufficient delegation of responsibilfty in the public sector;

(b) The complexities of the import tariff, export duty and taxation system and their use primarily as the means of raising revenue, and hardly at all as policy instruments;

(c) The lack of any clearly defined role for the private sector, and the somewhat negative ambience for private industrial investment;

(d) The confused structure of public sector enterprises, in relation to both state control and to one another, and the lack of clear objectives to wich their managers are held responsible;

(e) The inadequacies of industrial planaing procedures, stemming perhaps in part from divided control.

The first two of these are discussed in this Chapter. Point (c) is covered in Chapter V, point (d) in Chapter IV, and point (e) in Chapter II.

\section{Problems of Management and Technical Skills}

3.3 A recent quantitative assessment of the manpower situation in 16 public sector enterprises by the UNIDO Industrial Services Project in the Ministry of Mines and Industry suggests that existing needs and the expansions envisaged under the Seven-Year Plan imply the following additional manpower requirements:

(a) $76 z$ more management, administrative and cleriral staff;

(b) 2237 more engineers and technolcgists ( $450 z$ sore than the existing number of Afghan engineers and terhnologists);

(c) $184 z$ more technirians and foremen (202z more than the existing number of Afghans in this group):

(d) $34 z$ more skilled and unskilled workers.

Further detalls appear in Annex B. 
3.5 in iaplications of the anticipated additional ma:power requirements are $\ldots$ zreater than indicated absve if the manpower Geficiencies in existing fublic sector industries, notably with respect to training and experience, are considered. No douht many individuals are carrying out jobs for which they lack training, and in some cases adequate experfence too. But reliance on such improvisations also Involves considerable risks. Afghanistan cannot afford major development projects to fall for such reascns. Serious qualitative jeficlencies prevall both at the ergineer/ rechnologist leve 1 and in tanagement and administrative functions. There 18 a marked lack of practical experfence among engineers, and those who have acquired such experience abroad have normally stayed there. Ir management and administration, the deficlencies are notably in (a) accounting, finaacial control and budgeting; (b) marketing and market research, and (c) forward planning and planning for new product 1 ines.

3.5 The problems of private industry in respect of management and technical skills are probably less acute than those in the public sector. The main reasons are:
(a) private sector enterprises are generally much smaller and therefore make fewer management demands;
(b) in general, private sector firms employ falrly simple technologies;
(c) because of their greater freedot of action, and also because they are aore connitted to achieving financial success, managements of private sector enterprises tend to act in response to percelved needs.

However, while the few large private sector enterprises generally have superior accounting, marketing, and planning systems to any found in the public sector in Afghanfstan (apart from Afghan Text1le Co. which only recenty became public sector), they have even greater difficulty in getting technical staff. This seems to be largely because, in spite of higher private sector pay, many Afghans prefer the prestige and securlty of a government job. Moroover, public sector firms have readier, and cheaper, access to foreign technicians, than do private sector undertakings. Consequently, In tho past large private firms themselves financed the education abroad of appropriate Afghans, keeping them under contract on return.

3.6 Small private sector enterprises rarely have recognizable accounts or other management tools. Nor do they comonly recognize any need for these. Because of their size, their concentration on few product 11nes, and the generally siaple technolngies applied that involve relatively small amounts of fixed capital, these deficiencies have been less serfous than aight be expected. They have, however, been an important factor in preventing these firms frow growing. 
3.7 It should be pointed out that in relatively simple enterprises suct, as exist in afghanistan, skill developtert wee:s to be fairly broad, and the training of ergineers in management, echniques is normally as inpurcant as tectuical knovledge.

3.8 The lack of Afghans with the skills of modern management, rotablv account 3nc: and markcting, or with praciscal esperlence of working in modern :usiness esterprises, whether in Afghar:stan or abroad is probably tie Largest single umediate obstarle to builcing up a viable inciustrial sector, public or privare, in Afghanistan. It is probably even more crucial than the shortage of eaglneers and technicitas, because:

(a) while there ar: 1irited numbers of Afgtass with adeccuate technical training, tiare are hardly any in the management sciences;

(b) It in less oroblematic tc use fortign taci ictanc or engineers +han foreigu marage:3;

(c) the skills take longe: to devexop, because practiral experzence has to be grafted onto the basic academic grcindwork to an ever greater extent rnan in echnical ílelds.

3.9 Related to the lack of minapemont ard techn'.cal sulls is the probles of sufficienc delegation of responsibility in tre public sector. Executives cannot bi expected to ensure the overal viabillty, and secis to develop further the ope-acions $n t h$ which they are entrusted, if relacively minor aspects of hf:ir day-to-day operztions have to de vetted by superv-sors. It is evident tiat 'residents of E-terprises commonly spend so much time approving :elativel; minor matters of detail - purchises, staff proł lem:, etc. tiat they are urable to consider he tajur long-term proolems facing these enterprises. It also appears that the ope $z$ ationd effectiveness of enterp-1ses is greater the more the delegation of respinsibiilty. It is arpreciated that a major reason for the lack of delegaticn of responsibility is the poor calibre If san, is of Jle manage-rent. Buc in addition, the sys sem cf control oi many enterprises ruquires Presidents to take far too many day-to-day decisions, and indeed responsibility cfted shifts frcm che President to the Ministry Eence even when a Frisident can trust his subordinates to take correct and cesponsfble decisions, their development as potential senfur executive- is af-ectid by the fact that they causo: be made fully responsible. It will be inte stiug to see to what extent the new sys :ei in Jangalak Industries, i-troduced or tLo advice, will succeed in coping -ith the managerial problems of that encerprise.

3.10 The problem of tרsufficieat managereat and technicai skills s a formidable one in the coni $x t c$ the Seven-Yeat Plan. The Jovernment's new educational policy could be an ispurtant step in the right direction, particularly in the costext of developing tecnnical exportise. The aif is tu increase the vocational and technical proportion $c$, those going into secondary education from $6 z$. 197ji76 to half. The pulicy implies that in educational 
planning, programs should be fob-oriented and should be relatcd to the country's general socio-economic develcsatnc. Measures to give effect to this policy, are still in the early stages of developent, though. Moresver, 1t must be pointed out that:

(a) In spite of increased emphasis, educational spending is still accorded a relatively low priority in government spending (only $3 z$ of $1975 / 76$ investrents, for instance, in spite of the lack of physical facilities in many areas);

(b) The effects of the new policy can only be felt in small part, as far as higher technical and zanagezent skilis are concerned, during the Seven-Year Plan perfod;

(c) While the policy recognizes the need for training in accounting at secondary level, manzzesent training and the developmeat of accountancy skills to tigher levels get insufficient recognition.

Annex $C$ gives some detalls on training facilities for industrial development in Afghanistan.

The Indirect Tax System

3.11 One of the most 1aportant single poilcy instruments 1n seek1ng to establish an industrial base is normally the establishment of efficient protective tariffs. In Afghanistan, however, tariff policy has lonz been oriented to revenue ralsing. In view of the isportance of import duties as a source of govirnment revenue (see para. 1.5) it is natural, though perhaps not unavoldable, that it should be seen primarily in this light.

3.12 The current customs tarfé structure and other levies are often identified as one of the mafor impediments constraining private investment activity in Afghanistan. Interviews with local industrialists revealed a common dissatisfaction with the custons tariff structure and other fndirect taxes.

3. I3 The Customs Tariff. The present tariff structure was promulgated in June 1974 and has since then been modified in the annual budgets. The present customs tariff supplanted a twenty-year old structure. The comodity classification in the present tariff schedule is significantly more detailed, with increased commodity coverage. The classification is also linked with the SITC and BIS systens through cross-coding of the tariff numbers. The new tariff schedule contains a number of increases in tariff rates for revenue purposes, particularly on luxury iteas (e.g. automobiles, chocolate, etc.). It also attested to extend and rationalize tariff protection for donestic manufacturing industries, particularly those at an early stage of developgent, through a system of graduated tarifts depending on the degree of processing. Simultaneously with the introduction of the new tarlff, the list of prohibited 
imports was restructured; the prohibfted list was further modified by the inclusion of another 74 itens in $1975 / 76$ to encourage import substitution. Actual tariff rates vary considerably - between $20^{\circ}$ and $35^{*}$ on stated specific values, being falrly typical for finished preducts.

3.14 Service Charges, Red Crescent Charges and Fixed Tax. Closely related to the Import tariff are these three charges. Service charge is assessed at $2 z$ of the import duty payable, while ked Crescent charges are assessed at 17 of the total of Import duty plus service charge. Fixed tax is assessed at 67 of the total of ex Kabul c.i.f. value plus all the above dury and charges payable. The application of the Fixed Tax is, however, different for goods classified as a Monopoly and a Monopoly Tax is payable on such 1mports. The procedure for the calculation of the tax llability in this case is quite complicated and makes perceptible denands on the Iimited manpower trained for that purpose. The procedure is still core cotplex for goods classifled as luxury.

3.15 Monopoly Tax. Monopoly tax is charged on the total of the ex-Kabul c.1.f. value, import duty. Service Charge and Red Crescent Charge plus a Compission Tharge assessed at $2 \%$ of the total. The Monopoly Iax is then assessed at $15 \%$ of this total. Finally. at the end of this trall, comes the Fixed Tax at $6 z$ of the c.1.f. value of the gord in question plus all the above taxes and charges.

3.16 Luxury Tax. For this there are two additional twists in the form of a flat rate special charge called an Authorization Charge and a variable rate (according to the country of orfigin of the goods in question), called Privilege Charge. The Authorization Charge, is assessed at $5 z$ of the total of fuport duty, Service Charge, F.ed Crescent Charge, Monopoly tax (1f applicable) and the ex-Kabul c.1.f. value of the good in question. The Fixed Tax is then assessed at $6 \%$ of the total. The calculation of the Privilege Charge and the consequent Luxury Tax exclude, however, the Fixed Tax. The base price for Privilege Charge is calculated as the sum of the ex-Kabul c.i.f. value fo the goods and all charges payable as described above but other than the Fixed Tax, and the Privilege Charge is then calculated on the basis of the following rate structure:

Country of Origin

Asia

Europe

America

\section{Privilege Charge (2)}

8.0

12.0

13.0

The rate structure nakes no allowance either for the type of good or its country of origin vithin a bloc. Sior does it mention Africa and Australia; rates for these presumably depend on the uncertain interpretation of the rules by the customs authorities. The Luxury $\operatorname{Iax}$ is assessed at $5 \%$ of the base price as described above plus the Privilege Charge. 
3.17 Consuper Goods Tex. Th1s tax was promulgated in Apri1 1974 and is a singte stage tax on consumer goods produced and sold domestically. The tax is collected from manufacturers. The tax rates are specific but are generally fixed to amount to around $6 z$ of the ex-factory price. For a few 1 tems the rate $1 \mathrm{~s}$ assessed at $10 \%$. Very few products are exempted altogether; only books, newspapers and other Itens printed in Afghanistan are so treated.

3.18 Turnover Tax. Domestic manufacturing establishments are also subjected to a flat-rate (2Z) turnover tax on sales made. There are very few exemptions, the wost notable being pharmaceuticals.

3.19 Iotal Indirect Tax Incidence. One of the ways in which relative tax incidence in the present context can be viewed is by deriving an aggregate measure of the various taxes and charges described in the preceding paragraphs and comparing this with the tax incidence on competing imports (including all additional charges). The approach here is reminiscent of the 'effective protection' type in the sense that all indirect taxes and charges on inputs and finished products and not just the customs tariff on the raw material are taken into consideration. The basic data vere obtained on the basis of a representative sample of the major private sector industries in the Kabul area enjoying FDPIL concessions in eight subsectors. Wherever specific tariffs are prevalent, ad valorep equivalences at current prices have been obtained. The approach is best explained by an illustrative example. On imports of Afs. I.S million, the product concerned which enjoys FDPIL concessions is subject to a total of Afs. 295,000 In duties - a tax incidence of 11.82 on an output of Afs. 2.5 million.

Iaxes and charges payable

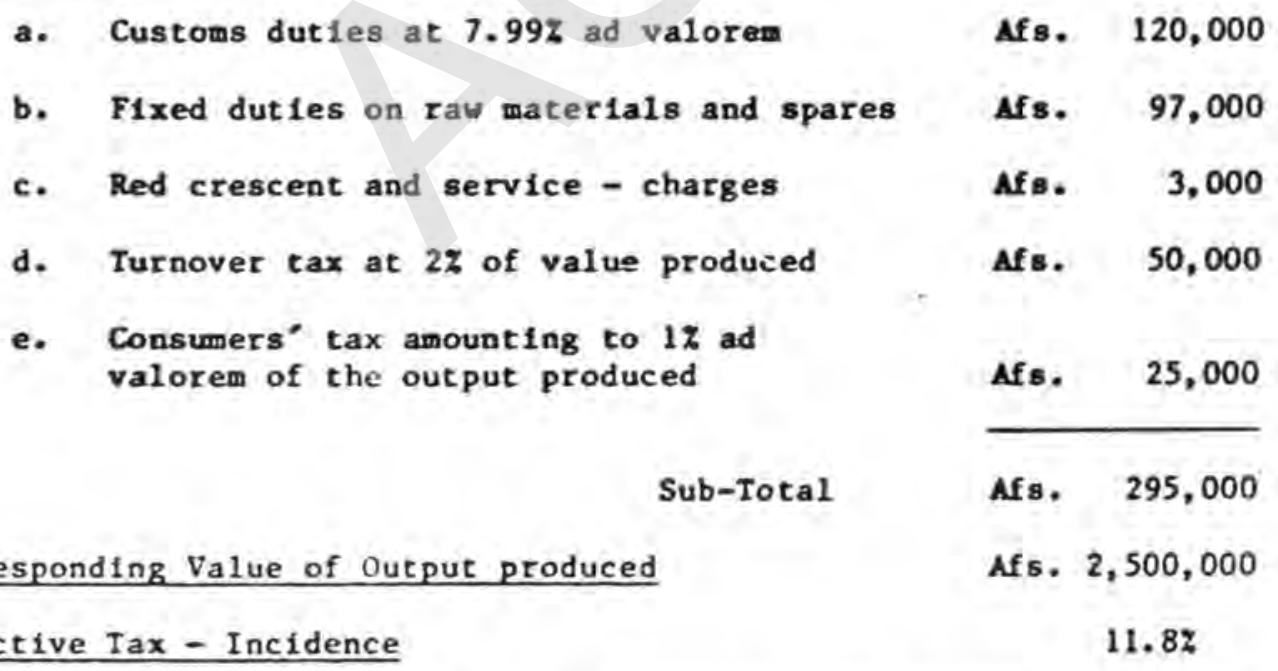

This compares with a $28 \%$ nominal tax incidence on competing imports. If the firm vere to pay 1mport duties at the nomal non-FDPIL 1mport duty applicable ( $20 Z$ ad valorem) on similar substances (1.e. customs tarfff - June 1974, Covernment of Afghanistan, AG Code No. 3404), the above charges would have 
been enhanced by about Afs. 193,000. Effective tax-facidence would then have been about 19.5\%. .

3.20 Table 8 shows the results of the calculation for the elght selected sub-sectors.

Table 8: Comparat1ve Tax Inc1dence in Private Sector Industry (1n 3 )

$\underline{\text { Sub-sectors }}$

1. Textiles

a. Rayon

b. Knitting

2. Leather and footwear

3. Pharmaceuticals

4. Detergents

5. Lubricants

6. Automobile batteries

7. Plasticuare

8. Paints and dyestuff
Total 1ndirect tax

incidence on domestic

produce enjoying FDPIL concessions
'Vominal' tax Incidence on compet1ng import

It is demonstrated that, except in paints and dyes, these industries enjoy significant, indeed in some cases very substantial, protection. Any firms which did not have FDPIL status in these sectors would have considerably less protection.

3.21 Compet1tion from Unrecorded and Undervalued Imports. Nonetheless, the arguments of domestic manufacturers that they face discriminatory taxation vis-a-vis imports have some validity, although by its very nature the extent of any such discrimination cannot be proven. Many imported consumer goods enter through 11 legal channels without payment of tarfffs and other charges. For those imports coming through legal channels, there is also widespread under-1nvolcing with or without the connivance of customs officials, as a vehicle of tax evasion. Many private industrialfsts consider this more important than the alleged forwal tarfff discrimination. Undoubtedly donestic manufacturers also sometimes underdeclare the values of imported raw materials, but their size and 1dentifiability and the requirements of the FDPIL to give detalls on their anticipated operations to qualify for taxprivileges restrains the scope for such tax evasion. Finally, it seems that certain competing imports are under-involced vehicles of capital flight from neighboring countries into Afghanistan, where funds can then readily be converted into major international currencies; such imports sometimes sell at a discount within Afghanistan and put local industry at a further disadvantage.

3. 22 Scope for Simplification. The indirect tax systen on imports described above is clearly unnecessarily conplex, and could easily be simplified without affecting reveriues. Thus at current rates, the various 1 mport taxes and charges on lubricants cone to about 317 ad valorem. Considerable procedural simplicity could be obtained if a single tax of such magnitude 
vere to be laposed. Tax administration 1s a skill-intensive operation and Afghanistan could use these skills better than in the present indirect tax structure with its procedural complexity. Simflar simplification need also be sought by consolidating the turnover tax and censumer tax into a single excise. This vould constitute a considerable improvement from the viewpoint of tax administration and would be easier for industry to handle and understand, too. Corresponding changes would be needed to maintain effective FDPIL protection at current levels.

\section{Export Tariffs}

3. 23 These, generally around $15 \%$ to $30 \%$ on a wide range of export products, are a feature of Afghanistan's eccnony. Certain industries are exempt, as are most handicrafts. In principle such duties should not apply to the products of FDPIL-approved ent-rprises. But in practice it seems that they are sometimes levied. And there appear to be examples where the industrial products, if exported, would bear a higher duty than does the exported raw material.

\section{Quantitative Restrictions on Foreign Trade}

3.24 In addition to tariff restrictions, Afghanistan also has some quantitative restrictions on certain 1mports. Indeed, in 1975/76, 74 tems were put on the 'banned' 11st, and currently some 100 items (e.g., alcoholic and non-alcoholic beverages, firearms, etc.) are on the 11st. The prohibitions are generally on religious or other public policy grounds, but some are intended to stimulate import substitution. There are, however, a few potentially quite significant imports on the list. They include Pakistani cottons, cotton and ayon blankets, furniture, and carpets, rugs and embroldered cloth. There are also certain export bans -- of which the most important are on textiles -- though 1 imited volumes are permitted. The reason for export bans appears to be to ensure that all, or nearly all, of local textile output goes to the local market to stem the inflow of foreign textiles. One of the reasons for such trade are the price controls on local textiles, while there are no such controls on imported textiles; it thus pays producers to export as much as possible. However, the textile exports which have been cut back are predominantly medium quality cotton yarns and grey cloth, while the imports thave been low quality finished products. Af ghanistan was probably a net beneficiary from such trade, and managements of both public and private sector firms believe they could export more, if permitted. The need to keep domestic prices down is cited as the justification for the export ban. It should be asked, however, firstly, whether it is really impossible to control prices of 1mported text1les as well as those of local goods; and secondly whether the lower prices for local textiles are really being passed on by traders to consuners.

3.25 The seope for an 1mport tariff, export duty and foreign trade control policy geared more towards building up local industry is 11 trited by government revenue needs. In total, taxes on forelgn trade accounted for $45 \%$ of government revenue in the 1354 (1975/76) budget (provisional actuals). 
It would be difficult to introduce a development-orientated foreign trade taxation and control system which is sutficientiy selective and flextble while the government's freedon of action is constrained by the need to maintain revenues from taxes on foreign trade. It would obviously be easier if revenue fron direct taxes and internal indirect taxes could be stepped up. But this would be very difficult, perhaps impossible, without zore adequate accounting standards being enforced on all types of businesses. Besides, personal and corporate incones may just be too low at the country's current stage of development to seriously consider any geasurable shift from indirect to direct taxation. Fote, hovever, that wile the company incoce tax rate, at 20z, remains below the effective rate of duty on most imports, the incentive to traders to understate import values realins (for nost imports the tax saved through this understatement more than offsets the additional income tax to which the trader should in principle be subfect); in wany countries company income tax rates are three times or wore the typical import duty rates.

\section{General Recommendations}

Note: Recommendations speciflc to the public sector appear in Chapter IV, while those specific to the private sector appear in Chapter V.

3.26 For a variety of reasons, it seems quite likely that the large investments envisaged in public sector industry in the Plan will not be realized in full. For some projects it vay be inpossible to obtain finance. Further study may show others to be either technically or economically unfeasible. The implementation of yet others may be unavoidably delayed. With or without this shortfall, there should be increased eaphasis on the development of private sector industry, which is capable of playing a more important role than the Plan envisages. Specific measures to give expression to this general recommendation are discussed further below and in Chapter V.

3.27 Within the planned development of public sector industry, the present emphasis on resource-based projects appears correct. There are, however, certain individual elements which should be re-examined, particularly those which will involve heavy capital investment and advanced technologies. In particular, the potential economic benefits from the 1ron and steel project and the copper project should be determined as a mater of urgency.

3. 28 As handicrafts and small-scale industry are around 25 to 30 times the size of FDPIL-approved private sector industry in terns of employment, and perhaps up to 5 times as important in terms of contribution to GDP, a 57 per annum growth in handicrafts and scall-scale industry would at present contribute more to national incomes, than would a much larger annual increase in the output of FDPIL industry (or indeed of public sector industry). So within the private sector, particular emphasis should be placed on the development of handicrafts and small industries into more efficient units, with due regard to maintaining employment levels. So far only the first steps have been taken towards what is bound to be a long process. (See paragraphs 5.33 to 5.34 for specific recormendations). 
3.29 To develop larger-scale private sector Industry (In essence the FDPIL sector), the maIn step which needs to be taken is the creation of confidence and of a more postive amblence (see paragraph 5.31 fni specific recommendations). Substantial private sector projects are imposslble without forelgn funds, and there is scope for more foreign investwent which cine Private Investment Department should seek to encourage.

3.30 There seems to rather more scope than the Plan envisages

for:

(a) Medlum-scale import substitution Industries and those Introdicting sew products to Afghan consumers (e.g. processed foods):

(b) Medium-scale industries based on increased processing for export of products of local agricultural origin (e.g. leather and wolen gojds).

Such Industrles appear particularly suitable for the FDPIL private sector, with smaller enterprises being mostly wolly Afghan in ownership, and the larger ones Involving foreign particlpation.

3.31 It needs to be recognized that, unless there are political or soclal considerations of a quite exceptional nature, no major industrial project should go ahead unless it can be demonstrated that it will be to Afghanistan's economic advantage. While, so long as protection is not excessive, this would normally be the case for any private sector project from which the entrepreneur can expect to make a comercial proflt, careful appraisal is needed of public sector projects, particularly in the context of intersectoral linkages and the pricing of Inputs and outputs where these are from or to the public sector, or where they are determined in intergovernmental deals. It is also important to ensure that when the benefits from a profect are shared between Afghanistan and a foreign entrepreneur or government, Afghanlstan gets a falr share of those beneflts. Paragraph 3.34 makes specific recommendations for the establishment of a Planning Unlt for industry, but it also needs to be recognized by the government that the recommendations of such a unt would not be mere theoretical exercise, and should normally form the basis for goverment decisions.

3.32 The government's new educatlonal policy puts considerably more eaphasis on the development of vocational and technical training. This is to be welcoced, and Its success is of key importance to the development of a really significant industrial sector in Afghanlstan. But within this policy, there is need for a greater emphasis on developinp menagement and accounting skills, and for prcgrams specifically orlentated towards the strengthening of the handicrafts sector. Attention also needs to be devoted to ensuring that appropriate students are attracted to be trained in these sk11ls. And vocational and technical training in general should be linked, as is pianned, to the development of industry as a whole. 


\section{Planning and Coordination}

3. 33 The divided control of industry between the Ministry of Mines and Industry (most public sector enterprises, pre-FDPIL private sector, and Industrial parks), the Ministry of Commerce (handicrafts and small industries), the Ministry of Planning (FDPIL approved private 1ndustry, and overall economic coordination), the Ministry of Finance (financial control of Tasadys), and for certain Individual industries, four other Ministries, should be rationalized. In particular, public sector, FDPIL private sector and small lodustry and handicrafts should be planned for as a coordinated wole, though the institutional support and control functions obviously need to be different. It is important to ensure that any new system grouping all types of industry under a single Ministry recognizes that handicrafts and small industry constitute the bulk of the industrial sector whether in terms of output, employment or exports, and vill continue to do so for some years to cone. It should also recognize the potent1al for new FDPIL-approved industries, particularly in respect of import substitution. The Ministry of Mines and Industry is at present not equipped to take these considerations into account adequately.

3.34 Planning and coordination for the indistrial sector should be strengthened. This may best be achieved by establishing an Industrial Planning Unit in the Miaistry of Mines and Industry wich has statutory control over the most important public sector enterprises. The unit could build on the work already being done by the UNIDO Industrial Services Project. The functions of the proposed Planning Unit for industry should include:

(a) coordination of development among public sector industrial enterprises, the private sector and to the extent possible, small Industry and handicrafts, with agricultural and other raw materlals output, and with vocational and technical training;

(b) zesponsib1lity for the econonic aspects of pre-feasibility studies on public sector industrial projects, and/or review of feasibility studies on public sectors industrial profects;

(c) Identification, in consultation with IDBA, of potential new industrial projects, suitable efther for the public sector or for private investment; this $11 \mathrm{st}$ should be based primarily on pre-feasibslity studies;

(d) advice to the Private Investment Promotion Department in the Ministry of Planning on the acceptability of applications for FDPIL approval which involve an investment in excess of, say, Afs. 50 millfon; and

(e) development and training of Afghan staff in economic planning for industry. 
This Planafng Unit should be headed by a person of "President" status, In addition to Afghan professional staff, employment of international experts ayy be needed for some tipe.

3.35 A considerable improvenent of statistical support is of key isportance to adequate planning for industrial development. To chis end, the work of the Central Statistical office (CSO) needs to be reorganized and isproved. In relation to industry, priority should be given to production of statistics on all types of industrial output, naterial inputs and consuption patterns. Iiaison between the CSO and other government departments apparently peeds laproving. It should also be recognized that at present zany of the potential users of such statistics withil Afghanistan cannot read Dari, and seem unaware of what figures are available. Suitable translation facilities should be provided.

\section{Manpower Development}

3. 36 While peasures are in hand to develop skills at tise engineer, technician and skilled worker levels, urgent steps are necessary to 1mprove deficiencies in management, control, and administration. A Management Development Centre should be established. Though intended primarily for the public sector, it should be open also to the private sector; indeed the private sector should be encouraged to use it. Accounting courses should be of particular value to them. Though funded by government and possibly including an international assistance element, it should operate outside any Ministry, It would need to cooperate closely with the Ministry of Education and the proposed Industrial Planning Unit. The detafled work program should be deterained folloving conpletion of a feasibility study, and the planning of required facilities and staff should take into account existing institutions, particularly the ILO Training Project.

3. 37 A coepetent organization or $\mathrm{firm}$ of accountants is required to:

(a) establish proper accounting procedures fot the public sector enterprises and instruct staff in these procedures;

(b) audit the accounts of publ1c sector enterprises (see paragraph 4. 32);

(c) train suitable Afghan personnel to fully professional levels to take over functions a) and b) above.

The organization or firm could probably operate within the framework of the Management Development Centre, or in association with IDBA, 4 or 5 qualified accoutants vould initially be needed for the functions listed above. Though there is a need for a recognized firm of accountants to carry out audits of cocmercial fircs on commercial terms as well, the demand for these services is unlikely tn be iarge until audit requirements for tax purposes are stiffened.

3. 38 The above-mentioned recommendations cannot fully meet the trained managenent gap within existing and planned public sector enterprises. An additional possibility might be to establish management teams with external 
assistance for individual (or groups of) state enterpeises similar to the ILo tean now operating within Jangalak. Their functions would corbine day-to-day eanagement with on-the-job traiting for the Afghan staff, who vould eventually take full control. Such teams : ould also be related institutionally to the Management Development Centre. The precise needs would depend on the character of the industry involved and the skills alread; existing in 1t. For enterprises where existing management teams are inadequate, typical nesus might include:

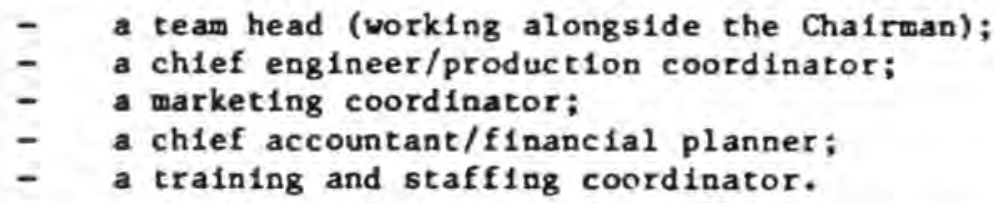

It is obvious that a project of this kind would be expensive, partiy because of the number of corporations involved. With the right people working in the right framevork, it could, however, be very cost-effective, particularly in view of the government's commitment to an expansion of industry for which the required management skills are serfously lacking.

\section{The Tax System and Related Problems}

3.39 It appears from paragraphs 3.19 and 3.20 that in a formal sense, the 1mport tariff and indirect tax system do not in general discriminate against domestic manufacturers; indeed the formal protective margins are quite high. There is, therefore, no case for another revision of the 1mport cariff on these grounds alone. Certain anomalies, were there is negative protection, as in paints and dyestuffs, should be eliminated by reduction in duties on the relevant raw materials. There is, nonetheless, a very real absence of protection to local manufacturers stemning from smuggled and under-invoiced imports, which appear to be of considerable er.onomic significance in Afghanistan. However, increase of formal protection to manufacturers could well 1ncrease the incidence of malpractices. Rather, steps should be taken to try and eliminate them. A better syster of customs inspection and minimum values for tariff assessnent may have to be introduced to ake it sore difficult for Importers to understate import values. Heavy fines should be imposed on those found to be doing so, and customs officials conniving in such practices should be punished.

3.40 The system of indirect taxes should be rationalized. There should be a single import tariff combining the present Customs Tariff, Service Charges, Red Crescent Charges, Fixed Tax, Monopoly Tax, Authorization Charge, Privilege Charge, and Luxury Tax. Adjustment wuld be needed to ensure that FDPIL protection is maintained at present levels. The Consumer Goods Tax and the Turnover Tax might also be combined. Apart from combining these taxes, the protective structure should be recast to ensure that the effective rate of protection is broadly similar on all types of industrial products, so that warket forces play a more effective role in resource allocation.

3.41 Export taxes on industria! products should be eliminated, except where it is clear that Afghanistan enjoys a sufficient corparative advantage for taxes to have a less than corresponding effect on the value of exports. Where products can be manufactured locally from semi-finished products now 
exported, with greaser net economic benefit to Afghanistan, export taxes on the seral-finished product atght be increased to encourage local manufacture. Leather products are a possible example.

3.42 The existing export bans or controis on certain industrial products, notably textilcs, shouid be reconsidered to determine whecher they really act in Afghanistan's econowic interests.

3.43 The system of taxation within Afghan1stan needs strengthening -

(a) To Increase cevenue yields; this should eventually permit import $t_{\text {i }}$ iffis to be set at lower levels and would reduce the infiartunary effects of present tariffs.

(b) To zoic it tairer in operation as between those few firms witicn liep adequate books, those on thicn some information iv avilable, and those on wich there is none. (Foreign in restur: and all sizeable private industrialists are piaklizer now and this discourages traders from putting furds in to industry.)

3.44 To arilivo these ends the company tax rate should be increased; in time it should bes set above the effective rate of the combined duties levied on typiral imfort : (this should help to elfminate the incentive to understatement of sport values); and the consumer goods tax should be cut at the same time. Mosi important of a11, the systen of Income tax assessment needs to be clarifiea and applied in practice wth equal vigor on all types of business according to ciearly spectfied rules. It needs to be less arbitrary in nature. The formulation of a "statute of Ifmitations" on income tax assessments would remove one major deterrent to investment of existing and prospective enterprises. A key step to making this possible is the improvement of accounting standards and knowledge both within Afghan industry generally, and with the incone tax authorities. Addftional specific measures wich might be considered are:

(1) acceptance of accounts audited by a government-approved auditor as $a$ basis for income tax assessmeat;

(11; in the context of i) above, a clear statement is needed of what expenses are tax-deductible and what allowances are permitted;

(111) firms wich do not have audited or othervise reasonably adequate accounts pay tax on the difference between their turnover (assessed If necessary by the tax authorities) and the total of expenses and allowances for wich they can produce adequate documentary evidence;

The difference between i) and 1i1) above in the amount of cax payable should be a powerful incentive to produce adequate accounts.

3.45 To advise op the rationalization of tariffs, indirect taxes and business taxes, there would be need for the assignment of two or three tariff and revenue specialists to Afghanistan. The subject would have to be considered in the context of an overall study of the country's publin finances. 
IV. PUBLIC SECTOR INDUSTRY

\section{Background and Character18t1cB}

4.1 Public sector 1ndustry in Afghanistan has two origins: enterprises set up as private firms which have subsequentiy come under government control; and enterprises established as state ventures. The former category, mostly long established operations, includes some of the largest public sector, enterprises in Afghan1stan: Afghan Text1le Co. became a state enterprise only through the recent nationalization of the banks, that were njority shareholders; In Spinzar, the government acquired a majority shareholding; the government was forced to take over the four units which now constitute Balkh Ginning, Pressing and 011 Extraction because of the1r increasing debt to the government; and Woolen Industries of Puli Chakr1 is a former German-owned operat1on which closed down a few years ago, and has now been recpened by the government. The enterprises established as state ventures are generally more recent in orfigin, dating mostly frow the $1960^{\prime} \mathrm{s}$. The fallure of private enterprise to develop significant new Industries since the Second World War was one reason for the government inltiative, whlle some of the new operations were based on Soviet assistance. The Seven-Year Plan represents a major step forward in the planned development of new state industries.

4.2 The main pub11c sector 1ndustrial enterprises were 11sted in Chapter I, Table 1. The remalning public sector industries are relatively swall. There are about 6 significant ones, most featuring 1n the 11st of Tasadys which appears in Annex D. The most important public sector Industry is based on cotton: Afghan Text1les (three factorles); Bagrami Text1le and Balkh Text1le; Spinzar, Balkh and Belmond Cotton ginning and 011. Other major products are construction caterlals (Ghor1 Cement, and the prefabricated concrete plant), urea fert1llzer, and varlous food products. Locaticnally, most public sector 1ndustries are t1ed to the areas from which agricultural and other raw materials come. Some are In Kabul. Afghan Text1les' plants are midway between the ginning plants in the North and Kabul. Among the advantages of this resource-based locational structure of 1ndustry is that it has fac1litated exports to the USSR - notably of ginned cotton and urea. Quantitatively, hovever, Intersectoral linkages have been poor. A ajor aim of the Plan is to improve this situation.

4.3 As discussed in Chapter II, the Seven-Year Plan eavisages a substant1al expansion of public sector 1ndustry, with particular emphasis on projects linked to the agricultural and mineral sectors. In some cases such developments are planned as expansions of existing 1ndustrial undertakings. Most are, however, entirely new profects, many of them 1n areas were the 1ndustry concerned is not at present producing on a significant scale. These plans, even. If only partly implemented, would create problems of an entirely different magnttude to those which public sector industry now faces, and which are discrssed in this Chapter. Unless solut1cns to these problems are found and implemented, successful implementation of the planned public sector industrial profects may well be in jeopardy. 
The Contral of Public Sector Industries

4.4 There are four different types of public sector industry in Afghanistan: eaterprises that are parts of Ministries; Tasadys, government majorfty shareholdings; and majority shateholdings by organizations themselves under government control (possibly in conjunction with government's ow holdings). Even in the case of those vithin government $1 \mathrm{t}$ is not always clear into bat rategory particular enterprises fall, and the differences in government control procedures are often 1 ess marked in practice than they appear in principle.

4.5 The only 1mportant industrial enterprises which form part of a Hinistry, and operate as a branch of the goverment service, are the fertilizer factory and thermal power plant at Mazar-:-Sharif; these are part of the Ministry of Mines and Industry.

4.6 The largest group of public sector industrial enterprises are the Tasadys. Altogether there tare 41 of these at present, falling under 10 different ministries. They are 11sted in Annex D. All also report to the Ministry of Finance on budgets and accounts. However, onlv about 11 of these are clearly industrial enterprises, 10 of them under the Ministry of Mines and Industry, and one (the prefabricated housing unit factory) under the Ministry of Public Works. Six of the remainder are partly lndustrial in character: the Mint (Ministry of Finance); the Government publishing house (Ministry of Information and Culture); the educational publishing house (Ministry of Education); carpentry, stone and concrete-saking for the arzed forces (Ministry of National Defense); wood enterprises (Ministry of Commerce); and the Afghan Food Department (Ministry of Finance) of wich Kabul Silo, wich produces flour and bread, is part. Other Tasadys 1nclude mining and exploration, construction units, three port authorities, the domestic alrine, a cooperative for-issue of food coupons, the hotel industry, the department for firms in 11quidation, the government monopoly (sugar, o1l products, etc.), a film producer, an advertising agency, a press ciub, Nindaz (travelling shows), various medical and health insurance organizations, welfare and social organizations, and a slaughterhouse.

4.7 There are two 1nportant public sector companies, in wilch the government has a majority shareholding -- the Spinzar Company at Kunduz, - and Jangalak Industries. The largest single manufacturing company in Afghantstan -- Afghan Text1le -- is controlled by banks, whish thenselves, follouing nat Ionalization, have come under government contrcl. Afghan Textile, has, however, a large number of small private shareholders, and is icself the main majority shareholder in Spinzar and Jangalak.

4.8 As is evident from paragraph 4.6, the Tasady is a blanket fora of organization covering productive enterprises, service functions with government, and parastatal organizations of all types. Each Tasady is headed by an Arer-1-0muni (in practice the Minlster of the department concerned), who determines policy, approves annual plans and budgets, supervises the internal management of the Tasady, and appoints all except junfor staff. The Manageaent, headed by a President, is therefore on paper essentially the executive ara of 
the Amer-1-0mun.. I addition, there is a Buard of Jupervisors, draw.. from within government, whe rezort to the $A$-er-i-0muni and are supposed to c. ry cut b-monthly operational and financia! audits of the Tasady's affils.

- 9 In practice, however, Ministers arn uniole to devole is much time to the catailed critrol of Individual Iasadys is the job functions of the mer-1-0auni 1mply. The Board of Sup...visors frequently fatis arke the rt wired reports; Indeed in vieu of che lack of adequate accouncs $1 \mathrm{a}$ an; Tasadys, it is impossible for them to do so. Financial contrcl leads to be exerc1sed privarily by the Pres-ient of Tasadys in the Ministry of Fizance, but inth some Tasadys rears tahind in their subaissio. of accounts, and in view of the direct relationship between the Minister atd the Presidert of the individual enterprise, it is difficult for this cuntrol to be efiective.

4.10 In addition to the need for gove:nme-t appruval for a:l $L:-$ favestments, regular cuntr 1 over the eper i isns of industrial Trsadys is exercised in $1 \cdots, r$ main vays :

(3) Managemen:8 ire Kabla to make purchases of suppliss, spares, reflacemer. equipest, etc. in excess of, generally, detwe 1 Afs 200,000 and Afs $50 \mathrm{C}, 000$ (US\$, 500 to US $\$ 9,000$ ) wichrut the authority of the Minister responsible.

(b) The annual budgets (for all expe:diture items) har to be ipproved (see para. 4.11 below).

(c) Only suite funlor manarement appotstments lie within is discretion of ti.c Management.

(d) Prices and markups are in pirinciple fixed by the unister though ie ran delegate this power, in practice managements wel thenselves $t$ ted in their pricing policies.

Ministerial authorizations are often granted readily and rapit1y. - Un the szed

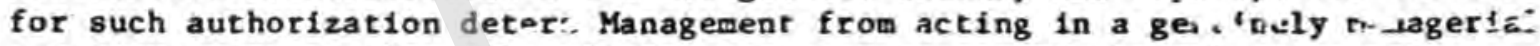
capacity; many of those the mission $t: t$ seem to regird themsei,es as not having any real responsibility elther for the 'mediate viability of the enterprise or for its long-term developaent. Whil 3 in princicte it apptars very reasonable that the government should conirol pricing pcifies, the practice in sone entecprisez has led to a rituation where $1=$ is impoesible to make profits on home market sales, without 1 t befng generally afprectated titat this 13 the case. The lack, f adequate ascounts often makes it difficuit co determine whether price increases art ceeded.

4.11 Each Tasady has tw budgets: an administrative budget for wages and overhead expenses curre iponds to what $t$. 1 iternal costs of a governent department would be; and an operating budget, co cover the cperating costs (1nciuding materials purchases) of the erterprise. Both budgets should be approved by the Minister responsitle for the incividual Fasady, thcuoh in practice this has been done by the budget depalcment of the finistry or 
Finance however, froc 1355 on, it no longer does this for operating budgets). Is arrive at the overall profits or Iosses of a Tasady, expenditure under the administrative budget is subtracted from cet livenue (total revenue less operating costs). The balance, if a profit, suould be transferred to the government, partly as tax and partly as a dividend. It should be noted, Doreover that:

(a) an amount equivalent to the annial depreciation provision 15 supposed to be deposited with the government's account to finance future investment speading. (In practice enterprises need this for working capital and they normally are allowed to retain most or all of it; socetimes, too, they don't transfer the whole of the profit).

(b) Tasadys are not nornally debited with service charges on loans.

(c) revenue for sales to government is of ten simply credited to the account of an enterprise, rather than being paid.

(d) as the administrative budget expenditure for Tasadys appears as an item of general government expenditure as vell as in the Tasady's budget, a consolidating adjustment has to be made to the transfers fron Tasadys to put the accounts into budgetary cerms.

4.12 The system of control of Tasadys may be appropriate to an organization of an essentially service or welfare nature, as many Tasadys are; but a potential higher management gap is opened up wen it is applied to productive industrial enterprises operating in a market environment. Ministers cannot devote the cime necessary to control operations in detall; senior officials in Ministries lack both authority and staff resources to do so, and some managements are either unwilling or incapable of performing effective management functions. In many cases, this potential gap is largely filled by the Minister (in practice) allowing more freedow of operation to managements than the Law of Tasadys implies; he approves managerent recommendations falrly automatically. But this does not always happen. An absence of detalled government control way well be advantageous, so long as the Eanagements assume true responsibility for the eaterprises" viability and long-term develcpment. At present, though, zven the best cannot or do not do this; and some seem only too keen to abdicate almost all responsibility.

4.13 The control of non-Tasady public sector industrial enterprises Eenerally differs in practice fron that applied to Tasadys in matter of degree and formal nechanism, rather than in were the true decisions are taken. This does not, however, apply to Afghan Textile. Because it has only recently come under government contral and its future status appears uncertain, and partly because it is so cuch larger and pore coplex an operation than other public 
sector industriat cnterprises, Af ghan Textlle remains in its day-to-day uperat: 2 s essentially what it was under private enterprise; government interve:tion, via the Board, appears to be $11 \mathrm{~m}$ ted to polfcy and long-tert atters. in other public enterprises with company status, though formally channelled through the Board, decisions on spending and pricing in the aain are tikon by the gorernent. Indecd, the government's responsibility is sonetizes as conplete as in any Tasady.

4.14 In spite of the syst 14 by which control is exercised at governeent rather than enterprise ic\%e!, public sector enterprises operating in the same industry work in the main as individual units, rather than as a coordinated gruup. This is tost obviously the case in cotton textiles, where public sector eaterprises are in direct competition for markets with one another, with private enterprise, and with imports. In principle, it might help efficlency for them to operate independently and in competition. But in practice the position is less than efficient. Some coordination is evident; but the real probleas will come with the creation of new industrial units. It is not clear whether these are to come under the managements of existing enterprises, or if encirely new enterprises are to be set up.

\section{Proffiability of Industrial Enterprises}

4.15 Though some Tasadys are several years behind in subaitting accounts, and though accounting procedures have several serlous deficlencies, $1 \mathrm{t}$ seems probabie that, overall, public sector industrial enterprises do cake profits. dmong Tasadys as a whole, some three-quarters are expected to have made profits in $1355(1976 / 77)$, though the concept of "profic" is somewhat artificial in relation to several of the non-industrial Tasadys included as "profitmakers". Of the enterprises visited, including non-Tasadys, the managements of all except one indicated that they had made profits in $1354(1975 / 76)$, or 1353 where 1354 internal accounts were not yet completed, and in most cases had been rade in previous years as well. Most of the1r estinates are bised on internal managenent accounting data; nevertheless, the total of estimated profits, less the one loss-maker, is around Afs 550 m1liton (US\$9.6 million) per annum.

4. 16 Many adjustments should be made to put such figures on a basis wich reflects core accurately the true position. The most important is loan service. So firm information on the total involved, both internal and external, could be obtained. On an arbitrary 8: of identifiable debt, probably around Afs 200 allition per annun should be subtracted from the profit figures quoted above. Other important adjustments may be necessary in the context of:

(a) depreciation rates (typically 6 to $8 z$ on nachinery and $2 \%$ on buildings) which take no account of inflation; and

(b) valuation of stocks (both raw materials and finished products) at historic values; this $1 \mathrm{~s}$ in some instances a less conservative procedure than night be assuned, as certain enterptises have significant unsaleable finished product stocks. 
issets are rarely, if ever, revalued, and it is scaetimes difficult even for the manageseat to check that stocks are artually held, as agafnst those shich exist on paper. This is a consequence of the systew, still common in Afghanistan, of the "bonded storekeeper", who in return for a personal bond has total responsiblity for the stores.

4.17 Tnough there was no opportunity to exanine in any detall the books and arrounting procedures of any publir sertor industrial enterprise in Afghanistan, it was rlear fron what the mission did see and its discussions with management that probably only 2 or 3 keep reasonably adequate financial and cost accounts. in others, procedures are rudimentary and nanagements are not very clear themselves shat is, or is not, included in "profit" figures. It seems quite likely that a core realistic overall annual pro?it figure for public sector industries might be in the area of Afs $250 \mathrm{million}$ (US\$4.6 million), which is quite suall. Much of this is by Afghan Textile. Because of non-revaluation of assets, it is not possible to relate any such figure to capital employed; indeed the distinctions between asse: value, original fnvestment, share value and loans outstanding are not generally appreciated.

Internal Vanagesent and Oserational Problens

4.18 The paragraphs wich follow note briefly some of the rost common and important problems found in the operations of the nine publis sectar industrial eaterprises visited by the mission. Deliberately, comments are not related to individual enterprises, as their inplications are general.

-19 It will be noted that most of the coments are not on technical asperts of the sperations of enterprises, or the use of the resources at their disposal. In general, the mission was quite impressed by the levels of romptence in these areas. The comments stem in the main from problems of planning (both before the enterprise was set up, and for its subsequent developnent), warket orientation, and rontrol (both within the enterprise and fron goverzment downard). It is these problems wirh, above all, must be solved if public sector industry is to achieve planned targets.

4.20 The largest single problem of Af ghanistan's publir sector Industry is its lack of management skills. Indeed, there is a widespread lack of understanding of the need to apply modern management srienres. This problem has been discussed in relation to both publis and private sectors in Chapter III, para, 3.3 to 3.10 . The $1 \mathrm{ark}$ of adequate arrounts noted in paras. 4.15 to +17 above is a major aspert of the problem; it deprives managements at one stroke of their most important single tool of analysis and control. Another ajor aspert, wirh emerges in the paragraphs which follow is the insufficient rrientatios of many enterprises to the market and the larik of any long-term flanning at the level of the enterprise.

..2: Related to the lark of aanagement skills is that of insuffirient telegation of responsibility. It impedes the developent of juntor and -iddle managesent into responsible senior exerutives. And it means that 
sentor managenent becones so involved in jinor patters of derail in furchases, contracts, staff appointments, ....) that it is unable to devote sufficleat time to strategic and long-ters matters. The problem is of course related to that of ministerial control of operations (paras. 4.6 to 4.13 ).

4.22 Of the nine enterprises visited only two were cperating at good levels of capacity utilization. In one case, the plant was still in the build-up phase. Two plants could not work at full capacity because of a lack of sufficient supplies of their main raw material, cotton, though their situation ta this respect has considerably improved in the recent past. In another, the nafn problez is a technical one, with a rav naterial whose quality is such that the plant has to be frequently closed for servicing; it also has problems with vater supply. In the renaining three, the main problen appears to be that of market insufficiency, in respect to either part or all of their operations, though technical problens exist as subsidiary reasons. However, in only one enterprise was overall capacity utilization below $50 z$, while in another three it was around 60\%. In general, levels of capacity utilization appear to have improved in recent years. Methods of calculating utilization vary considerably, and calculated rates should not be taken at face value.

4.23 It is worth noting that the plants affected by insufficient deand for their products are all old-established; it is not a question of wafting for demand to catch up with the capacity of a recently established project. Only one of them is actively seeking new markets for its output, and attempting to introduce new products to replace those for which denand is insufficient. Although one of the others has loag operated far below capacity, a doubling of capacity is planned.

4.24 A lack of awareness of market factors is widespread in public sector industry in Afghanistan, with the partial exception of cotton spinning and weaving. Managements rarely have any factually-based vieu of hou fast Afghani-stan's market for their products is likely to grow. In sone cases they appear to feel that it is up to government to assure them adequate markets. All the plants visited by the Mission, which were working below capacity mainly because of an insufficient warket, hive the technical capacity to ake products which could be sold to the private sector; only one of them has made any real atterpt to do so, and that on a limited scale. Indeed, apart from export sales to the USSR on terms negotiated by governnent, the great aafority of sales of public sector industry in Afghanistan, other than cotton textiles, are to governsent. In sone cases the nature of the sector zakes this unavoidable. In others, it does not.

4.25 In few of the enterprises is there evidence of management planaing to overcome current problens. In even fewer do potential new or long-term problems appear to be identified. Sor do nanagements appear to have devoted attention to devising plans, for subnission to government, for the long term development of the enterprise. Such questions are too frequently regarded as being far the government alone to consider. 
4.26 The problems of 1nsufficlent rav materials which have prevented the cottor ginning industry working at full capac1ty stemed from the insufficient inducement to farmers to grow cotton rather than wheat. Price Increases in 1352 and $1353(1973 / 74$ and 1974/75) have greatly 1mproved the supply situation, though this still falls short of ginning capacity. Further increases relative to wheat may well be needed if ginning capacity is doubled as the Plas envisages. (Th1s should not be taken as 1mplying that it 1s necessarily in Afghanistan's economic interest to bulld up cotton production at the expense of wheat).

4.27 In some Industries government price controls have created problems. The most important are cotton and cotton textiles; in these, low market prices have been held down to two-thirds or three-quarters of those realizable for exports. It was this situation which led to an export surge and the subsequent restriction on exports (see para. 3.24). In several other industries administered prices for hoøe market sales have pared down margins to th. point at which profits are very small even according to the enterprise's own accounts; if put on a more realist1c basis, they would be shown to be loss-making. (One example was an industry whose prices were linked to an assumed full capacity operation wich market insufficiency and technical problems make it impossible to even approach).

4. 28 At the technical level, as already noted, publ1c sector enterprises In Afghanistan seem to be reasonably vell-conceived, vel1-organized, and well run, though there are exceptions. A general tendency 18, however, poor manpower utilization. This exists to some extent in production problems (e.g. in terms of looms per worker); however, training needs and the implications of nodest vage rates explain this high labor utilization in part. The ratios of non-productive to productive staff are frequently very high. In some plants only around half the total manpower is directly involved in production process wth a quarter each in 'adninistration' and as aux1llary personnel (guards, gardeners, messengers, etc). And in several plants, only about two-thirds of the manpower vere direct production workers. In contrast, in one enterprise over three-quarters of total manpower is productive and under $5 \mathrm{z}$ is involved In administration; this small, high calibre, management staff was particularly efficient.

4.29 Afghanistan's geographical position and the 11mited level of industrial development to date zeans that individual enterprises cannot rely on assured supplies of imported materials and parts, and 4. other ways have to be largely self-sufficient. In particular:

(a) Dost enterprises have to hold eight month' to a year's supply of spares and chemicals and other imported materials used in the production process. This ofviously imposes a financing burden.

(b) Dost enterprises have established workshops to wake many parts themselves, as and when needed. These are equipped wth machine tools and other equipoent, and need to be staffed by skilled workers, yet use is only intermittent. 
Partly because of geographical dispersal, there is only limited scope for shared facilities of this type (though there probably is unnecessary duplication at present).

(c) In spite of the precautions noted in (a) and (b) above, 1ack of some quite simple spare part or imported rav material does on occasion delay production processes for months on end. It may be worthwile considering using air freight in such circumstances.

(d) most enterprises have established in-house training schemes for workers. These appear to have worked successfully; but they impose a significant cost on the enterprise.

(e) several enterprises have their own pover plants. Many have transport facilities for workers. And some have invested heavily in housing, medical care and other facilities normally provided by the State.

In general these arrangements appear to work reasonably well. All, however, involve costs to the enterprise which competitors in other countries are less likely to face.

\section{$\underline{\text { Recommendations }}$}

4. 30 Public sector enterprises should be freed from the system of control associated with the Law of Tasadys and be given the structural and organizatlonal seting in which they can operate with a greater degree of management responsibility and improve the efficiency of thefr operations. Under the general supervision of the relevant ministry under which they function (para. 4.6), public sector enterprises should have direct responsibilities for:

(a) management, supervision and coordination of plant operations;

(b) marketing;

(c) preparation of perfodic (monthly/quarterly) operational management information and annual financial accounts;

(d) financial management and profitability;

(e) staffing, except for chlef executives and directors;

(f) training of staff (1n lialson with the Ministry of Education and the proposed Managerent Development Center, para. 3.36).

4.31 Deta1ls of the future structural and organizational set-up of public sector industrial enterprises or groups of enterprises should be determined after careful study of the prevalling conditions in these industries in Afghanistan. No specif1c suggestions are, therefore, made in this report. One possibility, under consideration in the Ministry of Finance, which vould have to be assessed, envisages State Corporations, each covering a particular industry or group of industries. The principal objectives of reorganization, however, would be: 
(a) a ciear definftion of the responsibilities of enterprise level management and the controlling ministry respectively; and

(b) a substantial improvement in Inter-ministerial cooperation in matters affecting the functions of public sector fndustrial enterprises.

4.32 It is recognized that it would take some time for the current organization of public enterprises to be replaced by a new corporate systea that would give state industrial enterprises essential freedon from government control over day-to-day operations. In the meantime, the strongest possible pressure should be put on the managements of existing public sector enterprises to 1 mprove their accounting procedures and to submit their outstanding accounts for all years up to and including $135 \%(1975 / 76)$, as most are required to under the Law of Tasadys. Where it is not possible to submit accounts in the prescribed form, provisional accounts should be submitted. Particular attention should be devoted to problems of cost analysis and control, capacity utilization and pricing. It is recognized that only slou progress in these directions will be possible with the accounting and management skills which most enterprises now have. Paras. 3.36 to 3.38 contain recomendations for necessary improvement of managerial capabilities.

4.33 While emphasis should be placed on improving current accounting procedures rather than measuring past profits and losses, it is also 1mportant for revenue purposes to determine how much each enterprise is earning or losing. Given the accounting skills avallable, it will probably be easier to do this through a series of annual accounts prepared by the existing rather crude methods than by drawing up a full reconciliation including revaluation of assets.

4.34 Managements of existing public sector Industrial enterprises should also be urged to develop plans to put non-viable (parts of their) operations on a profitable basis where this is at all possible. Where losses result from government pricing policies, these should be specifically identified and covered by subventions.

4.35 Attention should finally be drawn to the importance for public sector industry of certain of the specific recommendations made in Chapter III, notably:

(a) the recommendation for rationalization of responsibilities

for industry (para. 3.33);

(b) the recommendation for the establishment of an Industrial Planning Unit (para. 3,34) and its suggested functions In the context of industrial coordination and project appraisal; and

(c) the recommendations to establish a Management Developsent Center (para. 3.36) to develop accounting services (para. 3.37), and possibly to establish management teams with external assistance for Individual (ot groups of) state enterprises (para. 3.38). 
V. PRIVATE SECTOR INIULSTRY

\section{Background and Present Status}

5.1 Despite the emergence of important public sector fndustries the bulk of Aghanistan's industrial employment continues to be provided within the private sector. Handicrafts and small-scale industries contribute more to employment, output and the export of inal industrial products than the organized industrial sector, both public and private. Employing about 300,000 persons, this segment of Afghanistan's industry continues to neet a significant proportion of domestic demand, supplying a wide range of consuner goods and construction materials. Handicraft products, above all carpets and rugs but also fur clothing, including pustinchas and posteens, embroidered textile products, leather goods, stonework, and jewelry are important export 1tems. Carpets and rugs alone accounted for US\$20 million or about 9 percent of Afghanistan's recorded exports in 1974/75. In addition, a considerable volume of carpets and rugs found their way through unofficial channels to neighboring Iran. Details of the recorded trade in handicraft iteas are shown in Anex A.

5.2 Production techniques in handicraft industries are simple and non-mechanized; they have barely changed for generations. Apart from carpets and rugs, the quality of handicraft items produced in Afghanistan is generally not very high. Otten labor-intensive work such as eabroldery is put into Inadequately prepared sheepskin roats and leather goods. Leather is poorly cured, kilns are too small for proper firing of pottery, and jewelry makers have no proper polishing equipment. Afghanistan has not yet improved its techniques of handicraft production. Consequently, in spite of low wage rosts Afghan handicraft products are often not coopetitive in export markets.

5.3 Being dispersed throughout the rountry, in probably more than 80,000 establishments, and lacking any form of association, handicrafts and small-scale industries are generally inelastic in volume and scope of production. These are determined either by the immediate local market they serve or the trader who in many instances provides produrtion materials and the operating capital needed. Kept within these bounds, management skills remain dt fairly low levels and any move into larger scale of production and the application of improvid techniques is generally precluded. It is evident that handictafts and small-scale industries have the potential to play a more signficant role in the development of the industrial sector than has been hitherto realized. There is considerable scope for technological improvement wile preserving traditional skills, organizing procurement of materials and equipment and better marketing of products. This, however, has as yet not been recognized by the government, and the support given to these artivities has renained marginal.

5.4 Private sector industry, other than handirrafts and small-srale industry, energed in Afghanistan prior to World War II but has developed on a broader srale only after 1967, mainly in response to the inrentives provided under the Foreign and Domestic Private Investnent Lav (FDPIL.). 
Although ractehensive information on this group of industries is not available, it is चderstood that the group currently compises about 130 establishments, wich together employ arounc 10,000 persons. Even take, as rough indicators, these data suggest that the average size of a private manufacturing enterprise in Afghanistan is rather large if compared to other countries at a similar stage of development. This feature would have been even aore pronounced had not several of the largest, originally private enterprises, such as the Afghan Textile Company and tie Spinzar Textile Company, rone under publir ownership (para. 4.1)

5.5 The partial list of industrial enterprises show in Table 1 shous five private sector companies, each with an employment of 200 or more persons. The largest, a skin pickling plant and a shoe factory (AHU) employed about 500 persons. The other four included a hosiery factory (Nowrozi) with about 300 employed persons, a pharmareutical plant (Hoechst) wth 250, and a plastics shoe factory (Watran) with about 200 employees. Two of these large private manufacturers had minority forefgn rapital participations.

5.6 The following chararteristirs appear to distinguish the private industrial establishments approved under the FDPIL until about m1d-1974 (for more details see Annex E):

(a) heavy concentration of import-substituting industries. With 72 out of 100 approved projects these industries accounted for 80 percent of the total original investment. The principal industry groups represented were rayon weaving ( 18 projects), plastic products including footwear (12 projects), and metal fabrication ( 8 projects).

(b) anong the 28 export-oriented industries the mcst important were leather and tanning ( 10 projects), raisin processing (9 projects), and animal casings ( 2 projects).

(c) about $86 \%$ of the to :al estimated original investment was concentrated in the Kabul area, with no other city participating with wore than $4 \%$ each.

(d) although there were 21 projects 1avolving forefgn investment, the total foreign investment was given as only Afs 312 million (USS5.5 million). There vere only two firms with substantial (minority) foreign capital participation. In the remaining 19 projerts approved, foreign investment averaged just Af 8 ail1ion (USS0.14 milition) per projert.

5.7 Since private industry establisted prior to 1967 is now relatively insignificant the above features are fairly representative for the private manufacturing sertor. Noreover, except for very saall industries, there are probabiy only few private manufarturing units that have no FDPIL status. 
5.8 Inforation on private industries that have begun operations since 1974 is very sianty. It is, however, olear that private industrial investment was adversely afferted by the uncertainties following the 1973 change in government and the lack of a rlearly defined policy tuward the private sector's role in industry. Arcording to the records of the Industrial Developent Bank of Afghanistan (IDBA) only 14 new industrlal profects have received final approval sinre 1974; of these, three are likely to be abandoned by the investors concerned and more may yet drop out. The total investment envisaged in all the approved projects would not exreed US\$10 million or about Afs 570 million.

5.9 The few entrepreneurs establishing projects under the FDPIL are people fror the trading class, with considerable knowledge of markets within Afghanistan and (to a limited extent) abroad, but with little knowledge of industry as such or of the wanagement skills it requires. Scme entrepreneurs are young, educated Afghans, who have previously worked in the publis sector and are seeking a more challenging and potentially more profitable outlet for their energies. But these are the exraptions. Or the whole, the small edurated segment of soclety prefers the greater security and status of government employment in spite of the meager levels of official salaries.

5.10 The lark of industrial tradition and direct experience has involved consilerable shortcomings in the development of private industries which has obviously contributed to discourage potential investors from new private industrial ventures. It is evident that a significant nuber of projects were misconceived. Sall enterprises using simple technology sought to coapete with larger operations able to produce at lower unit prices. The implications of simultaneously establishing a number of competing enterprises in the saze field were often cisregarded. Market research and project appraisal had rarely been undertaken before an industry was set up. As a result, enterprises found thenselves competing with cheaper imports, which in many cases were anyway favored over domestically produced items. All these are factors explaining the persistently low utili ation in manufacturing plants and the pile up of large stocks of unsold merchandise. Of the seven private firms the mission visited, two vere operating at only $20 z$ of capacity, and another two at around $50 z$. Some of the factories were carrying six-months' stocks of finished proiurts.

5.11 The faucity of management and techniral. skills or Indeed of any real urderstanding of the nature of the problems likely to arise in an industrial undertaking are probably the largest weaknesses of private sector industry in Afgtanistan, as also of most public sector enterprises. Although the private sector generally has a good grasp of desirable produrt characteristirs, and arceptabie prices, there is little appreriation of the need to determine how large the market is. There are also rases of terhniral defiriencies in producticn planning, and inappropriate marhinery. However, it should be stressed that the best private sector firms are stronger in these resperts than are the majority of publir sertor enterprises. 
Government Control and Support of Private Industry

Registration under the Comercial Law

5.12 Under the Commercial Law of 1334 (1954), every person who as an individual or as a member of a Corporation, possesses a legal comercial capacity and is engaged in one or more commercial activities is required to be registered. This Lav lays down provisions governing the conduct of commercial business by individuals, partnerships and by corporations. It regulates Commercial Documents and Commercial Agencies. The Chapter on Cospanies and Corporations contains the usual provisions regarding election of Directors and Board Supervisors of the Company by stockholders. However, reg1stration under the Commercial Law is probably far from comprehensive, in particular with respect to handicrafts and small industries.

\section{The FDPIL System}

5.13 In June 1974, the Government of Afghanistan pronulgated a new Forefgn and Domestic Private Investment Law in replacement of the old FDPIL of 1967. A sumary comparison of the major provisions of the old and tha new laws appears in Annex F. The main provisions of the 1974 FDPIL are:

(a) Four years" income tax holiday (six years outside Kabul) from the date of the "Final Approval" of a project;

(b) permanent exemption of duties on import of capital goods and a naximum $10 \%$ rate of duty on imports of spare parts (but full rates of duty apply to transport equipment, construction materials and office furniture);

(c) a maximum rate of duty on raw materials of $20 \%$ (in practice, however, many of the duties are set at under 10z);

(d) peraanent exemption from export taxes;

(e) exempion from certain direct taxes on capital and legal fees:

(f) after five years, profits may be renitted in annual installments of up to $20 z$ of the original investment;

(g) the share of fore1gn investment in the cotal cust not exceed $49 \%$;

(h) expropriation would be carried out only in the public interest, and after compensation, according to the pertinent legislation;

(h) Joverment departments and agencies are required to grant a 152 price preference over inports to FDPIL approved 1ndustries. 


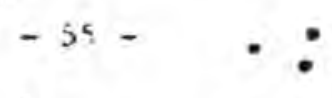

The limitation of foreign shareholdings to 492 creates potential problems In that it may be difficult for Afghan private interests to put up 512 of the capital requirement for any large project or indeed for a fair number of medium-sized ones. It is understood, hovever, that this rule may be wafved.

5.14 There is a two-stage procedure for approving applications under the FDPIL. The first involves submisston of a fairly simple form. The second requires a more elaborate application incorporating very detalled Information about the project and its impact on the economy. At each stage the application has to be approved by the Investment Committee, composed of the Ministers of Planning, Mines and Industry, Finance, Commerce, and Agriculture and Irrigation. Applications are submitted through the Private Investment Promotion Jepartment in the Ministry of Planning, which acts as a secretariat for the Investment Commitee. In practice the Private Investment Promotion Department has to guide and aid investors in completing their applications; IDBA also helps in this. The quite considerable changes in composition of Individual projects between preliminary approval and final approval stages (the majority of projects, particularly the smaller ones, are substantially expanded -- sometimes tripled or more -- in their stated investment requirements) may imply that this process is a useful one in permitting the only well-founded projects to come to fruition. On the other hand it probably sometimes means that the investor is persuaded to try and mount a project wich is beyond his management capabilities, and one which also requires new sources of finance.

5.15 It takes on average only about two months from the date of submission of the preliminary application to the final approval of the profect, which is quite satisfactory. There are, nevertheless, some weaknesses in the current procedural practice of the FDPIL system which should be remedied. One is ar. apparently built-in rigidity of the system to even minor changes in project characterlstics as described in the final approval. For example, one rayon weaving plant claimed it could not change the type of yarn imported under tariff concessions to another one required by changed market conditions without losing the relevant privileges. Another plant, a skin processing operation. claimed it could step up its exports beyond the level stated in the project approval, but would have to pay export duty. It seems that even such changes require separate approval of the Investment Committee.

5.16 Other problems are related to the competence of the Private Investment Promotion Department. While rather complex project data have to be provided by the potential investor, the Department appears 111-equipped to adequately assess these. It also appears that the role of the Department is percelved as being one of control of private industrial investment rather than to stimulate it and to promote new fnvestment.

5.17 Since the Private Investment Promotion Department does not usually accept applications involving investments of less than Afs 2 million, smallscale industry and handicrafts are in practice excluded from the benefits of the FDPIL system, although the FDPIL status is legally open to all industrles, regardless of size. 


\section{F1nancing and Other Ceceral Support}

5.18 intil a few years ago, there were only three banks in Afghanistan. Da Afghanistan Bank is the central bank and does not normally do any commerclal banking. Pashrany Tejaraty Bank is a government bank, wich provides financial assistance primarily for trading activities. Bank Mellie was started as a coumercial bank in 1930 but later moved into establishing large industrial ventures for which it acted as a holding company. Three nev banks have been established in recent years, namely, the Agriculture Development Bank (AgBank), the Industrial Development Bank of Afghanistan (IDBA), and the Mortgage and Construction Bank. All of these tanks became government owned under the Bank Nationalization Lav promulgated in May 1975. Operationally this nationalization is not yet fully effective and certain important features of the new arrangements have st1ll to be announced. In April 1976, the Government announced the decision to establish an Export Promotion Bank.

5.19 In the past the banks gave mainly short-tern comercial loans, and were not very active in providing finance for industry. The development of the private industrial sector in recent years has been financed mainly by the savirgs and accumulations of the Investors themselves, together with forelgn cap1tal and loans from foreign partners, suppliers' credits and to a limited extent, bank loans.

5.20 IDBA was founded in March 1973 with a share capital of 240 million Af 8 (US\$4.2 million), $60 z$ of which has been contributed by Afghan interests and $40 \%$ by IFC and five other foreign banks. In addition IDBA can drav on a credit of US $\$ 2$ million from IDA for providing a line of credit for private industry. The bank can provide loans to private industry for both fixed assets and working capital. It can also participate in the equity (and has in fact done so in the Yakoob Tannery Company along with Jenisco frow the USA). In practice, though, IDBA has not been able to provide any signiflcant financial assistance to private industry, as only a few new private sector incustries have been established since 1973.

5.21 IDBA's staff do, however, maintain regular contacts wth present and prospective investors in the private sector, helping them in appraising their financial requirements for existing and new projects, and seeking to Interest them in ut1lizing assistance avallable from IDBA. At the request of the Government of Afghanistan IDBA has also carried out some prefeasibllity studies, appraisals of projects, studies on customs tariffs, etc. With a view to identifying industrial opportunities, IDBA over a two-year period carried out preliminary investigation of more than 100 projects for possible investment in the private sector but no projects materialized as a result. In general, though, IDBA has been fairly successful in these ancillary activities and has established a core of mainly young Afghan staff with competence in these areas. In the absence of financing opportunities, the day-to-day activities of IDBA have thus taken on a management consulting character.

5.22 Apart from these activities of IDBA, and I1mited occasional advice on financial matters by other banks, there is a lack of institutional or significant private enterprise facilities from which private industry can get 
management ir technical support. There ire no adequate accountancy ifrms sperating is Afghanistan (ttough Cooper aud L gbrand are approved under the TDPIL they ate not at present operating,. Thero are no managemert consulting or research operatinas. However, 1 mited support on a personal contact ba: " was sometices gade available from within pitilir sector 'ndustry and the few prizate sector enterprises wth teclinical barkup facilities. Experts working within the public sector on technical assistanc. prograns also occasionai $y$ give inforal auvice to individual privote industrialists. .

\section{lndustrial Parks}

5. 33 Private sector industry in the Kabu: area is concertraced in a large industrial zone a few giles away from the cfry center. and it $1 \mathrm{~s}$ not in practice possible to acquire $I_{\text {ind }}$ and put $u_{t}$ an industrial building $\in 1^{-2}$ where in Kabul. Within this zone an Industrial Park is being establi.hed, with technical and financial aid from india. It is intended priarily for small and zedium-sized industries, and is at present the only such tacility in Afghanistan. A four-stage project is eventually envisaged within the Seven-Year Plan, as follows:

\begin{tabular}{|c|c|c|c|c|}
\hline Stage & Cospletion date & $\begin{array}{l}\text { Total area } \\
(\text {. meters) }\end{array}$ & $\begin{array}{l}\text { No. of } \\
\text { sheds }\end{array}$ & $\begin{array}{l}\text { No, of plots } \\
\text { without b?eds }\end{array}$ \\
\hline $\mathbf{I}$ & June 1976 & 88,750 & 10 & $1:$ \\
\hline I I & $J \cdot n=1976$ & 51,250 & - & 12 \\
\hline Expansion & March 1977 & 200,000 & - & 41 \\
\hline Later Dey. & March 1983 & 500,000 & $\cdots$ & $\cdots$ \\
\hline
\end{tabular}

5.24 Each shed is of 525 sy. meteco or a $2500 \mathrm{sq}$. Deter plot and well zonstructed. Th. unbuilt plots are ales of $25 \mathrm{C}$ sq. neters tach. Sites are servicid with electricity and water and there is to be a common facilities center, including machine tool facilities, foundry, laboratory, etc. There is, however, no $f$ ovision 'or sewerage or drainage. The pr'ce $i$. r purchase is about Afs $1.8 \mathrm{mflliton}$ for esch shed and Afs 55,000 for unbuilt plots; only a $10 Z$ downpayment is required, tis balance being paid over 13 years with a 2-year grace perioa, and bearing $6 z$ intere,t. Tis $\lrcorner$ ppeacs to be a little more than Afghan small industrialists are accustomed to pay for much inferior facilities.

5.25 Apart from co: rection of electricity and water, which is suld to be imminent, the park is ready for occupation. This nas apparently been the situation for about 2 years. The Industrial irea Development Authority, part of the Ministry of Mines and Irdustry, which is responsible for the fark, stated that they had receivcd 88 applicaitions for the first 24 vaca.cies (Stage I), and that applicants have been selected for all of these on the basis of citeria such as management competence, muivation, inport substitution, and new rathe: than relocated existing indust.ies. Dther sources suggested that there are only a few firn takers; this ipfors consistent with known progress of FDPIL final approvals. 
5.26 A proposa! to entrust the managesent of the Industrfal Park to an atonozous dutnority or Corporation is being considered by the Government, there are also proposals for setting up similar Industrial parks at Mazar-iStiarif, Herat and Kandahar; a preliminary report on these profects has been subaited by Indian experts to the Governent.

\section{Handirrates}

5.27 In spite of the $=$ =portanre of handicrafts in the eronony, clear poliries of zovernment to develop the sertor have been conspiruously larking. iractiral steps in support oz handirrdft produrtion have been ainiral and : alited to traditional export iters such as rarpets.

3.28 The main assistance which the handicrafts sector receives from Governent is in seruring export orders through the Export Procotion Departrent, establistied in the Miafstry of Congerce four years ago. It has been fiuite surressful in developing export markets for Afghan rarpets, and lorating frodurers tc exerute orders. It does not, however, prefinance export orders to allow an inrrease in outpur if foreiza deaand exreeds rurrent produrtion rapabilities.

5.24 The only other direct support to handicrafts is provided by the Afghan Handirrafts Prosotion Cenzer. This is a Publir Assoriation (Company) with a total share rapital of ffs. 2 million (US535,009), subscribed by the Ministry of Finance, tre Ministry of Connerre, the Ministry of Mines and Industr $\%$, the General Department of Civil Aviation and Tourisa, and the C-amber of Comerce and Indistries. While the rharter of artivities of this Center is quite vide and inrludes terhnical and conmercial assistance to producers, its present arilvity is confined to the managenent of the Afghan Hiadirraft seporfum. Indeed its very small rapital rlearly precludes it from doing aurh nore. The Exporiun was set up in Kabul by the Export Promotion Departzent in Derember 1975 for proaoting sales of handirraft produrts to the courist narket, Both produrers and traders leave p: odurts with it for sale. Prices are fixed by the Emporiun in ronsultation with them, and titey are ald when the produrts are sold. The Eaporium charges romaissions varying frow $6 z$ to $20 z$ depending on 1 tews concerned.

\section{The Future Role of Private Sector Industry}

3.30 Bpart fron the gereral and persistent problems of Afghan industry sirh as the rritical shortage of vanagerent skills, design and narketing rapabilities, there are a nimber of ronstraints that sperifirally affert triate industry.

5.31 The zost important of these coxstraints wirh has effertively cons:ibuted to retard private sertor artivities is the 1 ark of intention on the

art of the goverment to rlearly define what role private sector industry is - sperted to play in the rountry's eronomir developsent and to deteraine spreres of activities that wnid be available to the private entrepreneur. 
The absenre n? surh policy staterent rontinues to delay the restoration of onfidenre ate ,as rontributed tis a wisuspeat feel for in the private sector

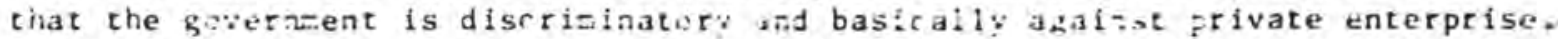
A!though rerent government st-tements do Indirate a more positive attitute to the private sector, it is neressary to take nore sperific neasures to generate ronfidenre. in addition to defining the artivities in wirh private sertor investments and operations wuld be felrone, the government would have to spell out and stress the guarantees it of fers against expropriation. Measures to redure or to waive current restrictions on foreign equity participation under the FDPIi. system would al so be condurive to restoring private sector confidence.

5.32 As is also reflected in the draft Seven-Year Plan, there is as yet no adequate offirial appreriation of the importance and potential of handicrafts and small-srale industry for the development of Afghanistan's eronosy. Inis izportant segnent of the Afghan economy should have a major role in industrial development strategy, and it is suggested that high priority be given to the establishment of effertive support facilities.

\section{Reromeendations}

5.33 It is suggested that in consultation with the Afghan Handirrafts Pronotion Center, IDBA and other concerned government agencies, an anpropriate iastiturfonal framework be developed to strengthen the rapabilities of the handirrats sector, with partirulat attention to the following areas:

(a) craining of handicrafts workers, to improve their skills, technologies employed, quality control and the suitability of produrts to market needs;

(b) training in bookkeeping procedures, and advice on financial and aanagenent problexs;

(c) partial Dechanization of produrtion processes, shere appropriate. Care will need to be exercised to rushion possible adverse esployment efferts and, where relevant, to =aintain "hand-maje" quality or status;

(d) testing farilities for raw saterials and finished and seci-finished produrts with a view to improving quality;

(e) organizing conmon proressing farllities for groups of produrers, where appropriate on a couperative basis -- e.g., bieaching and dying of yarn or woven fahrirs, rarpet washing, leather rhroming, kilns for reramies, etr:

(f) organiziag rooperatives tor purchasing, and/or garketing, were appropriate; 
(g) Earket research and development; establishing warket out lets in selected forelgn countries If the scale of potential orders justifles this;

(h) arranging flance on reasonable terms for machlnery and equipent and working capltal.

5.34 If the necessary support for handicrafts development is to be provided by the Afghan Handicrafts Promotion Center, Its capabllitles w11 have to be considerably strengthened. Alternatively, another agency may have to be developed to provide support for handicrafts in respect of functlons not covered by the Promotion Center. In any case, it may be approprlate to begin with a 1 imited number of pllot projects. An initial task would be to select and train key personnel for the various functlons. International assistance may be usefully employed for this purpose.

5.35 In paragraphs 3.36 to 3.38 the establishment In Afghanistan of a Management Development Center has been suggested. It is noted there that private sector industries should be encouraged to wake maximum use of these facilitles, and liaison with IDBA is suggested to this end. In addition, a management consultancy operation could with advantage be established to advise and assist Afghan private sector industry in:

(a) appralsal of Investment projects and preparation of FDPIL submissions;

(b) establishing and operating adequate costing, accounting, materlals managenent and inventory control functions;

(c) advising on financlal problems;

(d) selection of appropriate plant locations, production technlques and machinery, and advising on production problens;

(e) advising on procurement procedures;

(f) training of staff in appropriate skills;

(g) organizing aarketing, and continuing aarket research.

IDBA with its background, organization and experience, Is well suited to providing these consultancy services through a Consultancy Division. The potential conflict of interest argument is out weighed hy the success that IDBA has had in building up a nucleus of young tfghan staff copetent to carry out chese functions. Initially, services hay have to be provited iree of charge, or at nominat charges, implying I need for a subsidy fro the government. It wuld be necessiry to thech with IDBA what Additiond: strelga experts wuld he required ts estahlish such a panagesent consuitancy operation;

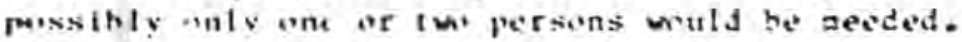


5.35 the systen of approving new rojects under the FDPIL should differeatiate between aajor enterprisez likely to have a slgaificant effect on the econoray, and lesser ones. Projects could be divided into two categor les:

Category $A$ : Projects with a total estimated investment in fixed assets including land, buflding, machinery and equipment of Afs 50 million $(\$ 900,000)$ or more.

Catezorv B: Projects with a total est imated investment in fixed assets including land, buildir.g, machinery and equipment of less than Afs 50 million.

5.37 For projects of Category A, the current two stage procedure of pre1 iminary approval and final approval may continue. For projects of Category $B$, a simplified form combining only the essential requirements of the present forms for preliminary approval and final approval should be used; and a one stage approval system would be more appropriate.

5.38 When a company wishes to effect changes in Its operations as against the terms of its original FDPIL submission (e.g., a change in raw material Inputs, or in the ratio of home market to export output), It should inform the Private Investment Promotion Department of this. If no objection is received within, say, 60 days, the change should be assumed to be acceptable. Only if the Department and the Investor are unable to agree, should the matter go to the Investment Connitree. The requirement that the maximum permissible forelgn shareholding is 497 shoula be formally withdraw, at least for larger projects, though possibly with provisions for offering shares to Afghan interests after, say, 10 years.

5.39 The Private Investment Promotion Department will need to be strengthened to deal effectively with the growing nuber of applications for private Investment which should materialize, If the recommendations of thls report are implemented. It should become mote pronotion- and development-oriented. When projects suitable for private industry have been identified by the proposed Industrial planning Unit (see paragraph 3.34). the Department should take the Initiative, together with IDBA, in seeking to establish these by alerting private interests in Afghanistan as to the potential and attracting appropriate foreign interests. 
Annex A: Trade in Industrial Product ${ }^{1 /}$

Exports from Afghanistan of Industrlal Products and Products For Processing Abroad In 1353 (1974/75)

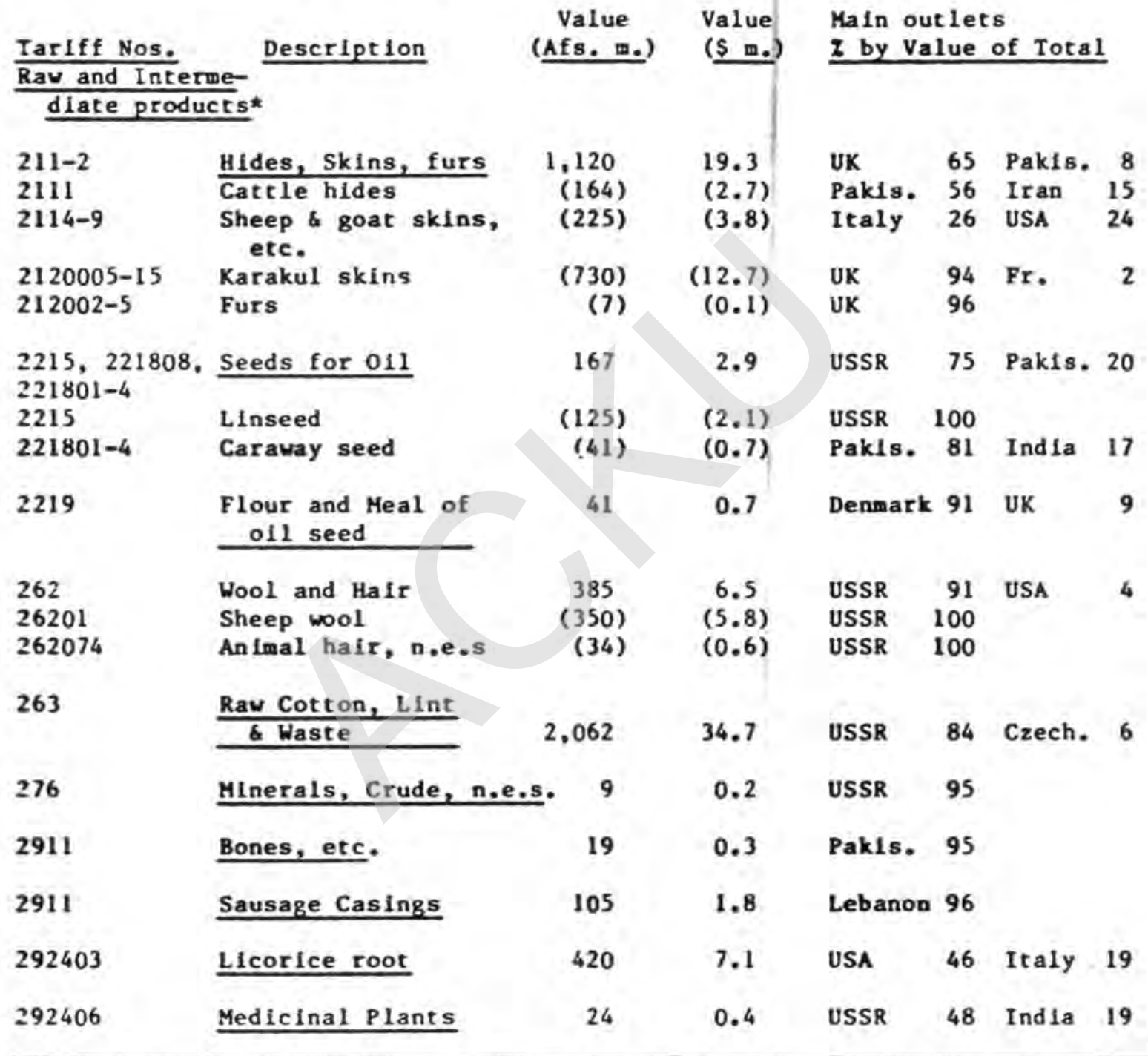

Total of above

$\underline{\underline{4,352}} \underline{\underline{73.9}}$

1) The figures in this Annex are officially described as provisional; data do not fully reflect the value of Afghanistan's external trade, and are shown here principally for lllustrative purposes. 


\begin{tabular}{|c|c|c|c|c|c|c|}
\hline $\begin{array}{l}\text { Tarlff Sos. } \\
\text { Final products }\end{array}$ & Description & $\begin{array}{l}\text { Value } \\
\text { fs.m.) }\end{array}$ & $\begin{array}{l}\text { Value } \\
\text { (s m. ) }\end{array}$ & $\begin{array}{l}\text { Ma1n outlets } \\
\text { Z by Value } 0\end{array}$ & of Total & \\
\hline $657501-2$ & Carpets & 1162 & 19.5 & Sw1tz. 42 & Germ. & 24 \\
\hline $657505-6$ & Rug 8 & 22 & 0.4 & Saud 1 A. 77 & USA & 7 \\
\hline 6612 & Cement & 105 & 1.8 & USSR & & \\
\hline 831 & $\begin{array}{l}\text { Handbags, wallets } \\
\text { purses, suftcases, etc. }\end{array}$ & 4 & 0.1 & Germ. & Neth1. & 18 \\
\hline $8411-84144$ & $\begin{array}{l}\text { Clothing (except froo } \\
\text { skins and furs) } \\
\end{array}$ & 6 & 0.1 & France & UK & 19 \\
\hline 84149 & Textile handicrafts & 46 & 0.8 & USA & $\mathbf{U x}$ & 18 \\
\hline 84201 & $\begin{array}{l}\text { Fur Clothing, 1ncl. } \\
\text { Pustinchas and Pustins }\end{array}$ & 52 & 0.9 & France 34 & Ux & 29 \\
\hline 89606 & Ant1ques, Various & 30 & 0.5 & Germany 42 & Surtz. & 11 \\
\hline $\begin{array}{l}\text { Misc. }(30 \\
\text { diff. nos.) }\end{array}$ & Other Manufacturers & 13 & 0.2 & & & \\
\hline Above & &, 440 & 26.2 & & & \\
\hline
\end{tabular}

* Products wich $1 t$ can be presumed w11 be processed abroad. Many other products may also be processed abroad (e.8.. In manufactured foodstuffs). 
Commercia! lmports into Afghanistan of Industrial Produrts in $1353 \quad(1974 / 75)$

\begin{tabular}{|c|c|c|c|c|c|c|c|}
\hline Tariff Sos. & Description & $\begin{array}{l}\text { Value } \\
\text { Afs.m.) }\end{array}$ & $\begin{array}{l}\text { Value } \\
(\mathrm{s} \mathrm{m.})\end{array}$ & $\begin{array}{l}\text { Main Su } \\
\text { Z by } \mathrm{Va} \\
\end{array}$ & $\begin{array}{l}\text { Suppli } \\
\text { Value }\end{array}$ & $\begin{array}{l}\text { ors } \\
\text { of Total }\end{array}$ & \\
\hline $\begin{array}{l}023,024,048 \\
062,073,099\end{array}$ & $\frac{\text { Food Products }}{\text { Confectionary, etc. }}$ & $\begin{array}{l}20 \\
(11)\end{array}$ & $\begin{array}{c}0.3 \\
(0.2)\end{array}$ & $\begin{array}{l}\text { USSR } \\
\text { USSR }\end{array}$ & $\begin{array}{l}60 \\
99\end{array}$ & Nethl. & 9 \\
\hline $\begin{array}{l}1123,1124 \\
121,122\end{array}$ & $\begin{array}{l}\text { Beer, Alcohol, Tobacco, } \\
\text { and products }\end{array}$ & 95 & 1.6 & USA & 64 & Pakis. & 28 \\
\hline 1222 & Cigarettes & (93) & $(1,6)$ & USA & 65 & Pakis. & 29 \\
\hline 2639 & $\begin{array}{l}\text { Cotton, Synthetic, } \\
\text { n.e.s. }\end{array}$ & 144 & 2.4 & UK & 51 & Japan & 49 \\
\hline 26701 & Used Clothing & 244 & 4.2 & USA & 45 & Nethl. & 21 \\
\hline $\begin{array}{l}332,3412 \\
3322\end{array}$ & $\frac{\text { Petroleum Products }}{\text { Kerosene, etr. }}$ & $\begin{array}{c}621 \\
(521)\end{array}$ & $\begin{array}{l}10.4 \\
(8.7)\end{array}$ & $\begin{array}{l}\text { Iran } \\
\text { Iran }\end{array}$ & $\begin{array}{l}82 \\
96\end{array}$ & UK & 6 \\
\hline 332502 & Lubricating oils & (89) & $(1.5)$ & UK & 39 & Nethl. & 21 \\
\hline 33261 & Petroleum felly & (8) & $(0.1)$ & Neth1. & 80 & Germ. & 12 \\
\hline 4310 & $\frac{\text { Animal Veg. olls, }}{\text { proressed }}$ & 399 & 6.7 & Nethl. & 32 & Sing. & 29 \\
\hline 5 & $\begin{array}{l}\text { Chemicals, and } \\
\text { Pharmareutirals }\end{array}$ & 826 & 14.0 & Germ. & 21 & Pakis. & 12 \\
\hline 5136 & Caustic Soda & (6) & $(0.1)$ & Germ. & 66 & Ind Ia & 27 \\
\hline $\begin{array}{l}5321 \\
5333\end{array}$ & $\begin{array}{l}\text { Dyeing extracts } \\
\text { Prepared paints }\end{array}$ & $\begin{array}{l}(45) \\
(20)\end{array}$ & $\begin{array}{l}(0.8) \\
(0.3)\end{array}$ & $\begin{array}{l}\text { Germ. } \\
\text { Pakis. }\end{array}$ & $\begin{array}{l}34 \\
66\end{array}$ & $\begin{array}{l}\text { Suitz. } \\
\text { Iran }\end{array}$ & $\begin{array}{l}16 \\
13\end{array}$ \\
\hline 5417 & Medícal preps. n.e.s & $(374)$ & $(6.4)$ & Switz. & 37 & Germ. & 25 \\
\hline $\begin{array}{l}553 \\
5541\end{array}$ & Toilet articles & (21) & $(0.3)$ & UK & 30 & H. Kong & 27 \\
\hline $\begin{array}{l}5541 \\
581\end{array}$ & $\begin{array}{l}\text { Soaps } \\
\text { Plastics and } \\
\text { produrts }\end{array}$ & $\begin{array}{r}(205) \\
(49)\end{array}$ & $\begin{array}{l}(3.5) \\
(0.9)\end{array}$ & $\begin{array}{l}\text { USSR } \\
\text { Japan }\end{array}$ & $\begin{array}{l}33 \\
51\end{array}$ & $\begin{array}{l}\text { Pakis. } \\
\text { Iran }\end{array}$ & $\begin{array}{l}31 \\
11\end{array}$ \\
\hline 5995 & $\begin{array}{l}\text { Prepared glues and } \\
\text { pouder }\end{array}$ & (5) & $(0.1)$ & Germ. & 38 & Italy & 20 \\
\hline 5997 & $\begin{array}{l}\text { Organic Chemical } \\
\text { products, n.e.s }\end{array}$ & $(18)$ & $(0.3)$ & USA & 92 & & \\
\hline 5999 & $\begin{array}{l}\text { Cheaical products, } \\
\text { n.e.s. }\end{array}$ & $(103)$ & $(1.7)$ & Germ. & 61 & $\operatorname{ts} A$ & 15 \\
\hline 61.62 & $\begin{array}{l}\text { Leather, rubber } \\
6 \text { Produrts } \\
\end{array}$ & 686 & 11.6 & Japan & 92 & & \\
\hline $\begin{array}{l}611 \\
6123\end{array}$ & $\begin{array}{l}\text { Leather } \\
\text { Prepared parts of }\end{array}$ & (9) & $(0.1)$ & Pakis. & 81 & Ind ia & 17 \\
\hline $\begin{array}{l}629101 \\
629102\end{array}$ & $\begin{array}{l}\text { footwear } \\
\text { Birycle tires \& } \\
\text { rubes }\end{array}$ & $(14)$ & $(0.1)$ & $\begin{array}{l}\text { Italy } \\
\text { India }\end{array}$ & 45 & $\begin{array}{l}\text { Iran } \\
\text { Japan }\end{array}$ & 35 \\
\hline
\end{tabular}




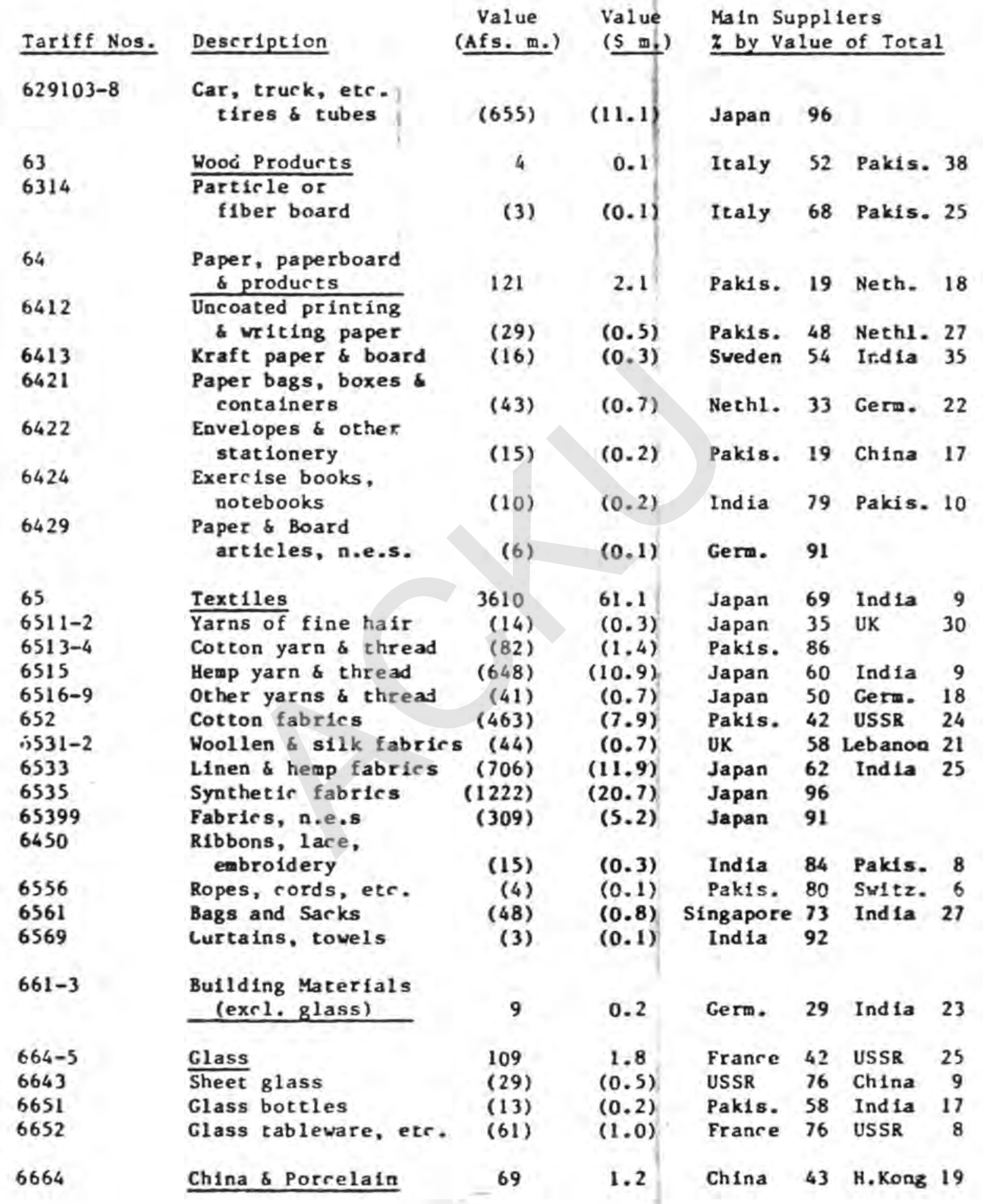




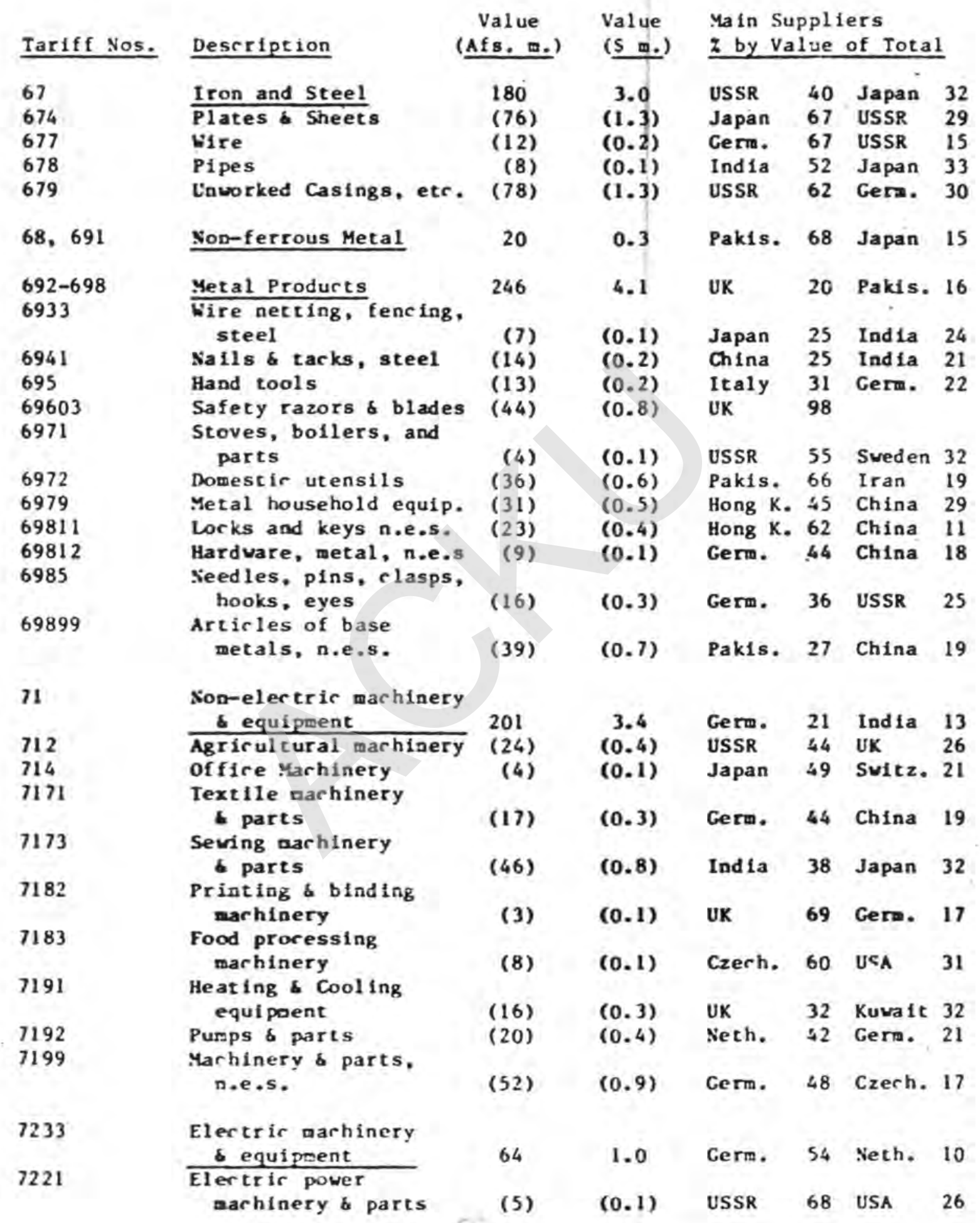




\begin{tabular}{|c|c|c|c|c|c|c|c|}
\hline Iariff Sos. & Description & $\begin{array}{l}\text { Value } \\
\text { fs. m.) }\end{array}$ & $\begin{array}{l}\text { Value } \\
\text { (s m.) }\end{array}$ & $\begin{array}{l}\text { Main S } \\
z \text { by } V\end{array}$ & $\begin{array}{l}\text { Suppli } \\
\text { Value }\end{array}$ & $\begin{array}{l}\text { ers } \\
\text { of Total }\end{array}$ & \\
\hline $\begin{array}{l}7231 \\
72329\end{array}$ & $\begin{array}{l}\text { Insulated wire } \\
\text { Electric equip. n.e.s }\end{array}$ & $\begin{array}{r}(4) \\
(46)\end{array}$ & $\begin{array}{l}(0.1) \\
(0.8)\end{array}$ & $\begin{array}{l}\text { Germ. } \\
\text { Germ. }\end{array}$ & $\begin{array}{l}63 \\
63\end{array}$ & $\begin{array}{l}\text { Ind 1a } \\
\text { Neth. }\end{array}$ & $\begin{array}{l}19 \\
13\end{array}$ \\
\hline $\begin{array}{l}724 \\
7242035 \\
724204 \\
72491\end{array}$ & $\begin{array}{l}\text { Radio \& Telephone } \\
\text { Equipment } \\
\text { Radio-tape recorders } \\
\text { Radio receivers, a.e.s. } \\
\text { Telephone equipaent }\end{array}$ & $\begin{array}{l}117 \\
(65) \\
(36) \\
(10)\end{array}$ & $\begin{array}{l}2.0 \\
(1.1) \\
(0.6) \\
(0.2)\end{array}$ & $\begin{array}{l}\text { Japan } \\
\text { Japan } \\
\text { Japan } \\
\text { Germ. }\end{array}$ & $\begin{array}{l}89 \\
97 \\
96 \\
85\end{array}$ & Germ. & 12 \\
\hline $\begin{array}{l}7256 \\
72501 \\
725052 \\
725056\end{array}$ & $\begin{array}{l}\text { Electric appliances } \\
\text { Refrigerators \& parts } \\
\text { Flat irons } \\
\text { Water heaters }\end{array}$ & $\begin{array}{l}39 \\
(14) \\
(7) \\
(7)\end{array}$ & $\begin{array}{l}0.6 \\
(0.2) \\
(0.1) \\
(0.1)\end{array}$ & $\begin{array}{l}\text { Germ. } \\
\text { Neth. } \\
\text { Japan } \\
\text { Germ. }\end{array}$ & $\begin{array}{l}30 \\
41 \\
37 \\
98\end{array}$ & $\begin{array}{l}\text { Neth. } \\
\text { Italy } \\
\text { B. Rong }\end{array}$ & $\begin{array}{l}19 \\
19 \\
22\end{array}$ \\
\hline $\begin{array}{l}7291 \\
72911 \\
729122\end{array}$ & $\begin{array}{l}\text { Batterles } \\
\text { Primary batteries } \\
\text { Storage batteries, } \\
\text { auto. }\end{array}$ & $\begin{array}{l}79 \\
(60) \\
(18)\end{array}$ & $\begin{array}{l}1.3 \\
(1.0) \\
(0.3)\end{array}$ & $\begin{array}{l}\text { Japan } \\
\text { Jap.: } \\
\text { Germ. }\end{array}$ & $\begin{array}{l}48 \\
62 \\
66\end{array}$ & $\begin{array}{l}\text { Germ. } \\
\text { H.Kong } \\
\text { UK }\end{array}$ & $\begin{array}{l}15 \\
15 \\
16\end{array}$ \\
\hline 7292 & Electric bulbs $\&$ tubes & 12 & 0.2 & USSR & 50 & Neth. & 18 \\
\hline $7295-9$ & $\begin{array}{l}\text { Other Electrical Mach- } \\
\text { inery \& Apparatus }\end{array}$ & 13 & 0.2 & Germ. & 71 & Iran & 11 \\
\hline 7321 & Passenger Vehicles & 64 & 1.1 & Germ. & 36 & Japan & 33 \\
\hline 7322 & Buses & 73 & 1.2 & Germ. & 94 & & \\
\hline $7323-5$ & $\begin{array}{l}\text { Lorries \& other } \\
\text { commercial vehicles }\end{array}$ & 161 & 2.6 & USSR & 62 & Japan & 16 \\
\hline 7328 & Motor vehicle parts & 270 & 4.6 & UK & 54 & Germ. & 10 \\
\hline 7329 & $\begin{array}{l}\text { Motorcycles \& parts, } \\
\text { etc. }\end{array}$ & 12 & 0.2 & Japan & 48 & Ind Ia & 20 \\
\hline $7331-5$ & Bicycles \& parts, etc. & 41 & 0.7 & Ind $\mathrm{fa}$ & 55 & UK & 14 \\
\hline $81-83$ & $\begin{array}{l}\text { Central heating appa- } \\
\text { ratus, lighting fix- } \\
\text { tures, mattresses, } \\
\text { furniture, suitrases, } \\
\text { etc. } \\
\text { Lighting fixtures } \delta\end{array}$ & 34 & 0.5 & Germ. & 58 & H. Kong & 27 \\
\hline 8124 & $\begin{array}{l}\text { Lighting fixtures } \delta \\
\text { parts }\end{array}$ & (29) & $(0.5)$ & Gerts. & 58 & H.Kong : & 28 \\
\hline
\end{tabular}




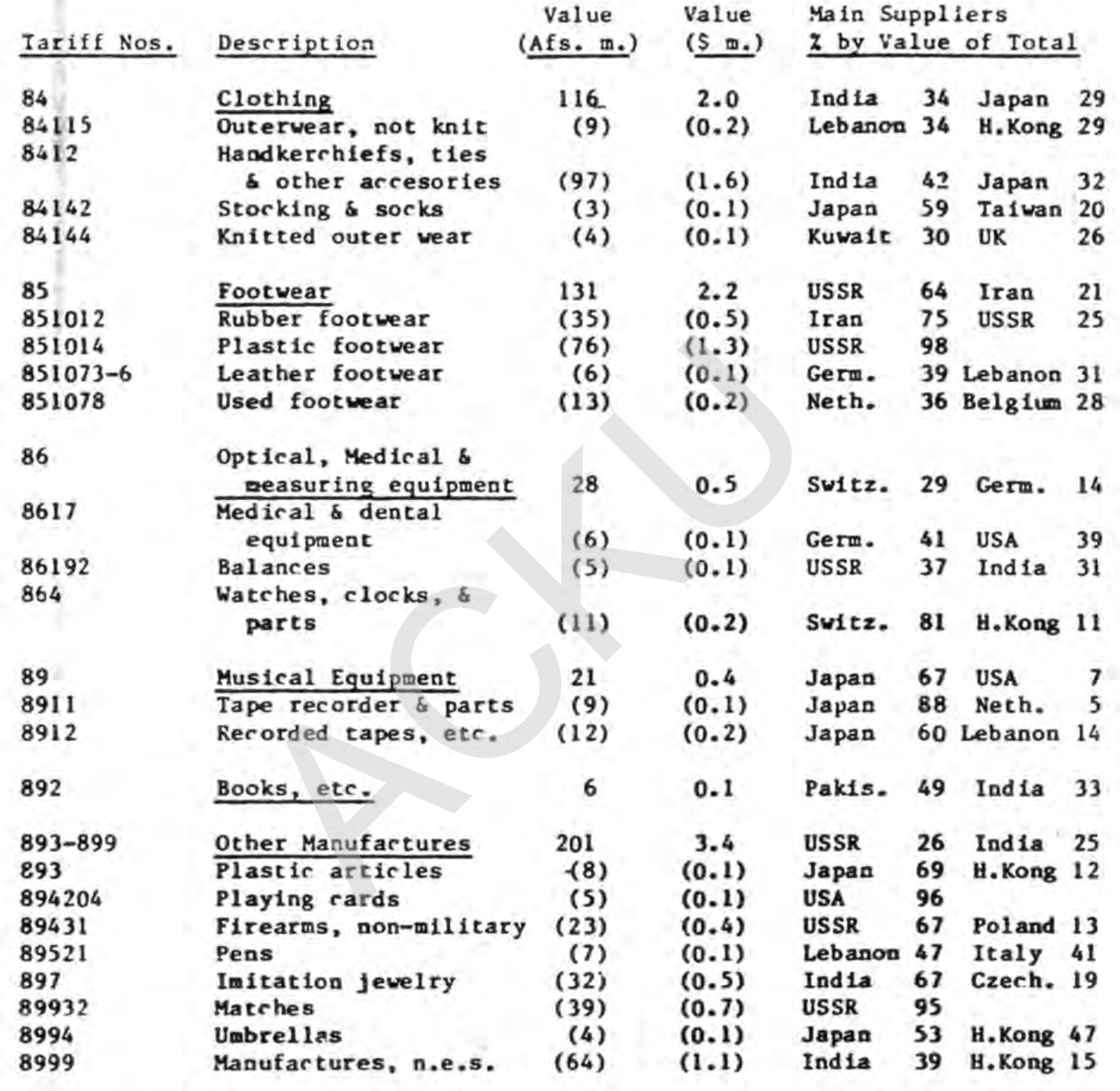

$\begin{array}{lll}\text { Total of romerrial imports } & 8,987 & 154.2\end{array}$

Monopoly imports 


\section{ANNEX A}

Tariff Nos. Description

Value Value Main Suppliers

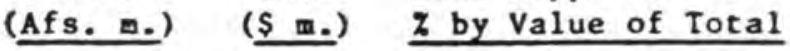

Loan or grant

finariced imports

431

554

561

931
Animal and Veg. Cil Soap

Fertilizers

Project Loan or grant imports $/ 1$
112

31

519

1110
1.9

0.5

8.8

18.7
USSR $\quad 100$

USSR 100

USSR 68 Saudi.A. 21

USSR 75 USA

Total of loan/grant imports

$1772 \quad 29.9$

All indistrial product imports

$11458 \quad 195.9$

11 assumed all are Industrial products - no breakdom avallable.

Source: Central Statistics office 
MANPOHER DEFICIENCIES IN PLBLIC SECTOR ENTERPRISES

1. A recent quantitative assessment of the zanpower situation in I6 public sector industrial enterprises by the UNIDO Industrial Services Project in the Minfstry of Mines and Industry suggests that existing needs and planned expansion (under the Seven-Year Plan) imply a requirement for the additional manpower as indicated in the table wich follows.

Additional Manpower Requirements of Public Sector Enterprises (nos.)

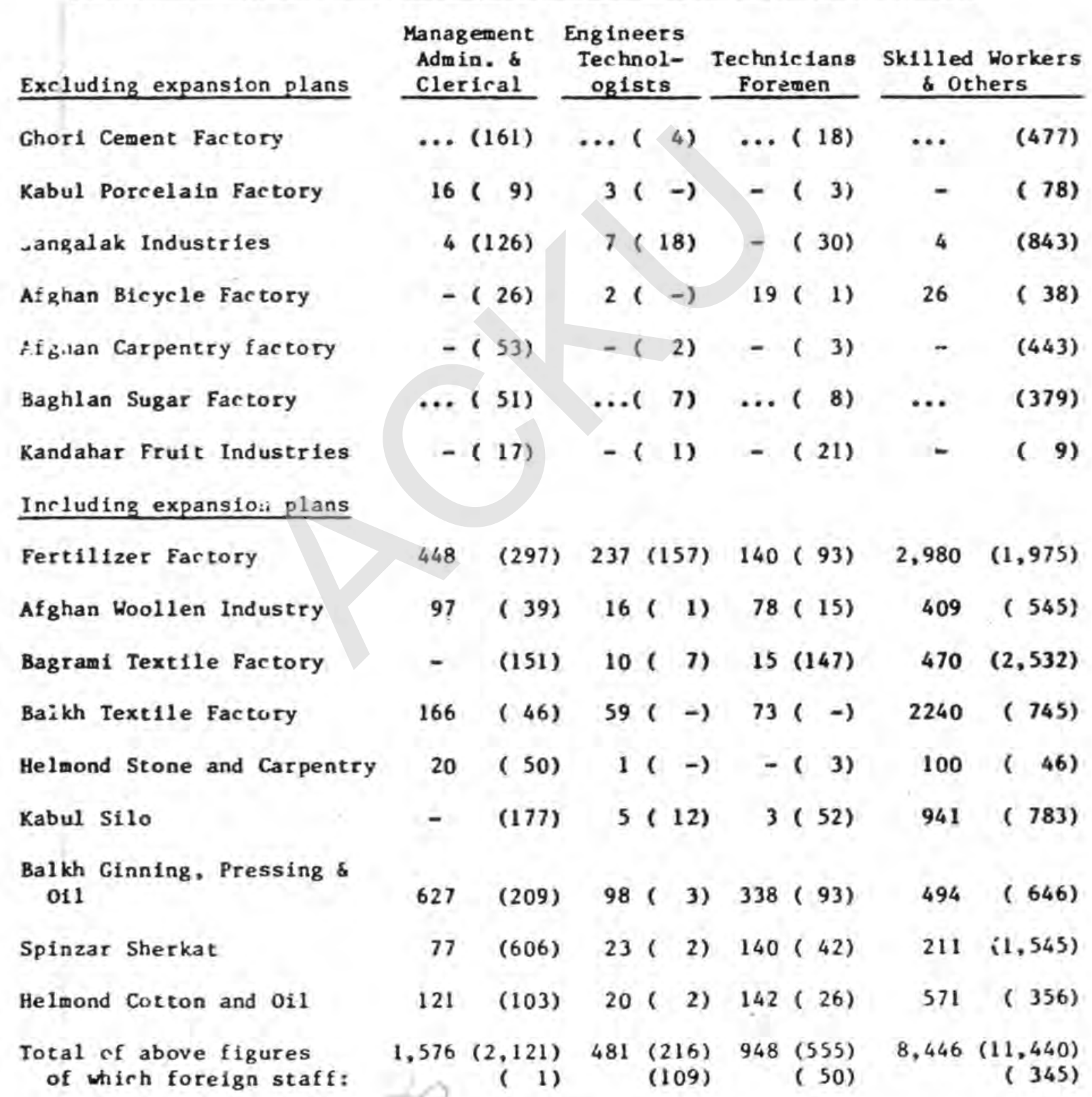

Note: Figures in brackets show existing employment

Source: Industrial Services Project, Ministry of Mines and Industry 
2. When the additional needs in this table ze pu: azalnst existing staff, large deficlencles emerge, particularly in respect $t$, the enginzerl technologist and the techniclan/foreman groups, and particular'y when ihe present number of foreign workers, notably in the furtilizer fact ry, 13 taken into account. Note, too, some obvious individual gaps: 4 os the enterprises have no engineers or tecnnologists at all; cne of these also lacks any technicians or foreman; and several necl to at least quafruple their staff in these categories. These nmerical deficitacies, particularly in the management and engineer groups, may be exaggerated. Note in particular the large indicated deficiencies relative tc existing staff at Palkh Ginning, Pressing and 0il, and at the Fertilizer Faztory.

3. The survey dia not arsess deficiencies in any qualitative sense. However, it is clear that:

(a) At both administrative/managerial and techical levels those in Afghan indusiry have rather inadequate formal skills; this prooably stims parti frow the defictencies of the general educational system in Afghanistan, and the fact that higher level education is frecuent:y in a foreiga language;

(b) The deficiencies are particularly marked tn canagement and administrative function 3 (in which craining facilities in Afghanistan are most who: 1y absent), notably in:

1) accounting, finatcial control and budgeting

11) marketing and warket research

111) forward planning and planning for new prodict lint3. 
PRESEST FACILITIES

IRAINING FOR INDCSTRIAL DEVELOPYEST

1. $\quad \therefore$ preseat :4 different institutions in Afghanistan give iraining relevazt to isdusti ial developoent. Only four of these give degree level rourses. Theg are:

(a) The Kabul Infversfty, Farulty of Eronom1cs, with gives a $t_{-\rightarrow}$ year first degree level course; in !323 there vere 66 graduates from =his;

(b) The Kabul Iniverstty, Farulty of Engineeriag, which gives a 5-year first degree level course. In 135: the intake was of about 200 students: 125 of total enro:lent that year was in electrical or mechaniral engineerits:

(r) Katu: Polytechnic (Kabul Unfversity), which gives a 5-year first dezree level rourse; it had 148 final-year students in 1353, of witch 11 were studying chemical technology;

(d) Institute of Industrial Managene:.t's four-year management rourse has an annul output of $50-50$ students; it is a zeretal rourse, at rather belcw unveristy first degree Level.

The rezaizing iastitutions are essentially of technical high sehool level; typirally takigg eight to nigth grade students for three to four-year courses. T.eir roebined annual incake is around 1,350 students. About 350 of these are taking cxperfial courses appropriate to upper grade clerical fobs. Yost of the reaafader are taing courses wich would sult thea to terhnical posts in indus. $r$, tatcer than engineer or technologist positfons, though some go on so take deztee courses at one of the institutions Ifsted above.

2. It stould be noted that though staple bookkeepting does fearure as a quite =far part of sone of the rourses at rechniral college or techalcal $\because \mathrm{gh}$ setoon level, and arcounting subjerts also feature in mfnor roles in the Farulty of Ercnonirs and the Institute of Indistrial Managenent's rourses. there aze no rourses with devote suffirlent attention to these subjerts to atvel =p asequate bookkepers of cnct arrnuntass. let alone auditors, or senior inanrial fatazcent. The defirtescles th the other zanagesent srleartes are usily silztitly less narked.

2. The destec-level rourses do not procure graduates of a particularly

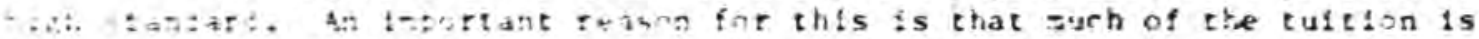

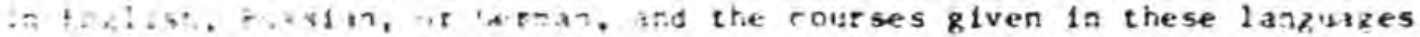

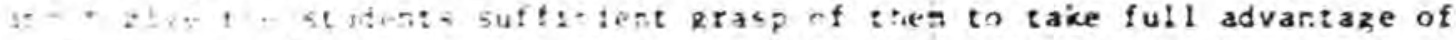

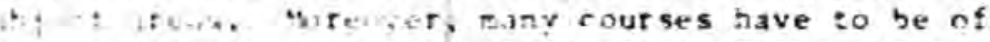

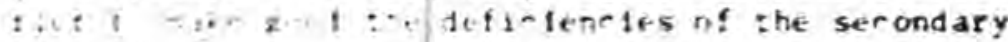


eduration systes. Both numers of qualiflec and sultable students and tearhing facllities are inadequate to offer second degree courses, and these have to be take= abroad; it is probatiy more difficult for Afghans to take full advantage of education abrcad than nationals of any other developing countries because the lan'sge barrier is greater.

4. There are no formalized facllities for enabling those wth one or more degrees to develop additional skills once in full-time employment, though soae enployers do offer in-house scheaes aad the ILo profect is proposing management development courses. Courses are urgently needed to equip existing as vell as potential industrial managements at all levels with the aajor tools of modern managezent science - accountancy, financial planning, warketing, Investment appraisal, qualicy rontrol, stock control, etr.

5. The expansion planned in training farilities obviously needs to be 1 inked to the planned development of Ind'vidua! sectors of the econony. however, past assessments which have been carrled out on the demand for partirular types of expertise, show big variations. Much more work is needed ia this area.

6. Sose of the techniral training facilities avallable in Afghanistan are not befag fully ut 111 zed. The reasons for this are not very clear, but are probably at least partly notivational, reflecting the not very high status of te technical professionals in Af ghanistan. It is rlearly necessiry to ensure that wriking in industry, wether as an engineer, a technirian, an accountast or a manager is sufficiently attrartive. 


\section{A. Ministry of Mines \& Industry}

1. National Oil Company

2. Afghan Mobil Carpentry

3. Balkh Ginning, Pressing and 011 Extraction

4. Coal Industry and Cosl Brickets

5. Kandahar Fruit Industries

6. Balkh Textile

7. Bagrani Textile

8. Woollen Industry, Puli-Chakr 1

9. Afghan Bicycle (current products: ceramics, glass and plastics)

10. Helmond Cotton \& Vegetable Oil

11. Chori Cemeat

12. Helmond Stone Cutting \& Carpentry

B. Ministry of Finance

1. Civil Service Cooperative (food eoupons, etc.)

2. Liquidation Dept. (firms in liquidation)

3. Hotel Industry

4. Government Monopoly (sugar and petroleum)

5. Afghan Food Department (Kabul Silo is part of this)

6. The Mint

C. Ministry of Information and Culture

1. Afghan Show Business (sindaz)

2. Af ghan Film

3. Government Printing House

4. Afghan Advertising Azency

5. Afghan Press Club

D. Ministry of Publir Health

1. Malaria In, ection Institute

2. Blood Bank

3. Civil Servire Insurance

4. Ceneral Meoiral Depot

E. Ministry of Publir Works

1. Pre-fabrirated Conrrete Planz

2. Afghan Construrtion tinit (Kabul)

3. Banaiy Construrtion

4. Wazer Supply and Canalization Enterprise 
F. Ministry of Comerce

1. Wood Enterprises

2. Port Authority, Turghard1

3. Port Authority, Hafratan

4. Port Autbority, Shirkhan

G. Ministry of Education

1. Afghan Wowen's Sorlety

2. Educational Press

H. Ministry of Defense

1. Carpentry, Stone and Concrete-making Enterprises

2. Kabul Slaughterhouse

I. Ministry of Justice

1. Rel1gious Trust

J. Afghan Afr Authority and Tourfse

1. Bakhtan Arline 


\section{PRIVATE INDSUTRIAL PROJECTS ESTABLISHED UNDER FDPIL}

\section{BY TYIF: OF INIUSTRY}

\section{Orlented tuwards Domest ic Market}

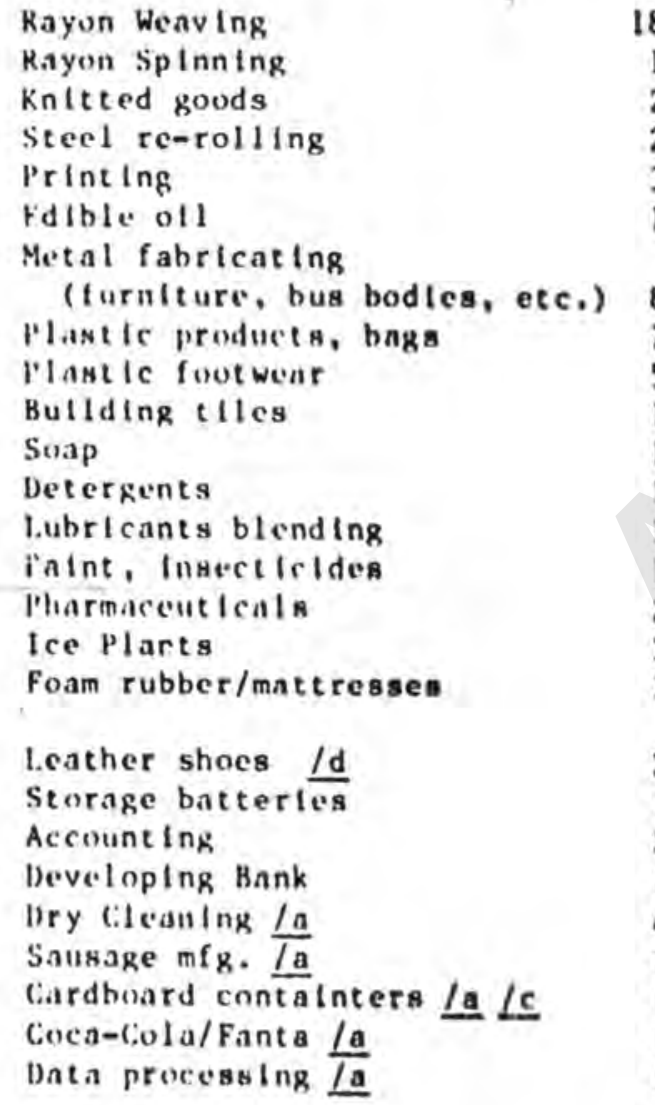

Export-ortented

$\begin{array}{lr}\text { Anlmal Casings } / \mathrm{b} & 2 \\ \text { Ralsin processing } & 9 \\ \text { Leather and tanning } & 10 \\ \text { Honey processing } & 2 \\ \text { Bone meal } & 1 \\ \text { Fur raising and processing } & 1 \\ \text { WIne making } & 1 \\ \text { Nut processing } & 2 \\ & - \\ \text { Total } & 28\end{array}$

Note: of the total $100 \mathrm{ftrms}, 6$ were temporarlly closed, and 5 were ready to operate, though not actually dolng no.

la much of the output or servlces of these firms are sold to forelgners in Af ghanistan.

Lb excludes 3 lenther f I rms also export Ing casings (counted under leather)

Lc eventually included as exports (packagea ralsins)

$\angle d$ the largest of these firms is also a major exporter of skins

Source: Checchl Report, September, 1974 
PRIVATE: INDUSTRIAI. PROJECTS ESTABLISHED UNDER FDPIL

HASIC STATISTIC:S (aII f I guren rominded)

\begin{tabular}{|c|c|c|c|c|c|c|c|c|c|c|}
\hline Type of Project & Total & & \multicolumn{4}{|c|}{ Export Market-0riented } & \multicolumn{4}{|c|}{ Domest lc Market Oriented } \\
\hline Number of projects & 100 & & \multicolumn{4}{|c|}{26} & \multicolumn{4}{|c|}{72} \\
\hline $\begin{array}{l}\text { Est Imated Investment la } \\
\text { (millitons of Af } \mathrm{s.})\end{array}$ & 1,204 & & \multicolumn{4}{|c|}{236} & \multicolumn{4}{|c|}{968} \\
\hline Percent of Inverstment & 100 & & \multicolumn{4}{|c|}{20} & \multicolumn{4}{|c|}{80} \\
\hline Geographlc Location & Kabul & Jalalabad & Mazar & \multicolumn{3}{|c|}{ Kandahar } & erat & Charlkar & \multicolumn{2}{|c|}{ Aqucha } \\
\hline Number of profects & 82 & 4 & 3 & \multicolumn{3}{|c|}{6} & 2 & 2 & \multicolumn{2}{|r|}{1} \\
\hline $\begin{array}{l}\text { Est Imated finvestment } \\
(\mathrm{mill} \text { ilons of Afs.) }\end{array}$ & 1,037 & 48 & 16 & \multicolumn{3}{|c|}{41} & 27 & 15 & \multicolumn{2}{|r|}{20} \\
\hline Percent of Investment & 86 & 4 & 1 & & 3 & & 2 & 1 & \multicolumn{2}{|r|}{2} \\
\hline Nac ivin: : :y of Investment $/ \mathrm{b}$ & Afshanlstan & Pakistan & Ind Ia & USA & $\underline{\mathrm{UK}}$ & Germany & $\underline{5 w 188}$ & Italy & Iran & Turkey \\
\hline Number of projects $\underline{\text { lc }}$ & 92 & 7 & 3 & 3 & 2 & 2 & 1 & 1 & 1 & 1 \\
\hline $\begin{array}{l}\text { Est Imated Investment } \\
(\mathrm{mil} \text { ll lons of } \Lambda \mathrm{fs})\end{array}$ & 892 & 69 & 10 & 38 & 15 & 128 & 35 & 5 & 2 & 10 \\
\hline Percent of Investment & 74 & 6 & 1 & 3 & 1 & 11 & 3 & 0 & 0 & 1 \\
\hline
\end{tabular}

1a Fixcluding IDBA, Hayat, Akary and projects under construction. Includes Af s. 15 mflllon for AHU Show under exports since the company exports leather as well as maklng shoes for the domestic market.

Lh According to Eilptl. applications.

Lc Projects with any forelgn Investment are counted under the forelgn country as well as Afghanlstan. For value of Investment figures, the percentage of Investment from each country is used.

Source: Checchl Report, September 1974 


\section{COMPARISON OF}

\section{AND 1974 TOREIGN AND DOMESTIC PRIVATE INVESTMENT L.AWS}

\section{FDPIL $1345(1967)$}

$\wedge \mathrm{Im}$

Type of Industry qual If y Ins

$\therefore$
To encourage and protect new prlvate Investment by both forelgn and $\mathrm{Afghan}$ nat lonals so as to promote economlc developinent and to advance the standard of living in Afghanlstan.

All new private Investments in any of thene fleldn of activfty: (a) Induntry; (b) mineral exploltations (c) ngrlculture: antmal husbandry or the processing of agricultural or animal products;

(d) tourlsm; (c) any service Industry or prlorlty enterprlse not included in the above categorles whlch the Investment Committce may designate by regulation pursuant to thls law.

\author{
FDPIL 1353 (1974)
}

To encourage, protect, gulde and control private Investment for the creation and expanston of Industrles, and to provide necessary collaboration between public and private Investment for the purpose of the progress, coordination, and balanced development of the natlonal economy.

Those based on:

(a) maximum uso of Af ghan raw materlalw;

(b) maxlmum use of Alghan manpower:

(c) Import substitution;

(d) Increase in quallty and value of exports;

(e) sat Isfaction of the consumer needs;

(f) use of Af ghan Industrlal products;

(8) maxtmum value added. 
FDPIL $1345(1967)$

Beneftts (a) Exemption from taxes on income for flve years.

(b) Exemption from Import dutles on capital goods, for flve years beginning the date of approval.

(c) Exemption from Import dutles on replacement parts for flve years.

(d) Exemption from Import dut les on raw materials of semi-f Inlshed goods for flve years.

(c) No Import duty exemption on passenger automoblles.

(f) lixemption from taxes on dividends for flve years from the year in whlch a divident is first declared, privided that It shall in no event extend beyond elght years from the date of FD'IL approval.

(g) Exemption of all export dutles for ten years from the date of approval of the Investment.

(h) Speclal benef Its outslde Kabul.

(1) No exemption from sukuk (a tax on capitel) and other levles.

\section{FDPIL 1353 (1974)}

(a) Exemption from taxes on income for four years only,

(b) Capltal goods exempted (In accordance with Article 26 of the Customs Law) with no t Ime 1 imitation.

(c) Ten percent duty (on the basts of the Involce or the unlt price) on replacement parts with no time 1 imltation.

(d) Maximum twenty percent duty on raw materlals with no time IImitation. Detalled schedule provldes many dutles in 5-10 percent range.

(e) No Import duty exemption on passenger automoblles, trucks, construction materfal and offlce furntture.

(f) This is for tour years and in no event will it extend beyond seven years from the date of approval.

(B) No time 11 imitation on export tax exemption, provided that the products are permitted to be exported.

(h) :'r projects outside Kabul, exemptlons from Income taxes and taxes on dividends are increased by two years.

(1) Exemption from payment of some, but not all, sukuk taxes, reglstration fees, and other legal fees levled by the court in connection with documents and deeds. Flxed court servlce fees. 
FDPIL 1345 (1967)

Repatrlation of proflts, Interest. capltal and salaries

Right to dispose nf shares

Agreements concluded by the Inveratment Comm letec

Jolnt ventures total. Afghantstan Bank. investor. (a) Reglstered forelgn capltal and such relnvested profits may not be repatrlated after five years at an annual rate not to exceed 25 percent of the Investment.

(b) Repatriation of salarles up to $70 \%$ of

(a) Shares may be sold to any Afghan or foreign national but not to any foreign government or agency.

(b) The proceeds of the sale of shares can be transferred abroad through $\mathrm{Da}$

Separate arrangements on the sale of shares, management contracts, capacity, tralning, can be made between the Investment Commlttee and the forelgn

Its encouragement is among the objectives. No 1 imitation of foreign equity.
FDPIL 1353 (1974)

(a) Such forelgn capital may be repatrlated after flve years at an annual rate not to exeed 20 percent.

(b) Up to 60 percent of salartes may be repatrlated.

(a) The same with the limitation that the sale of shares to forelgn Investors cannot exceed 40 percent of the total.

(b) The same.

No provision of this sort unless the procedures for establishing regulat lons and administering the law set up according to Article 20.

The share of forelgn Investment cannot exceed 49 percent. 


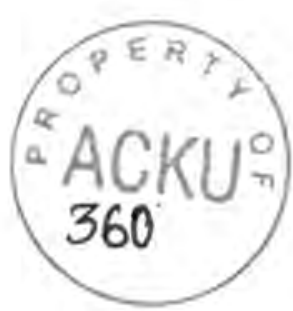

FDP1L 1345 (1967)

\section{$\frac{\text { ANNEX }-F}{\text { Page } 4}$}

FDPIL 1353 (1974)

\section{Government purchase of} local products

Exproprlation

Speclal

agreements

\section{Abrogation of former law and retroactivity}

All goverument agencles and departments are required to purchase from enterprises under this law, provided that they are similar in quality and price with importable equivalents.

Property is protected against government exproprlation (Article 29 of the Const (tution).

In the fleld of mineral exploitation or basic Industry, whether forelgn or domestic investors, wh greater or lesser benef 1 ts or obligatlons are allowed.

Repealed (a) the Forelgn Investment Law, and (b) the Law Encouraging Indsutries. Foreign Investments made under the FIL of 1958, the legal rovisions applicable thereto shall continue until they expire.
The same provlded that the price of the local goods and services shall not be more than fifteen percent $h / g h e r$ than Importable equivalents.

Expropriation can be carried out only in the public Interest and after compensation made according to the law.

No equivalent provisions.

W111 be controlled by the Investment Commlttee. In case of proof that an Investor abuses the exemptions and prerogatives, the Investment Commlttee has the authority to withdraw these benefits partially or entirely. 